I N T ER N ATIONAL MONETARY FUND

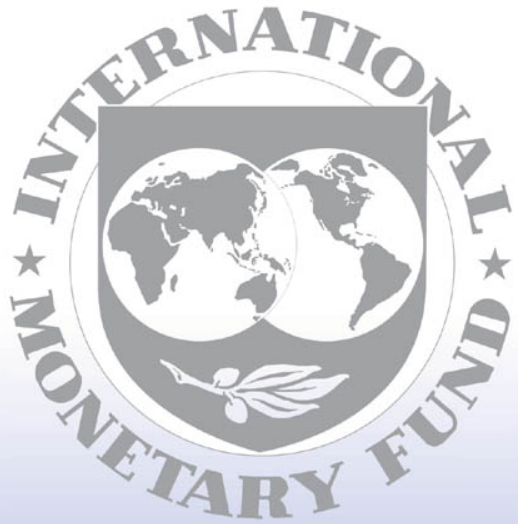

Staff

Country

Reports 


\section{Republic of Poland: Selected Issues}

This Selected Issues paper for the Republic of Poland was prepared by a staff team of the International Monetary Fund as background documentation for the periodic consultation with the member country. It is based on the information available at the time it was completed on March 25, 2008. The views expressed in this document are those of the staff team and do not necessarily reflect the views of the government of the Republic of Poland or the Executive Board of the IMF.

The policy of publication of staff reports and other documents by the IMF allows for the deletion of market-sensitive information.

Copies of this report are available to the public from

International Monetary Fund $\bullet$ Publication Services

700 19th Street, N.W. • Washington, D.C. 20431

Telephone: (202) 6237430 • Telefax: (202) 6237201

E-mail: publications@imf.org • Internet: http://www.imf.org

Price: $\$ 18.00$ a copy

\section{International Monetary Fund Washington, D.C.}


This page intentionally left blank

CInternational Monetary Fund. Not for Redistribution 


\section{INTERNATIONAL MONETARY FUND}

\section{REPUBLIC OF POLAND}

\section{Selected Issues \\ Prepared by Céline Allard and Anthony Annett (EUR) \\ Approved by the European Department}

March 25, 2008

Contents

I. Macroeconomic Effects of EU Transfers in New Member States.................................

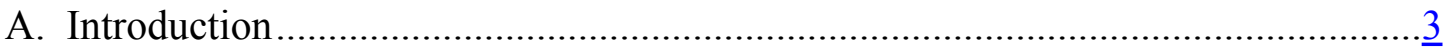

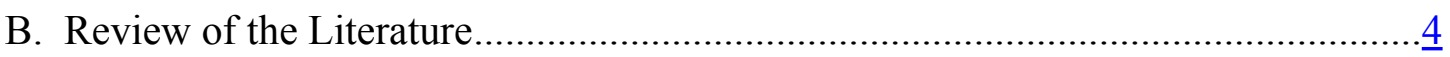

C. Modeling the Effects of EU Transfers to Converging NMS Economies................. 7

D. Simulation Results and Lessons for Policymakers ................................................11

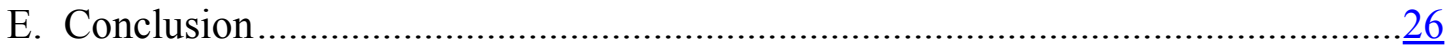

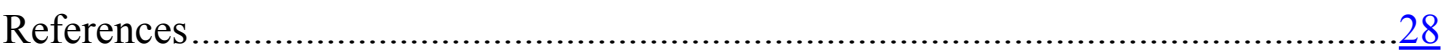

Figures

I.1. Convergence Scenario (baseline for shocks), 2003-40 ......................................... 8

I.2. Average EU Funds Spending …………………….........................................

I.3. Role of a Pro-Cyclical Policy on the Impact of EU Funds, Comparison with the Baseline Scenario of Counter-Cyclical Fiscal Policy ................................ $\underline{26}$

Table

I.1. Selected Calibration Parameters........................................................................

Appendixes

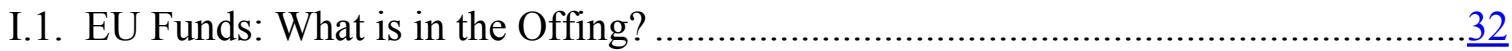

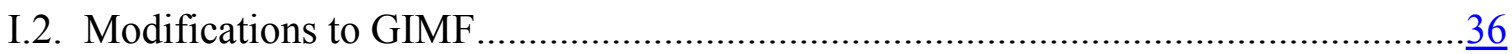

I.3. List of Parameters Used for the Calibration of the Model ……………………….......

Appendix Figures

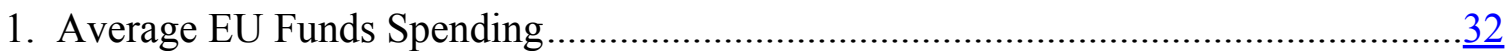

2. EU Funds Payments and Relative GDP per Capita …………………………….......33

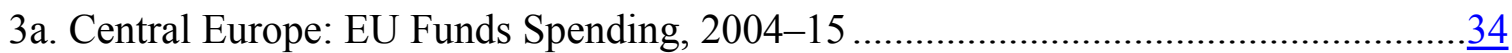

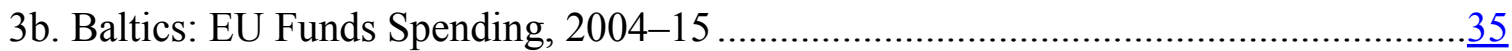

4a-d. EU Fund Transfer Shock, 2003-40 ................................................................. 
5a-d. Central Europe: EU Fund Transfer Shock, 2003-40 ………………………..... 45

6a-d. Baltics: EU Fund Transfer Shock, 2003-40 ........................................................49

II. What can Poland Learn From Other European Union Countries In Terms Of Labor

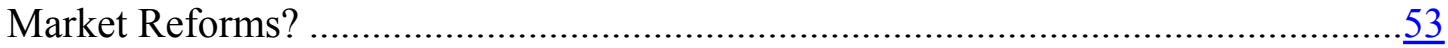
A. Introduction
B. Labor Market Institutions: A Short Overview .$\underline{55}$
C. The Dutch and Irish Experience
D. Empirical Analysis
E. Lessons for Poland $\underline{66}$
F. Conclusion
References.

Box

II.1. Centralized/Coordinated Wage Bargaining Agreements in Ireland.

Figures

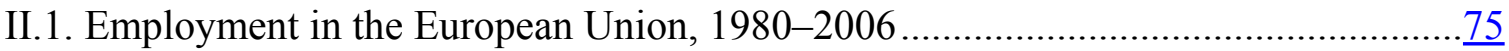

II.2. Wage Moderation in the European Union, 1980-2006 ………………………......

II.3. Fiscal Effects on the Labor Market, 1980-2006 …………………………….....77

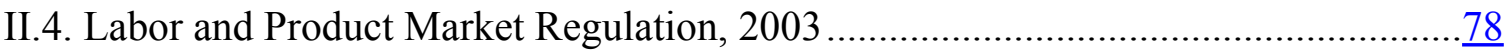

Tables

II.1. Estimating the Policy Determinants of Wage Moderation .........................................

II.2. Estimating the Effect of Wage Curve Shifts on Employment …………………...... 80

II.3. Fraser Institute Indicators of Administrative Burden in New Member States, 2004 


\section{Macroeconomic EfFects of EU TRAnSfers in NeW Member States ${ }^{1}$}

\section{A. Introduction}

\section{Large inflows from the European Union over the next few years could} significantly impact macroeconomic outcomes. The European Union's cohesion policy provides the basis for substantial transfers to member countries and regions that lag behind in terms of income or face particularly high unemployment. For the eight member states (NMS) that joined the union in $2004,{ }^{2}$ and for the additional two that joined in $2007,{ }^{3}$ this implies transfers that could exceed 3-4 percent of GDP per year during 2007-12 (Rosenberg and Sierhej (2007) and Appendix I). The growth dividend of such inflows continues to be debated, with opinions divided on whether they speed up convergence, on the channels through which these funds affect the economy and on their impact on resource allocation. A clear understanding of the macroeconomic impact of EU funds is however key to assessing current and future economic outcomes, hence informing policy alternatives.

\section{The discussion of the impact of EU funds resounds with issues still debated in} the aid and transfers literatures. These funds are essentially a cross-country transfer of resources, just like the Franco-Prussian War indemnity payments of the $19^{\text {th }}$ century, the German reparation payments following World War I, or the official development assistance flowing annually into low-income countries. The growth dividend of aid continues to be disputed, but there seems to be a growing consensus in favor of the argument that aid boosts growth by increasing total savings (Bulir and Lane, 2004; Easterly, 2003; Tressel, 2007). In this respect, the real exchange rate behavior is critical, reflecting opposing forces exerted by a transfer's income effects in the donor and recipient countries (Brock, 1996; Devereux and Smith, 2005). The impact of EU funds on incomes and savings should similarly be key in assessing their overall macroeconomic effect on NMS.

\section{In addition, a full account of the macroeconomic effects of $E \mathbf{U}$ funds requires} accounting for the NMS convergence process. The large income gap between these countries and the EU average is essentially a reflection of the NMS's lower productivity and capital stock. Gains in both fronts currently underpin the rapid catch-up process; and, EU funds should further support convergence to the extent that they encourage investment, for example. But EU funds could also slow convergence if the associated wealth effect increases demand for leisure and decreases labor supply. In this paper, we modify the IMF's Global Integrated Monetary and Fiscal (GIMF) model to reflect the convergence process underpinning the NMS's economies, and use it to analyze the impact of EU inflows on the

\footnotetext{
${ }^{1}$ Prepared by Céline Allard on the basis of a forthcoming working paper by C. Allard, N. Choueiri, S. Schadler and R. van Elkan.

${ }^{2}$ These are the Czech Republic, Estonia, Hungary, Latvia, Lithuania, Poland, Slovakia and Slovenia.

${ }^{3}$ Bulgaria and Romania.
} 
latter. We show the conditions under which the inflows would help speed up convergence, and the consequences on resource reallocation, intertemporal saving and investment decisions, and the real exchange rate. Our results also help assess the impact of EU funds inflows on inflation and government budget outcomes, impacts that should be brought to bear in identifying policy choices.

4. The rest of this paper is organized as follows. Section B offers a focused review of the vast aid and transfer literature that the paper builds on. Section $\mathrm{C}$ describes the main features of the GIMF model and how it was modified to account for income convergence. Section D spells out the impact of EU funds as exhibited in the model and highlights potential risks related to the authorities' policy choices, in particular in the fiscal area. Section E concludes.

\section{B. Review of the Literature}

\section{The EU's cohesion policy is predicated on the theoretical argument that low-} income countries need support to bridge their gap with the rich members of the union. Available growth models have different implications for the possibility of income catch-up (De la Fuente, 2002; Martin and Sunley, 1998; Rassekh, 1998; Temple, 1999). The standard Solow-Swan neoclassical model implies convergence of per capita output, while endogenous growth theories, by incorporating increasing returns and technological change, suggest that convergence in (per capital) levels does not take place but convergence in growth rates could. However, in either model, adverse sociopolitical conditions can delay or disrupt convergence; these conditions would thus require policy intervention, therefore validating EU's cohesion policy to bring initial conditions to more comparable levels between regions, as noted by Boldrin and Canova (2001). ${ }^{4}$

\section{Evidence on whether $\mathbf{E} U$ funds have been successful in the past in helping bridge} the income gap is mixed. ${ }^{5}$ The macroeconomic literature on the impact of EU funds can be divided into two broad groups: model simulations and econometric studies (Everdeen et al, 2003; Bradley, 2005). Simulations could be interpreted as the ex-ante impact of EU fundsthat is the effect they would be expected to have if they finance projects that are devised and implemented optimally and efficiently. Econometric studies, on the other hand, come closer to an assessment of the ex-post impact of EU funds:

\footnotetext{
${ }^{4}$ Moreover, in the presence of high fixed costs or of externalities generating increasing returns, market competition can result in income divergence as trade openness and infrastructure improvements push resources into areas where costs are low or externalities prevail.

${ }^{5}$ The related questions of how effective are aid and public investment/capital in promoting growth has been addressed at length, by a literature too broad to be reviewed here. On balance, however, the conclusion would seem to suggest a positive impact (see for example Bradley et al (Chp 9 in 1) or Genbger (journal of policy reform, 2005) for more details).
} 
- Econometric studies offer meager support for the growth impact of EU funds. These studies generally base their conclusions on cross-country growth regressions. While some find evidence of a positive growth impact of EU funds (Fayolle and Lecuyer, 2000; Garcia-Solanes and Maria-Dolores, 2001), others present inconclusive results (Gaspar and Leite, 1994 and Cappelen and others, 2001), or only for open economies. Boldrin and Canova (2001) find no evidence of income catch-up in the EU after the mid-70s, even in the case of EU funds disbursements. Nor do they find evidence that supports the growth divergence theory, the platform on which the EU's cohesion policy rests, in line with Tondl (1998), Fagerberg and Verspagen (1996), and Corrado et al (2005).

- Conversely, model-based simulations tend to support the growth impact:

$>$ The first models to be used were macro-econometric models with conventional Keynesian demand-side features and backward-looking expectations, like the European Commission's HERMES model and its successor, the HERMIN model (Bradley 2002, Bradley et al Chp 10 in 1; Bradley, 2002,). For Greece, Portugal, Ireland and Spain, which received some $1 \frac{1}{2}$ to 3 percent of GDP per year during the second half of the 90s, HERMIN simulations find that real GDP growth was boosted by between 1 and $4 \frac{1}{2}$ percent, but that income convergence would only increase by $1 / 2$ to 2 percent by $2010 .^{6}$

$>$ The European Commission has also drawn on dynamic general equilibrium (DGE) models with micro-foundations and forward-looking optimizing agents, like QUEST II, to evaluate the impact of EU funds. ${ }^{7}$ For EU fund programs over 1989-96, Roger (1996) finds that demand effects dominate in the short run, as the investments financed by EU funds take time to generate a growth impact, and points to a risk of real exchange rate appreciation and rising interest rates overshadowing the positive growth impact in the medium term. Nevertheless, the model predicts a permanent and positive supply-side impact on GDP in the long run.

> Outside the European Commission, Pereira and Gaspar (1999) find, in a 2sector endogenous growth model calibrated to Portugal, that annual EU fund inflows of $3 \frac{1}{2}$ percent of GDP during 1989-93 increased growth by about $1 / 2$ percentage point a year (both in the short and long run), with a maximum impact when EU funds were spent on infrastructure rather than on human capital accumulation. Similarly, Gaspar and Pereira (1995), and Pereira (1997) find a positive growth impact of EU funds disbursed to Greece, Ireland and Portugal. In their survey paper, Goybet and conclude that overall the EU funds impact on

\footnotetext{
${ }^{6}$ In contrast, Barry et al (2001) argue that EU funds explained at most 1/2 percentage point per year of Ireland's 8 percent annual growth during the 90 s.

${ }^{7}$ See Roger and in't Veld (2002) for a full description of the QUEST model.
} 
annual growth reaches only 0.4 percentage point, a result comparable to what Lolos et al (1995) and Lolos and Theodoulides (2001) find for Greece over 198999 using a computable general equilibrium model.

\section{The divergence between these two strains of evaluation can partially be} explained by differences in methodology. Everdeen et al (2003) have noted that it is not surprising to find less favorable assessments from econometric (ex post) studies, as several factors can hinder the optimal use of EU funds (as assessed in ex ante model simulations) such as crowding out, rent seeking, and capacity constraints. The findings of econometric studies may also be constrained by limitations in their approaches, from data availability and reliability to vulnerability to the Lucas critique or the ad-hoc specification linking EU funds to income growth rather than its level. On the other hand, model-based simulations require strong assumptions on structural parameters that may be hard to link to available data.

8. The literature on the impact of EU funds in NMS is less abundant. Lolos (2001), in discussing the possible impact of EU funds in NMS, interprets the past experience as suggesting a boost of $1 / 2$ percentage point to GDP growth for each 1 percent of GDP additional funds. In its most recent cohesion report, the Commission evaluates, based on simulations of ECOMOD, HERMIN and QUEST , that by 2020, GDP would be increased by 3 percent on average across the NMS thanks to EU fund inflows. Bradley and others (2006) and the Magyar Nemzeti Bank (2006) exhibit similar results respectively for Poland and Hungary, while Kaczor (2006) finds a much smaller effect on GDP but improvement in employment, labor productivity, and prices in the near term. Bradley and others (2006) also note that the external current account would deteriorate over the period of EU funds inflows but turn into a small surplus thereafter.

9. This paper is closest to the work undertaken by the Commission with its QUEST model, but it enriches the analysis with new features. The model used here is also an intertemporal DGE model. However, rather than studying each specific EU member country, the analysis focuses in this paper on a representative NMS receiving EU funds inflows consistent with the newly released 2007-13 Financial Perspectives. Moreover, unlike QUEST, the model used here specifically models the ongoing convergence process of the NMS and traces the impact of the funds through various aspects of the NMS's economies, not just GDP.

\section{Modeling the Effects of EU Transfers to Converging NMS Economies}

10. In this study, the macroeconomic effect of EU transfers is assessed using the Fund's open macro model calibrated separately for the Central European and Baltics economies. The Global Integrated Monetary and Fiscal model (GIMF) is a large scale version of new open-economy macroeconomic models, with microeconomic foundations based on optimizing forward-looking consumers and producers under sticky prices, real and nominal rigidities, monopolistic competition as well as explicit cross-country linkages 
(Kumhof and others, 2007a; Kumhof and others, 2007b). The GIMF has a number of advantages over traditional large scale models. ${ }^{8}$ For our purposes, key features are nonRicardian consumers - barriers to full intertemporal consumption smoothing are still pervasive in NMS - a richly defined production structure that includes public capital and allows intra-industry (in addition to final goods) trade across economies, the inclusion of a monetary sector with either a fixed exchange rate or an inflation targeting regime and of an explicit fiscal reaction function. We consider two types of recipient countries: moderatelysized, relatively open inflation targeters (CEEs, IT) and very small, very open fixedexchange rate economies (Baltics, FE).

\section{This study also tailors the GIMF model to capture the catch-up process} currently experienced by these countries as well as the transfers of financial resources

from the EU. We use a two-country version of the model, whereby the "home" country is an EU fund recipient and the "rest of the world" is represented by the EU15. Adjustments to standard model are the following:"

- Convergence baseline: In contrast with the standard GIMF setting where both countries are already at the same level of development, we design a baseline scenario where the EU fund recipient country converges towards the EU15 level. More specifically, our baseline scenario has the NMS's GDP per capita gradually rising from 60 percent of the EU15 level in 2003 to close to 75 percent twenty years later, through a catch-up in total factor productivity in the tradable sector (Figure 1). ${ }^{10}$ As a consequence, throughout the convergence path, both the labor productivity gap and the capital to labor ratio gradually close, capturing a trend of capital accumulation that would happen even in the absence of EU fund inflows. Part of the production shifts to the tradable sector as it becomes more productive. Still, the rise in demand also leads to a deterioration of the trade balance. Productivity gains in the tradable sector lead to wage increases that firms in the nontradable sector pass on to consumers, triggering an increase in nontradable prices related to tradable prices and generating a trend appreciation of the real exchange rate.

\footnotetext{
${ }^{8}$ In particular, unlike traditional macroeconometric models, it is not subject to the Lucas critique when structural changes modify underlying behaviors, as is likely the case in converging NMS.

${ }^{9}$ Appendix II explains in more details the modifications to the standard model.

${ }^{10}$ See Appendix I for more details on GDP per capita in the NMS.
} 
Figure 1. Convergence scenario (baseline for shocks), 2003-40
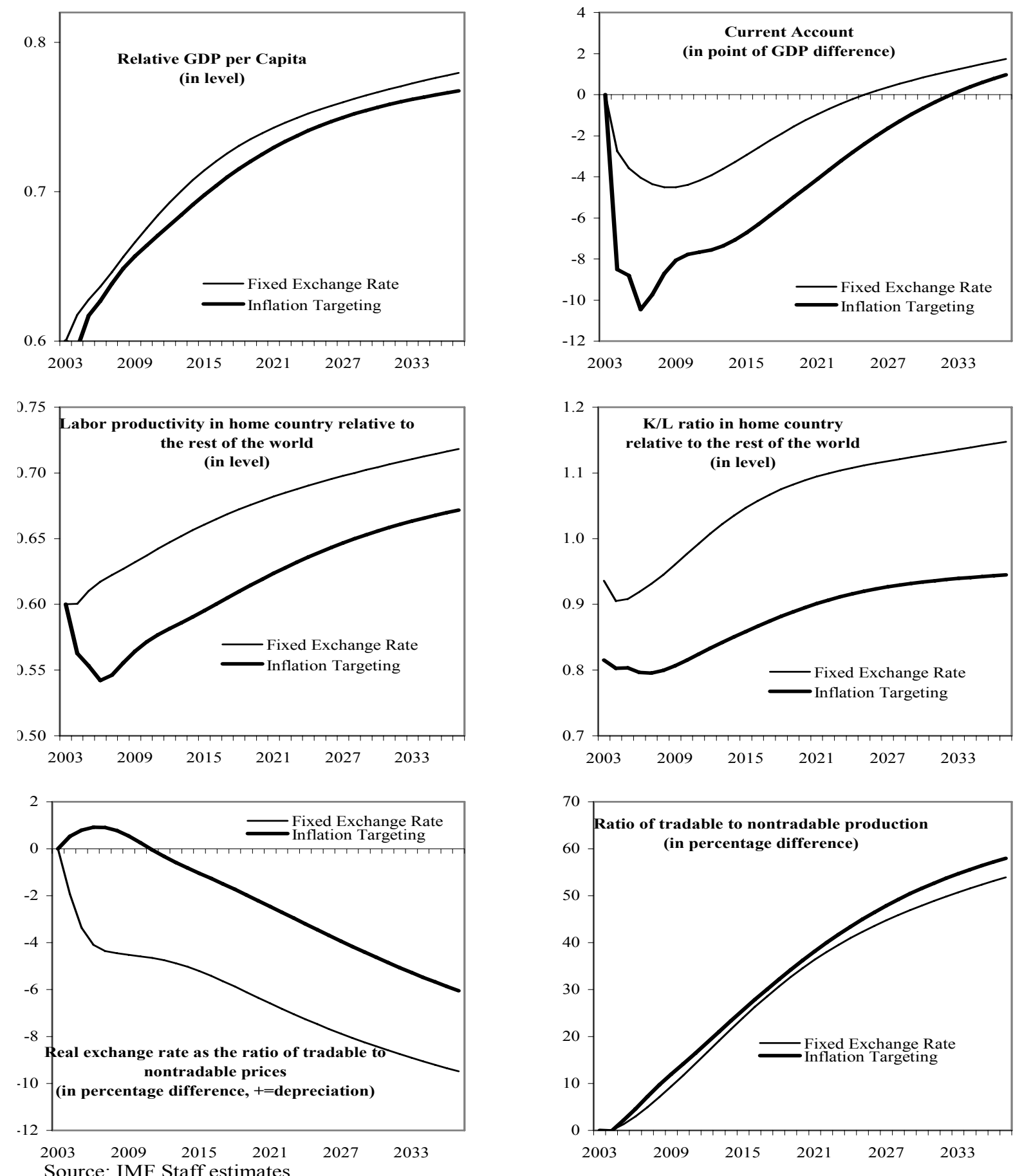

- Impact of EU funds throughout the economy: We introduce cross-country transfers from the EU15 to the NMS in the model in the form of a flow of (financial) resources transiting through the current account. These transfers have to be spent in the year they are received. Furthermore, we distinguish between transfers to the private sector, which go directly to support households' income, and transfers to the public sector, which finance public investment. In practice, some EU funds are also directed to private sector 
firms. These funds are not captured in this exercise but their impact is likely to be similar to those funding public investment in so far as they boost the capital stock.

- Impact of public investment on total factor productivity (TFP): Given the nature of the EU fund infrastructure projects - a public good that will boost private firms' profitability - we assume that they will have a positive impact on TFP, unlike in the standard model where TFP is exogenous and independent of the amount of capital stock. The elasticity of TFP to the public capital stock is calibrated based on the average estimate found in the literature (see Lightart and Suarez (2005)). ${ }^{11}$

12. Other features of GIMF are maintained. The main features of GIMF relevant for this study include the following elements:

- Households are forward-looking, and hence know that the EU transfers are only temporary. They own the firms and decide how to allocate their time between work and leisure. Except for a portion of households that do not have access to financial markets (liquidity-constrained households), all agents make their consumption decision intertemporally. Other non-Ricardian features of the model include consumer myopia, declining lifecycle income profile that make future labor income taxes less relevant to lifetime wealth, and distortionary taxes.

- Firms produce goods according to constant elasticity of substitution (CES) production functions using labor, capital, intermediate foreign and domestically-produced inputs. Goods and labor differentiation provides firms and unions (which buy labor from households and sell it to firms) with monopolistic market power. Because of nominal and real adjustment costs, macroeconomic variables respond only gradually to shocks.

- Fiscal policy is countercyclical. Taxed levied on consumption, labor and capital as well as lump sum taxes provide resources for public consumption and investment. Over the long run, taxes adjust to stabilize the deficit balance at the government's chosen target (assumed to be the average balance over the last ten years). In the short run, however, automatic stabilizers are allowed to work: temporary revenue windfalls from cyclical upturns are used to reduce debt, while the public balance is allowed to temporarily deteriorate under cyclical downturns.

\footnotetext{
${ }^{11}$ As the results are sensitive to this assumption, the discussion of the results in Section D is accompanied by a sensitivity analysis.
} 
- Monetary policy in Central European countries reflects their inflation-targeting regime - with a target of $2 \frac{1}{2}$ percent — while in the Baltics the nominal interest rate follows the world interest rate as nominal exchange rates are fixed. ${ }^{12}$

13. The calibration is based on historical averages for the past decade (Table 1 and Appendix III). Values of the exogenous and steady state endogenous variables for the representative Central European NMS are constructed by averaging the corresponding data for the Czech Republic, Hungary, Poland, Slovakia and Slovenia over 1995-2005. Values for the representative Baltic NMS are constructed by averaging data for Estonia, Latvia and Lithuania over the same period. As for structural parameters, they were largely taken from the literature on Western Europe (Bayoumi, Laxton and Pesenti (2004), Everaert and Schule (2006)) or Chile (Kumhof and Laxton, 2007c), when these parameters were not available for NMS. In addition, we assumed lower adjustments costs to nominal variables in the Baltics than in Central European countries, as agents are expected to be willing to change prices more often when the nominal exchange rate-fixed in the former, flexible in the latter-is not available as an adjustment variable. The expected flow of EU transfers over 2004-15-as described in Appendix I - is used to calibrate the transfers in the model.

Table 1. Selected Calibration Parameters

\begin{tabular}{|c|c|c|c|}
\hline & CEEs & Baltics & EU15 \\
\hline \multicolumn{4}{|l|}{ Ratios to GDP } \\
\hline Investment Share & 25.0 & 28.7 & 18.4 \\
\hline Net Financial Asset Position & -40.7 & -66.7 & - \\
\hline Government Expenditures & 21.6 & 19.2 & 22.0 \\
\hline Government Debt & 37 & 32 & 66 \\
\hline \multicolumn{4}{|l|}{ Households' parameters } \\
\hline Share of Liquidity Constrained Consumers & 0.45 & 0.45 & 0.25 \\
\hline Population Ratio & $1 / 29.5$ & $1 / 161.7$ & 1 \\
\hline \multicolumn{4}{|l|}{ Rigidities And Competition Parameters } \\
\hline Price Adjustment Costs in Productive Sector & 13 & 1.3 & 13 \\
\hline Price Adjustment Costs in Trade Sector & 10 & 1.0 & 10 \\
\hline Quantity Adjustment Costs in Retail and Trade Sectors & 7 & 0.7 & 7 \\
\hline Quantity Adjustment Costs for Investment & 9 & 4 & 9 \\
\hline \multicolumn{4}{|l|}{ Mark-up Between Varieties (in percent) } \\
\hline Productive Sector & 14 & 14 & 14 \\
\hline Retail Sector & 5 & 5 & 5 \\
\hline Trade Sector & 2.5 & 2.5 & 2.5 \\
\hline \multicolumn{4}{|l|}{ Production parameters } \\
\hline Elasticity of GDP to Public Capital Stock & 0.15 & 0.15 & 0.1 \\
\hline Elasticity of GDP to Public Consumption Stock & 0.01 & 0.01 & 0.01 \\
\hline
\end{tabular}

Source: Eurostat; authors' calculations.

\footnotetext{
${ }^{12}$ There is no risk premium, to maintain as much simplicity as possible in the model. Monetary policy in "the rest of the world" assumes a 2 percent inflation target.
} 


\section{The general equilibrium nature of GIMF precludes imbalances such as an}

output gap in the baseline scenario. The model is calibrated and solved for a steady state of smooth convergence vis-à-vis the EU15. ${ }^{13}$ Therefore, unlike macro econometric models, this set-up cannot reproduce exactly the past fluctuations of every variables of a specific country. In particular, it cannot capture the country's position in the cycle but rather assumes that the starting point - that is, steady state, or baseline - is one in which the economy's potential is consistently realized. ${ }^{14}$. For that reason, we chose to work with representative countries, instead of calibrating the model and running the shocks separately for every recipient country among the NMS. We therefore avoid giving the illusion of precision that the model does not have, and focus on identifying the core mechanisms at work.

\section{Simulation Results and Lessons for Policymakers}

\section{To better understand the transmission mechanisms at work, we first consider} the macroeconomic effects of allocating the entire amount of EU transfers either to boost households' income or to augment public investment. The size and time profile of the EU inflows is calibrated using Rosenberg and Sierhej's paper (2007). In the first case we examine, all transfers are grants to households; in the second case, transfers go through the government's budget, which spends it entirely on public investment. In order to simplify the discussion, in each of these cases, all households are assumed to smooth their consumption pattern without any liquidity constraint. We later reintroduce liquidity constrains, however, when we evaluate the impact of the EU funds using the actual expected breakdown between income

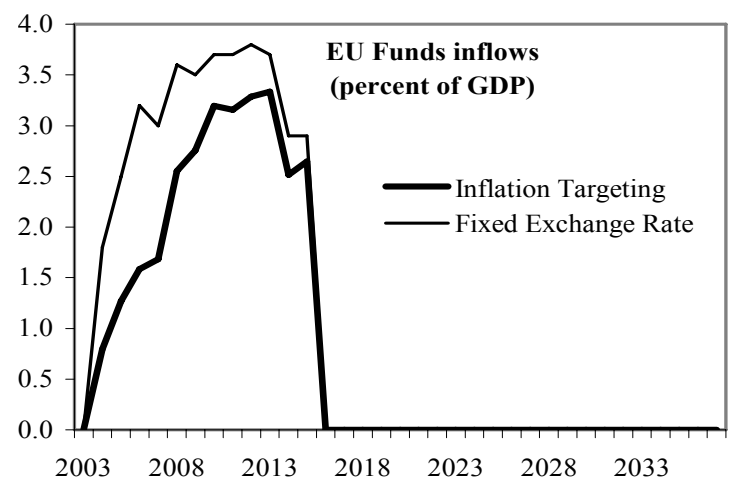
support and public investment.

\section{Case 1: All EU transfers as households' income support:}

\section{Transfers are partly consumed immediately and partly saved, with only a} marginal impact on real interest rates. Households use the transfers - which they know to be temporary - to smooth their consumption: they consume part of the transfers immediately, both in domestic and imported goods, lower their immediate labor supply and save the rest of

\footnotetext{
${ }^{13}$ As mentioned above, this steady state constitutes our baseline to which a "shock" is then applied in the form of EU funds transfers from the "rest of the world" to the representative NMS, the "home country", over a specific period of time.

${ }^{14}$ As a consequence, caution should be applied when interpreting the results of shocks for each of the actual NMS. For example, if EU funds are disbursed to one of the NMS when it is at the peak of its economic cycle, the impact of a short-run boost in demand is likely to be magnified relative to that suggested by the model.
} 
the transfers. In this regard, the impact on the real interest rate is the result of opposing forces:

- As the transfers are not entirely consumed immediately, the extra savings are invested abroad, and the net foreign asset position consequently increases. The savings also improve the current account when including the EU transfers.

- At the same time, the extra immediate consumption puts pressures on domestic resources and hence on domestic real interest rates. Meanwhile, firms see their profitability reduced because of lower labor supply, which depresses their investment plans and consequently puts downward pressures on real interest rates: the additional consumption is initially achieved through lower resources devoted to investment.

- The two forces on real interest rates more or less offset each other, and the real interest rate is virtually unaffected, with a very marginal increase in the short/medium term (period of EU inflows) and no change beyond that period.
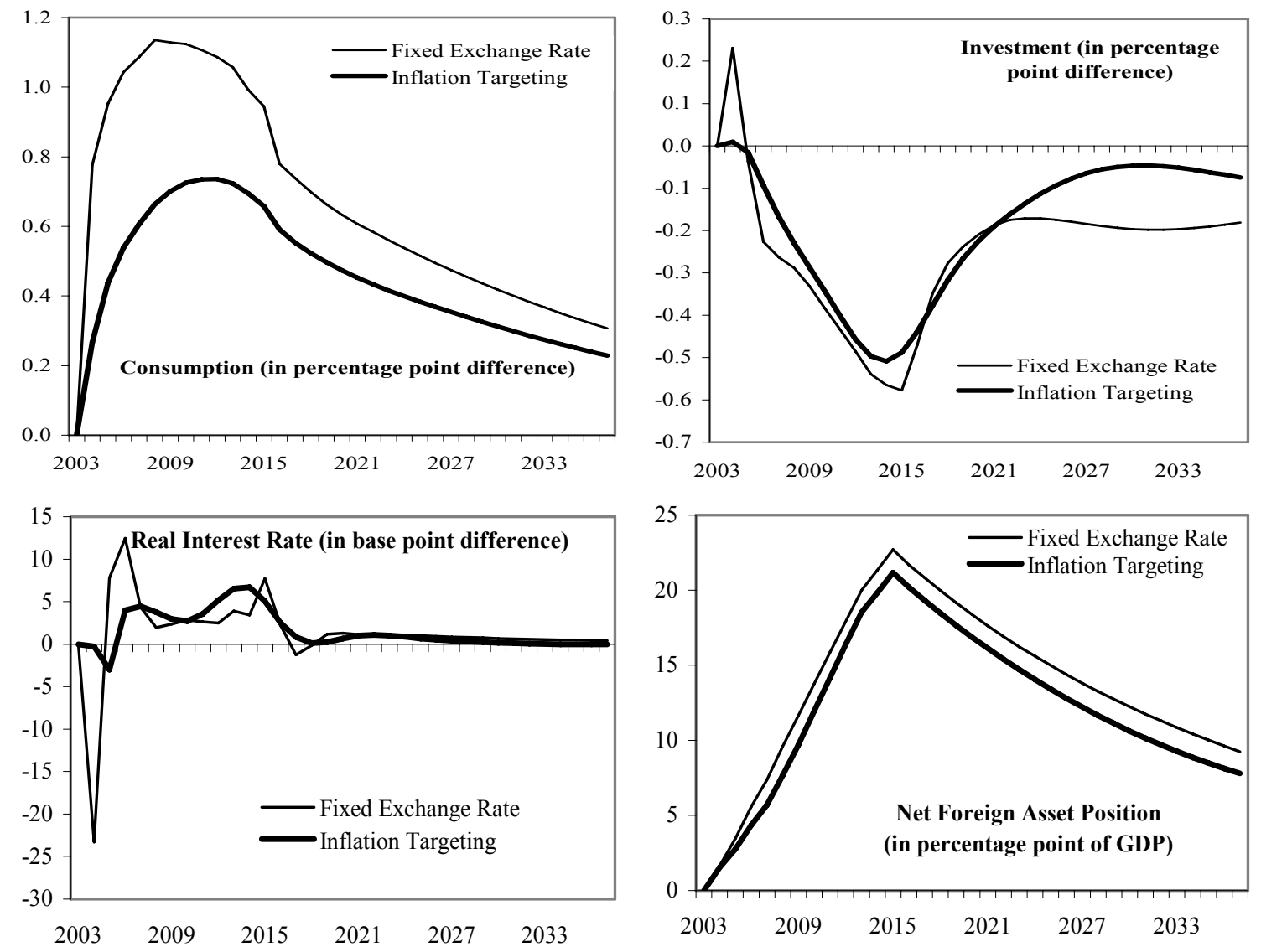

17. The trade balance and competitiveness deteriorate. With lower labor supply and marginally higher interest rate, domestic production is not able to fulfill the surge in 
consumption, and the additional demand is satisfied through net imports. The current account excluding transfers deteriorates over the period of EU inflows. Lower labor supply pushes wage up. The resulting increase in production costs leads to domestic price pressures, triggering an appreciation of the real exchange rate expressed in terms of foreign versus domestic prices (external exchange rate).
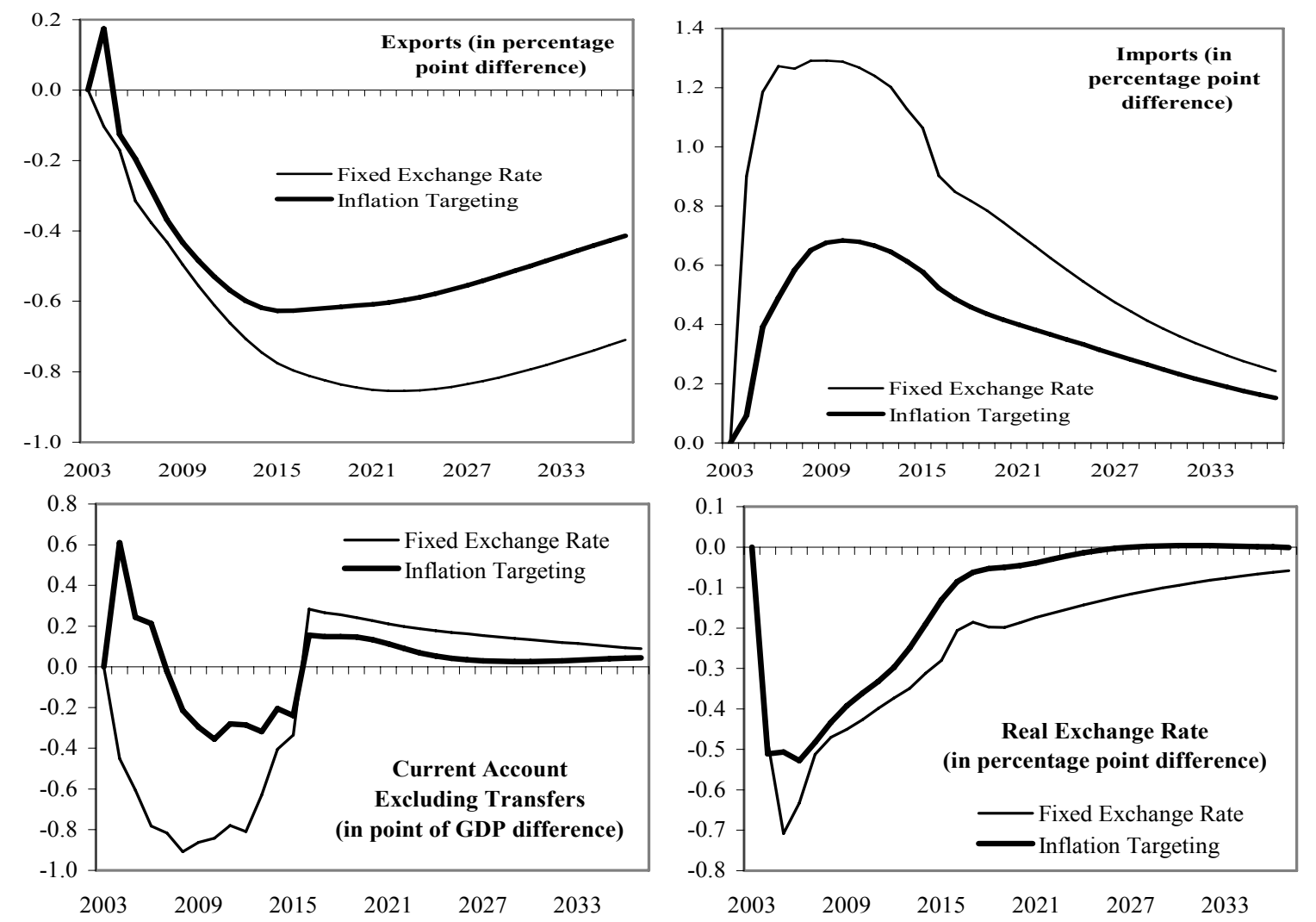

18. Domestic production shifts towards nontradable goods, which is a standard

Dutch disease effect. Households' increase demand for the composite good generates more demand for both tradable and non tradable intermediary goods. ${ }^{15}$ As only tradable goods can be imported, domestic production shifts from tradable to nontradable goods; this shift is made possible through an increase in the relative price of nontradable goods; in other words, the exchange rate in terms of tradable to nontradable prices (internal exchange rate) appreciates too.

\footnotetext{
${ }^{15}$ In GIMF, there is no tradable and nontradable consumption goods. Instead, retailers package tradable and nontradable wholesale goods into a composite good, which is then put on the market. Households' demand is expressed in terms of that composite good.
} 

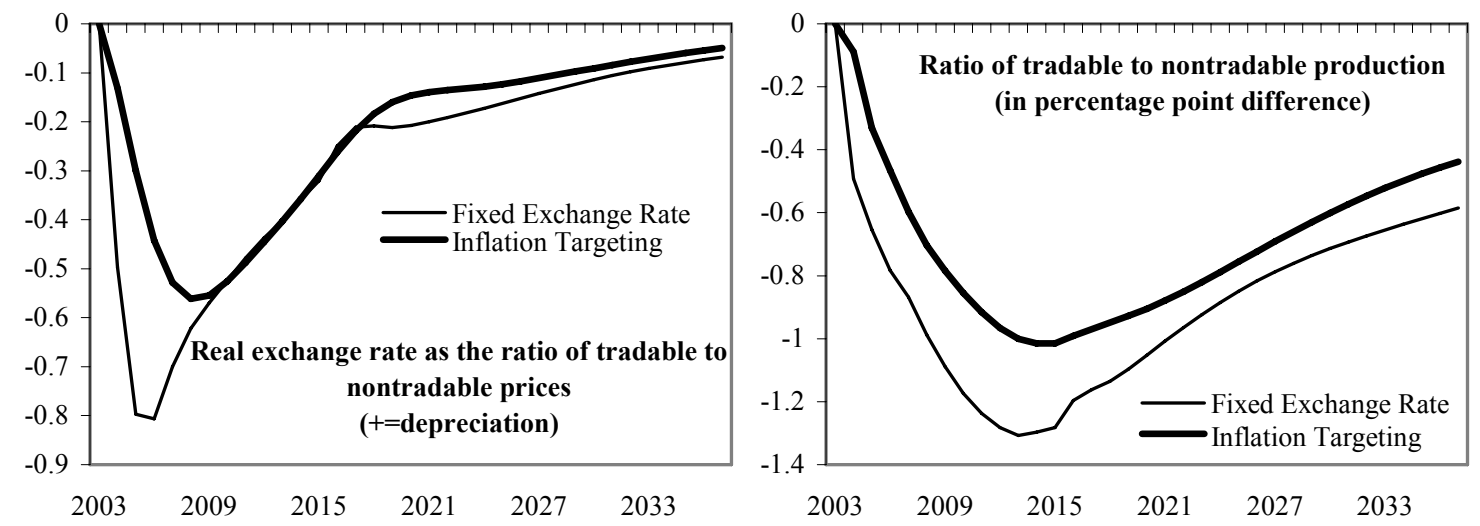

19. The boost to GDP from the EU transfers is short-lived, and convergence only marginally affected. Once the effects on prices and labor supply behaviors fade away, firms' incentives essentially return to the pre-EU fund situation as productivity is unchanged. As a consequence, the initial demand-driven increase in GDP fully disappears as soon as the EU funds stop flowing in, and GDP per capita is virtually unchanged.
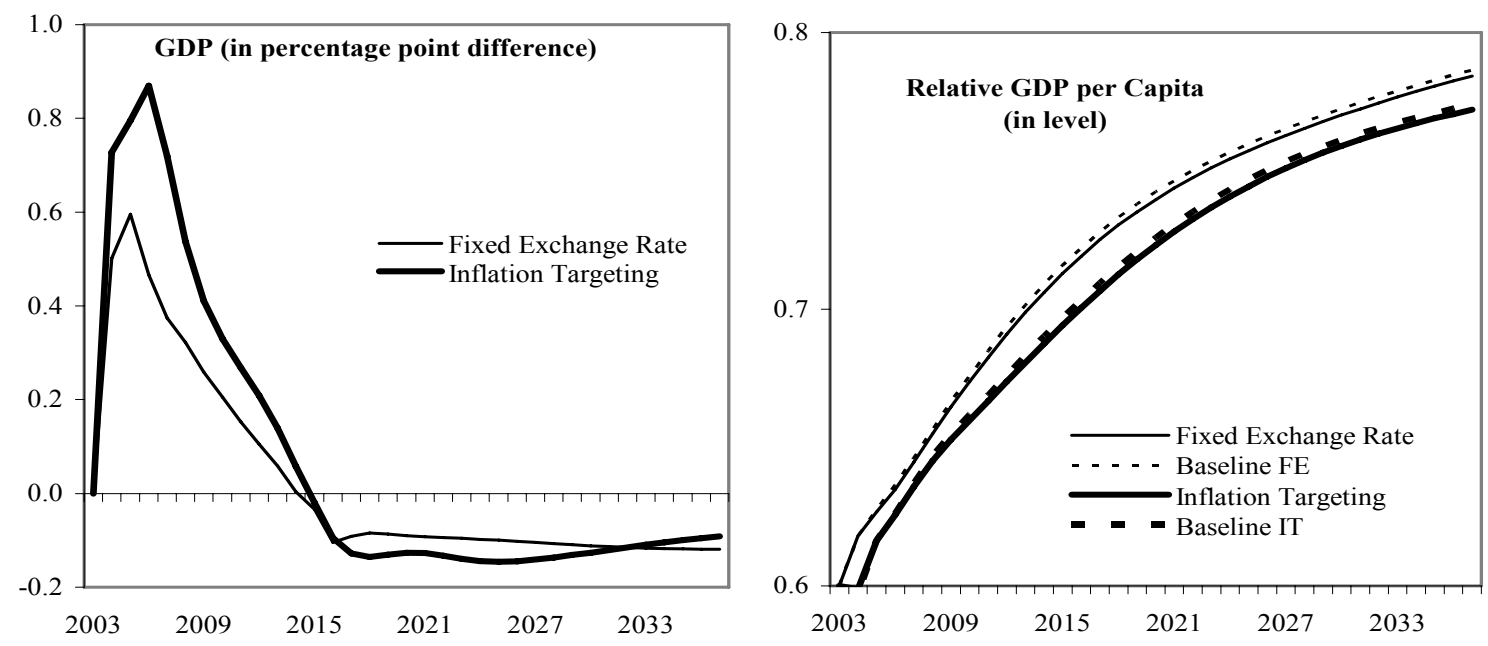

\section{Case 2: EU transfers financing public investment}

20. The boost to public investment puts upward pressure on the real interest rate over the period of EU inflows, but relieves pressures in the long run, as productivity gains materialize. The transfers, as they finance public investment, affect the investmentsaving balance and the immediate resources available for demand, through two channels:

- High public capital raises private investment's productivity and firms are willing to increase their investment program immediately, putting upward pressure on the real interest rate.

- Similarly, households integrate in their consumption pattern the expectations that growth — and hence their income — will be hiked in the future by productivity gains. 
As a consequence, they bring forward part of this future wealth and increase their consumption immediately, leading to a decline in their savings effort in the initial period. As opposed to the case where EU funds finance households' income support, labor supply moderately improves as no direct transfer comes to reduce households' incentives to work.

- As a consequence, the real interest rate rises significantly during the period of EU flows. Initially, the surge in demand has to be fulfilled with inelastic supply, something achieved through higher real interest rates and an initial dampening of firms' investment plans: private investment is crowded out until enough output can be produced to cover both increased consumption and investment. Once the EU transfers stop flowing, pressures from private consumption diminish, as liquidity-constrained households have exhausted their income support. In the meantime, productivity gains generated by public and private investment boost supply over time, allowing the real interest rate to stabilize at a lower level in the long run.
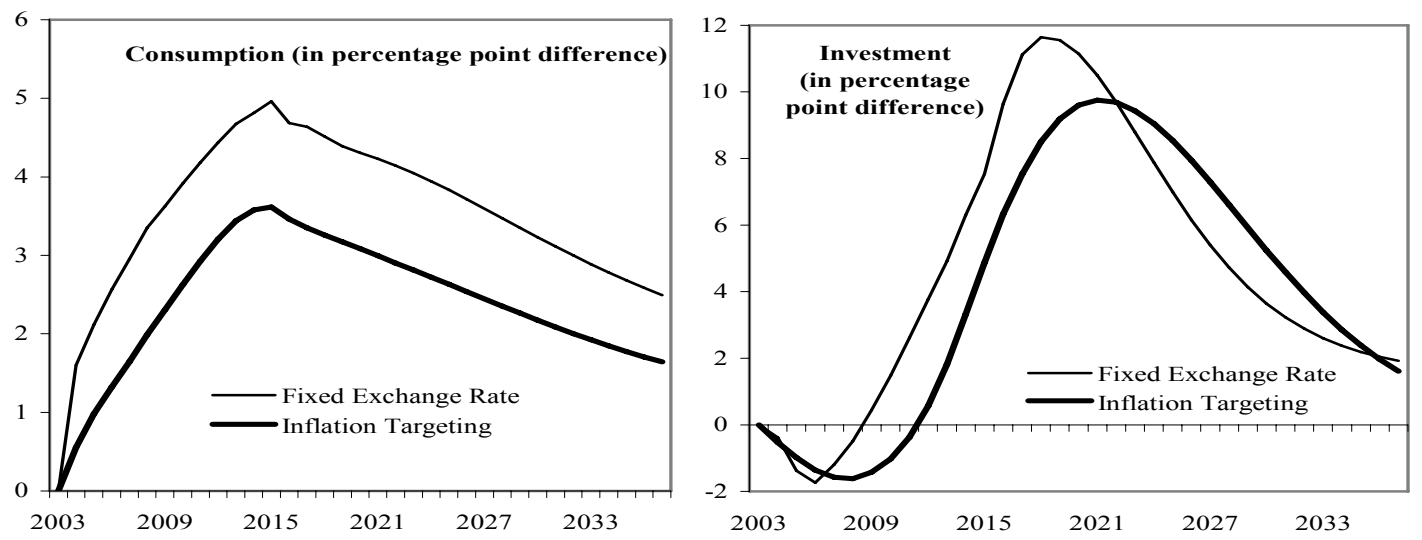

21. The current account, even including transfers, deteriorates initially but competitiveness improves substantially in the medium and long run. With households saving less and the full amount of EU inflows used immediately to boost public investment - compared to the case 1 where EU funds inflows to households were partially saved - the pressures on domestic resources materialize more decisively and net imports surge. The net foreign asset position initially deteriorates (or does not improve), before recovering over the medium-run, as the investment effort eventually leads to increased competitiveness. After an initial appreciation due to demand pressures, the external real exchange rate gradually depreciates, as domestic production capacity builds up: being more productive, firms can sell at better prices than their foreign competitors. As a consequence, once transfers taper off, the recipient country experiences a sharp improvement in its trade balance. 

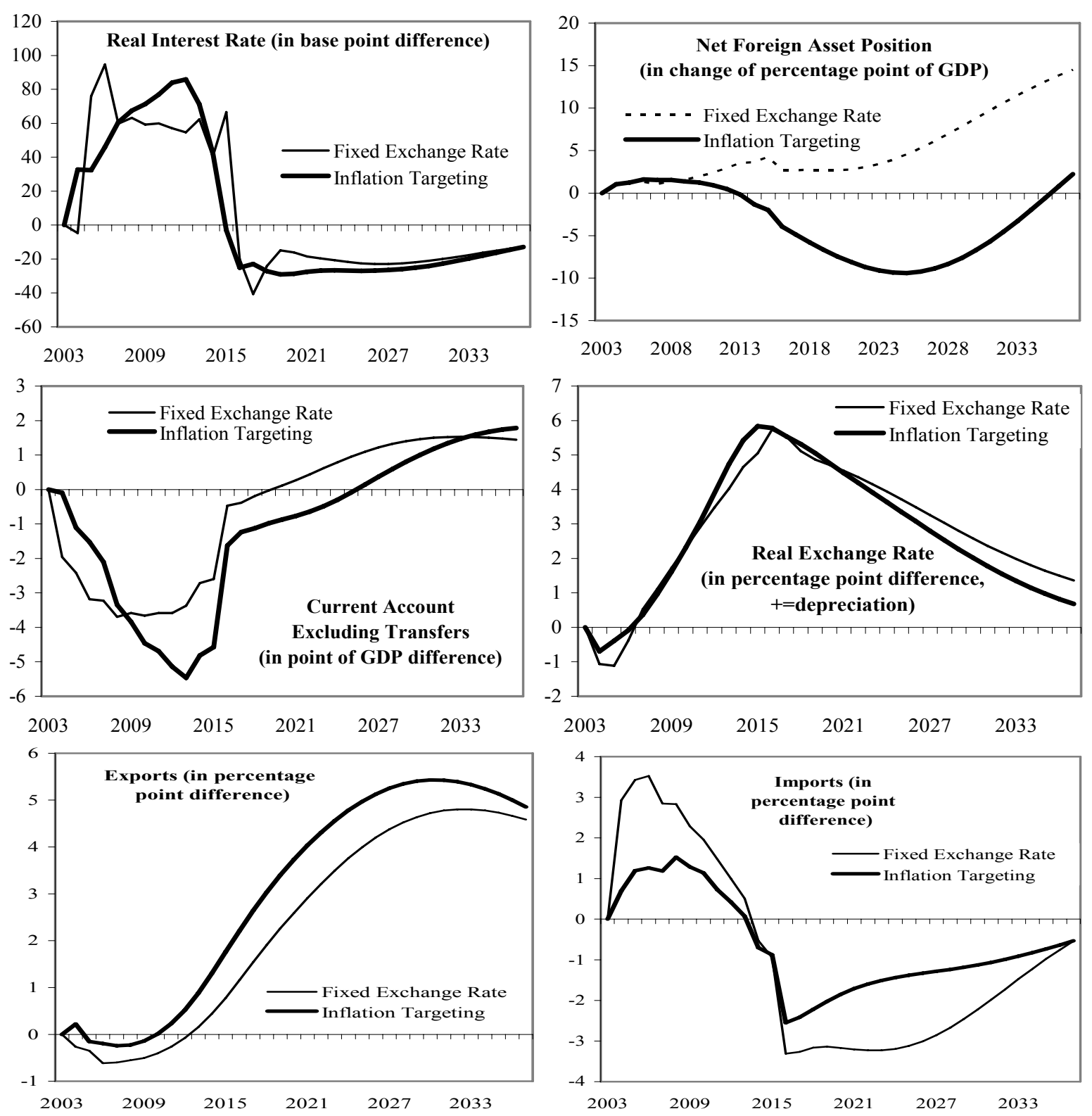

- $\quad$ The initial shift to non-tradable production is only temporary. The initial crunch on domestic resources leads to a shift of production to nontradable goods, as tradable goods are imported. However, production is quickly reallocated to the tradable sector once the EU fund inflows end, as the domestic exporting capacity gets boosted by the productive gains. The internal real exchange rate follows this pattern of production: it initially appreciates before depreciating once the flows of EU funds wanes. 

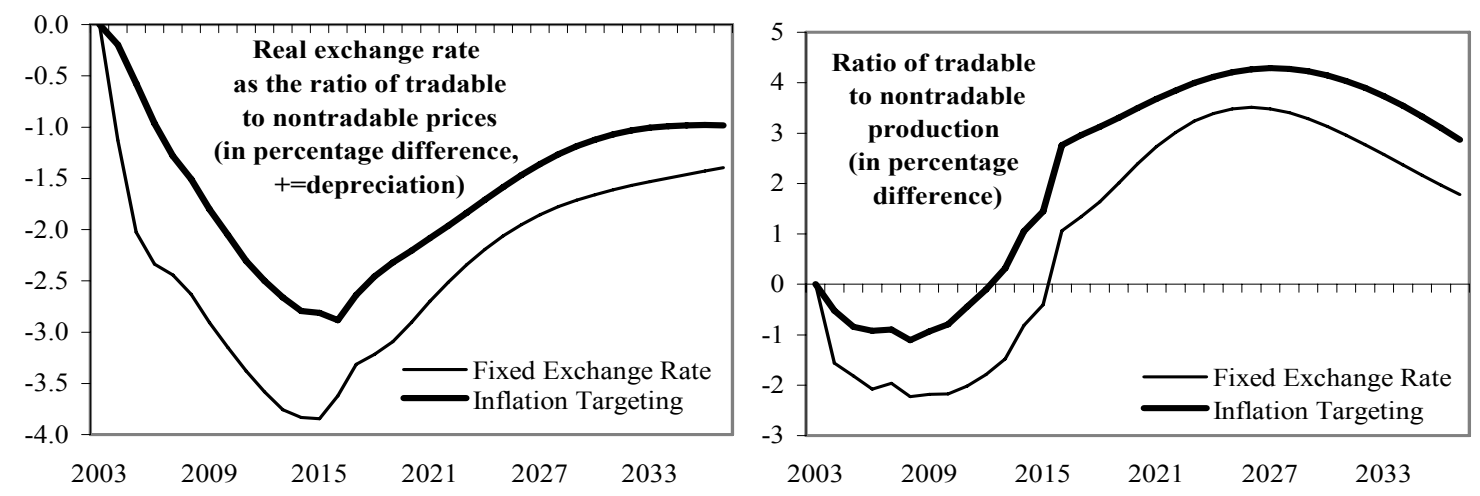

- $\quad$ As the EU funds are spent to spur the recipient's productivity, the real effects on GDP outlive the inflows and thus provide a lasting income convergence effect. Relative GDP per capita compared to EU15 would be boosted by close to 10 percentage points compared to a no-EU funds scenario.
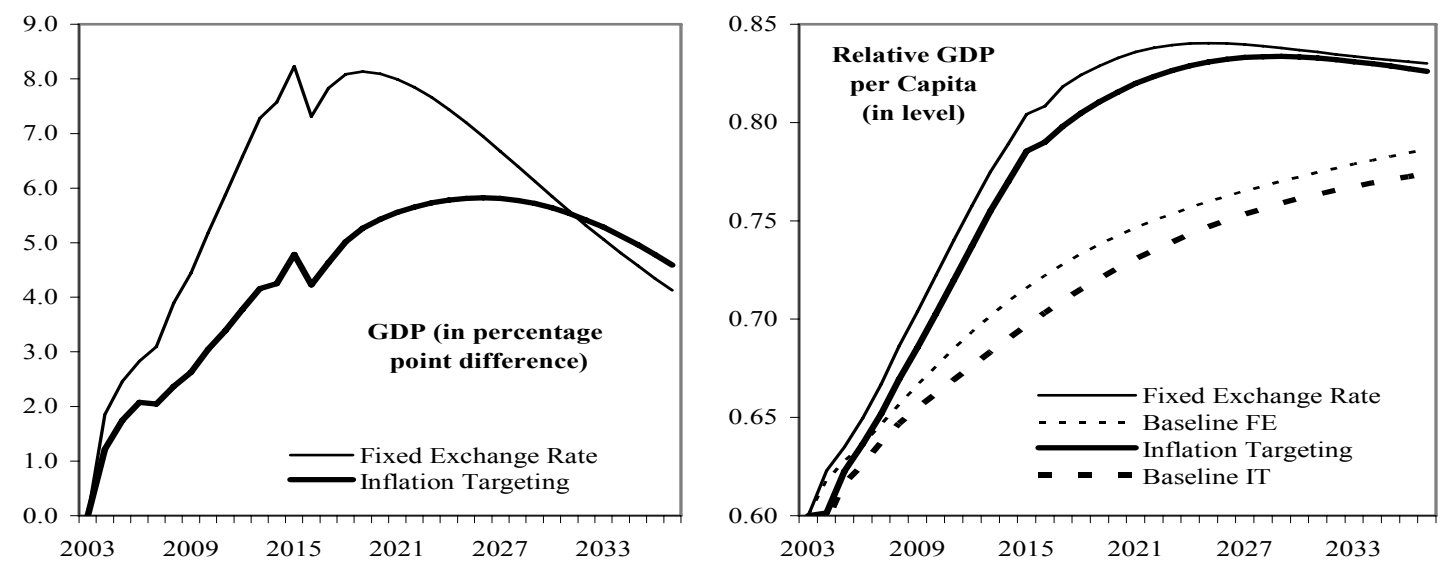

\section{Putting it together: three lessons for policymakers}

\section{First, gains from EU transfers - potentially substantial—will depend critically} on the share on productive investment. ${ }^{16}$ We evaluate the impact of EU funds using the estimated breakdown between income support and public investment provided by Rosenberg and Sierhej (2007) (Figure 2). In this scenario, activity would be gradually but substantially boosted, with significant gains in terms of consumption and ultimately welfare. ${ }^{17}$ The impact on consumption would be more front-loaded, as liquidity-constrained households spend their gains immediately. However, it also appears clearly that most of the impact would derive

\footnotetext{
${ }^{16}$ Appendix Figures 3, 4 and 5 show in details the results for both the inflation targeting and fixed exchange rate regimes, broken down between the impact of private and public EU funds.

${ }^{17}$ In these simulations, welfare and consumption are tied closely together because, as the economies are initially at equilibrium in the model, the EU transfers generate little change in the level of labor and hence of leisure (Appendix Figure 4c). Results on welfare would be less clear-cut for countries that started receiving EU funds at a period when unemployment was above their natural rate.
} 
from the funds spent on public investment: As exemplified by the stylized cases, EU funds

Figure 2. Average EU Funds Spending (percent of GDP) 1/
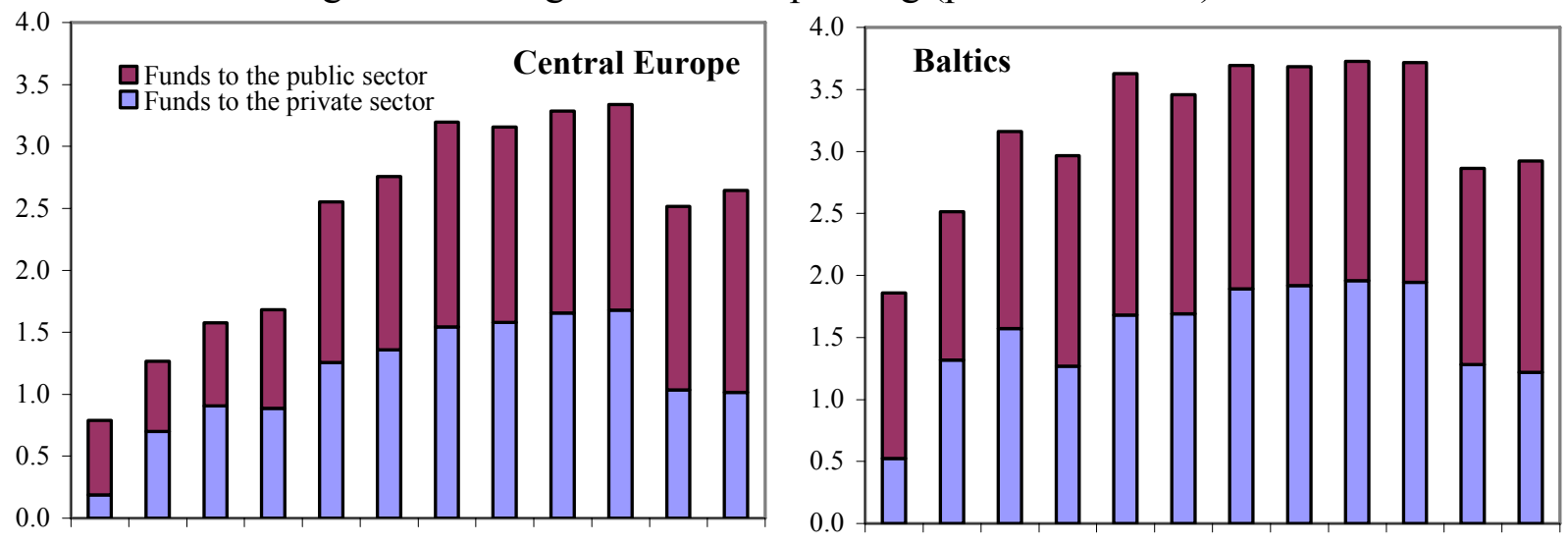

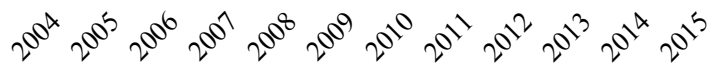

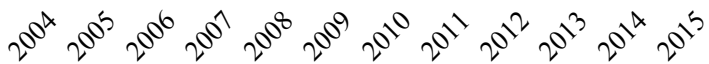

Source: Rosenberg and Sierhej (2007); IMF WEO. 1/ The aggregation is derived from a simple average.

channeled directly to households (a temporary demand shock) would have a very limited and short-lived effect, while the financing of public investment (a relatively long-lived supply shock) would generate most of the impact, as it fosters productivity and capital accumulation over time. ${ }^{18}$ In that respect, it is important to underscore that the difference in magnitude for GDP developments between the Baltics and Central European countries stems essentially from the EU inflow assumption: EU funds financing public investment are predicted to be larger and more front-loaded in the Baltics.
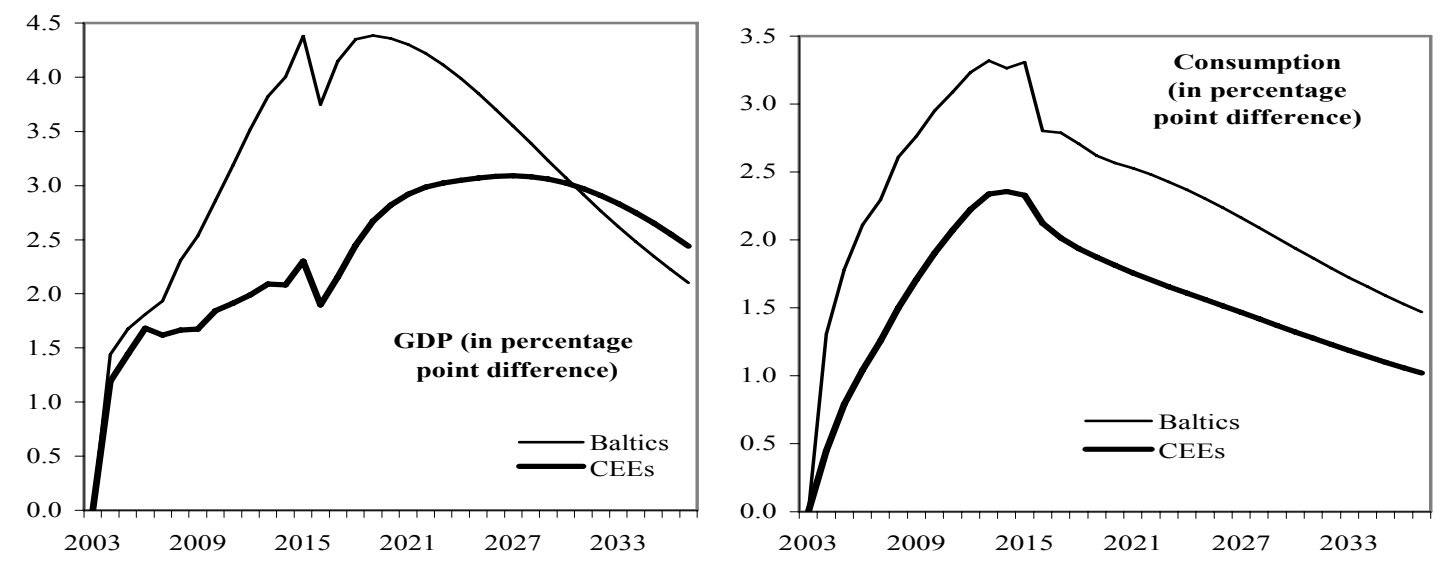

\footnotetext{
${ }^{18}$ EU-funded public investment is supposed to stop in 2015. At this date, the impact of public capital stock, and hence on the economy's overall productivity, is maximal. But with a depreciation rate of public capital of 4 percent, the impact on the stock of capital remains apparent until almost 2040 (see Appendix I for more details).
} 

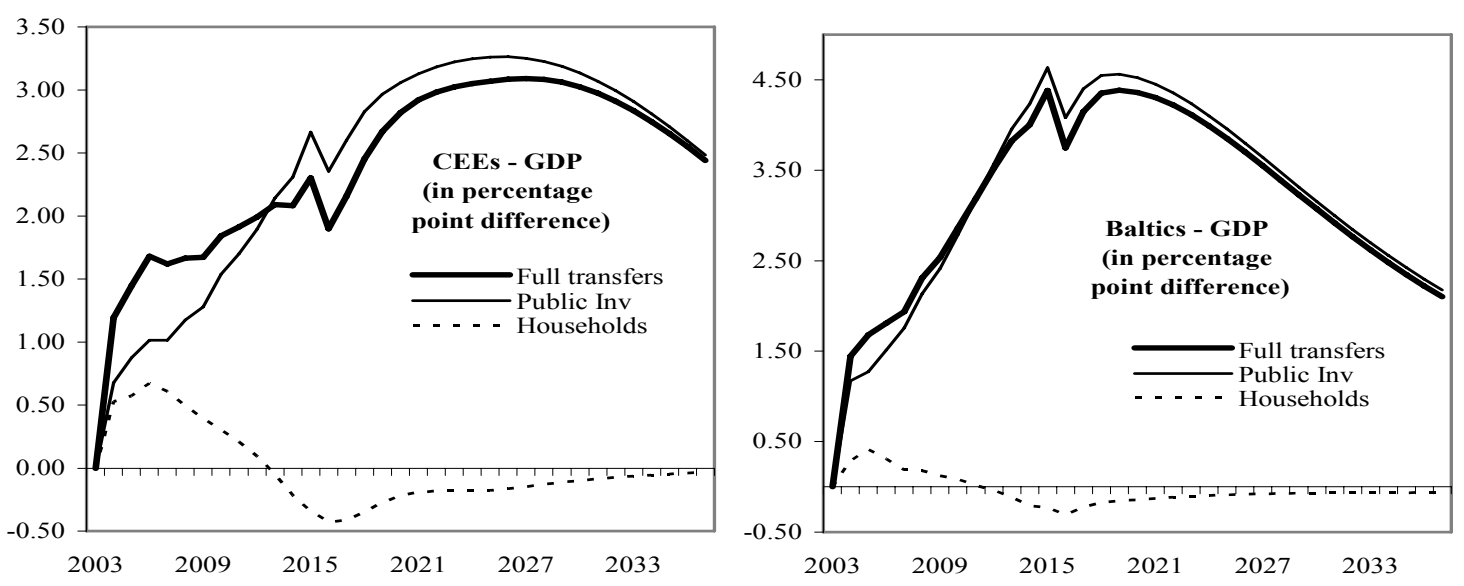

23. The trade balance would deteriorate, but EU transfers would more than offset it, leading to an improvement in the current account balance during the period of $\mathbf{E U}$ inflows. Imports would immediately increase under consumption and investment demand pressures, and also because, as foreign and domestic goods are used complementarily, increased domestic production would call for higher imports of intermediary goods. Meanwhile, exports would only gradually adjust upward, as it would take time for the increased installed capacity to translate into higher competitiveness. The bulk of the trade balance deterioration would, here again, derive from EU-financed public investment, as capital goods would be imported, but also because households would bring forward some of their consumption, in expectation of future growth. However, EU funds would still more than cover the deterioration in trade balance, so that the headline current account balance would moderately improve.
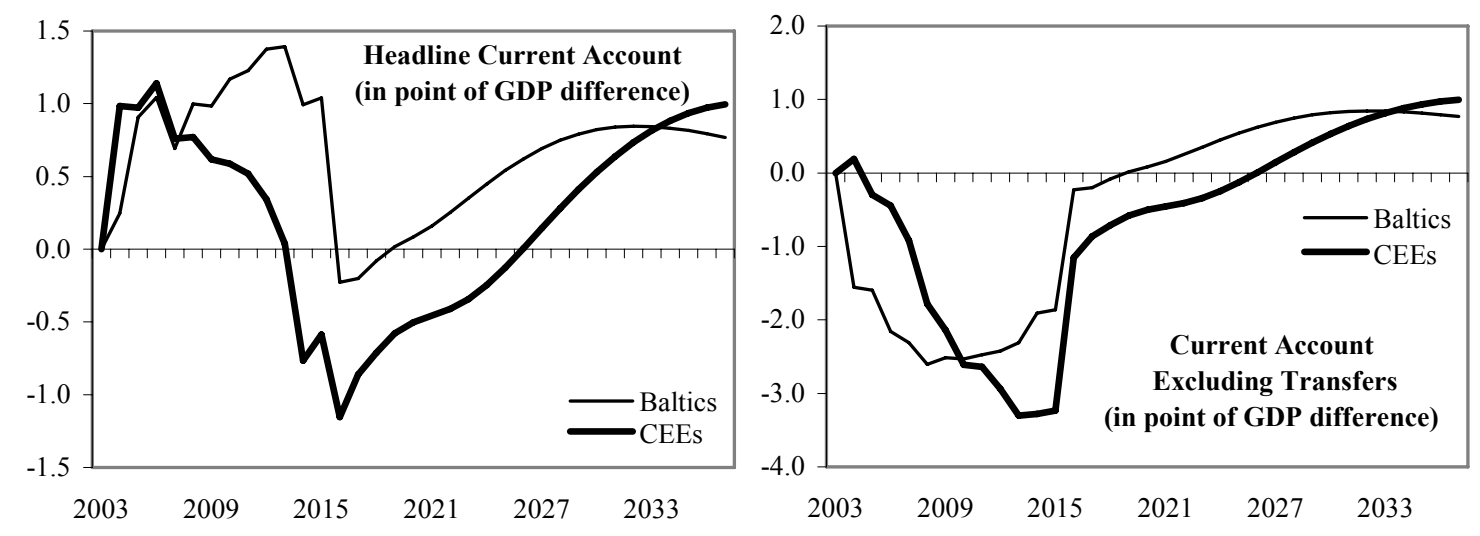

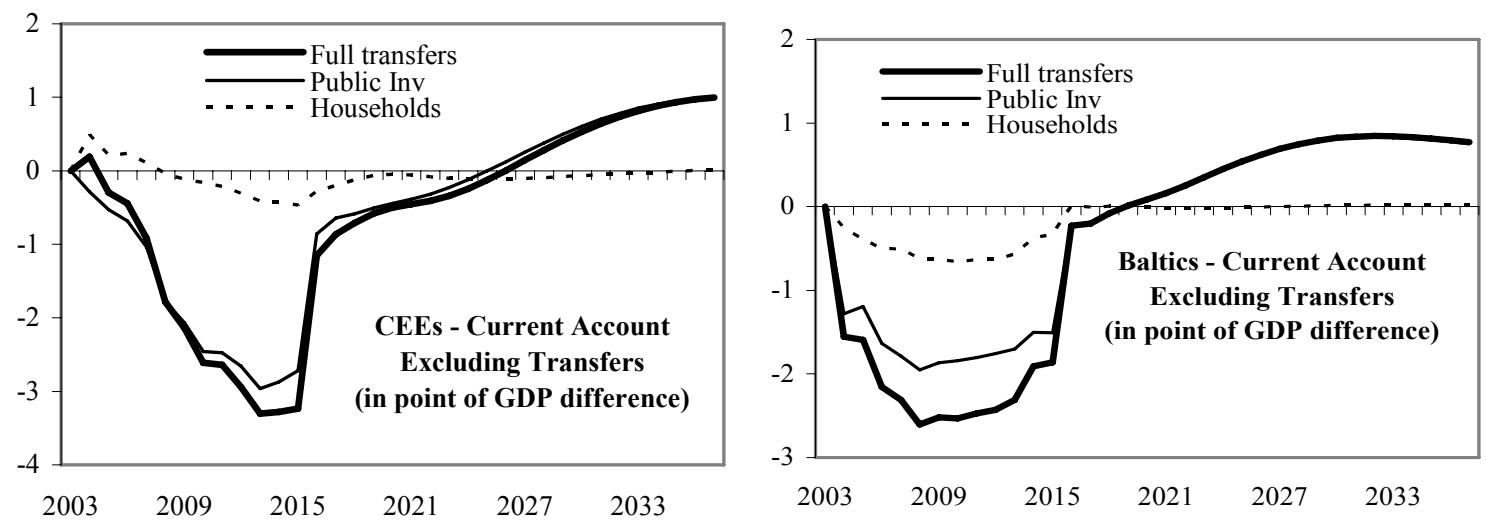

24. On the supply side, increased productivity would translate into higher production through stronger private investment effort in both the tradable and nontradable sectors, not through higher labor participation. With public investment raising corporate productivity, private firms would react by increasing the capital stock and their labor demand. Capital stock accumulation would initially be hindered by the increase in real interest rate, but once the latter dissipates, private investment would be stimulated in both the tradable and non tradable sector (see also Appendix Figure 4c). This would not the case for labor however: with increased labor productivity, firms would increase their labor demand, but households, feeling richer from the transfers, would not increase their labor supply. Wages would be driven up to clear the market, and overall, labor would only be marginally modified by the EU transfers. However, labor would temporarily shift away from the tradable sector to the non tradable sector, to fulfill higher demand in the non tradable sector, while imports of tradable goods would compensate for temporarily lower domestic tradable production. Of course, this result depends on the unemployment rate being close to its equilibrium level before EU fund inflows, a feature that is embedded in the model. Still, with many of the NMS economies currently nearing close to capacity limits, it is likely to be a reasonable approximation.
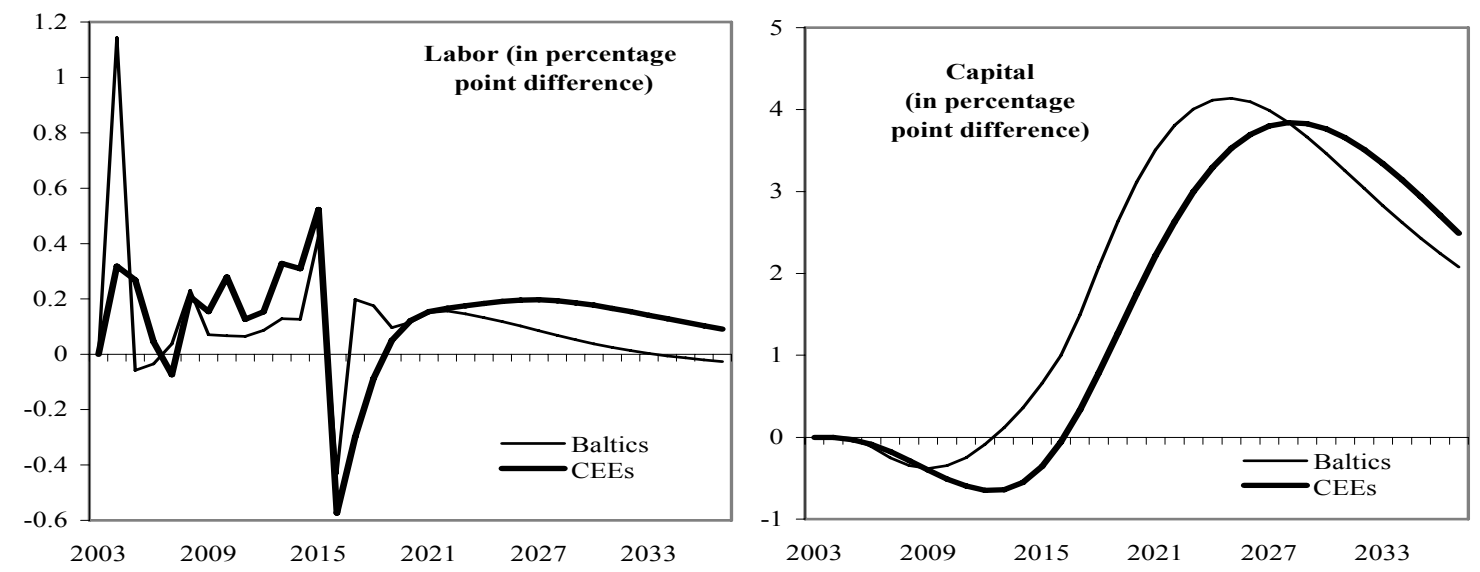

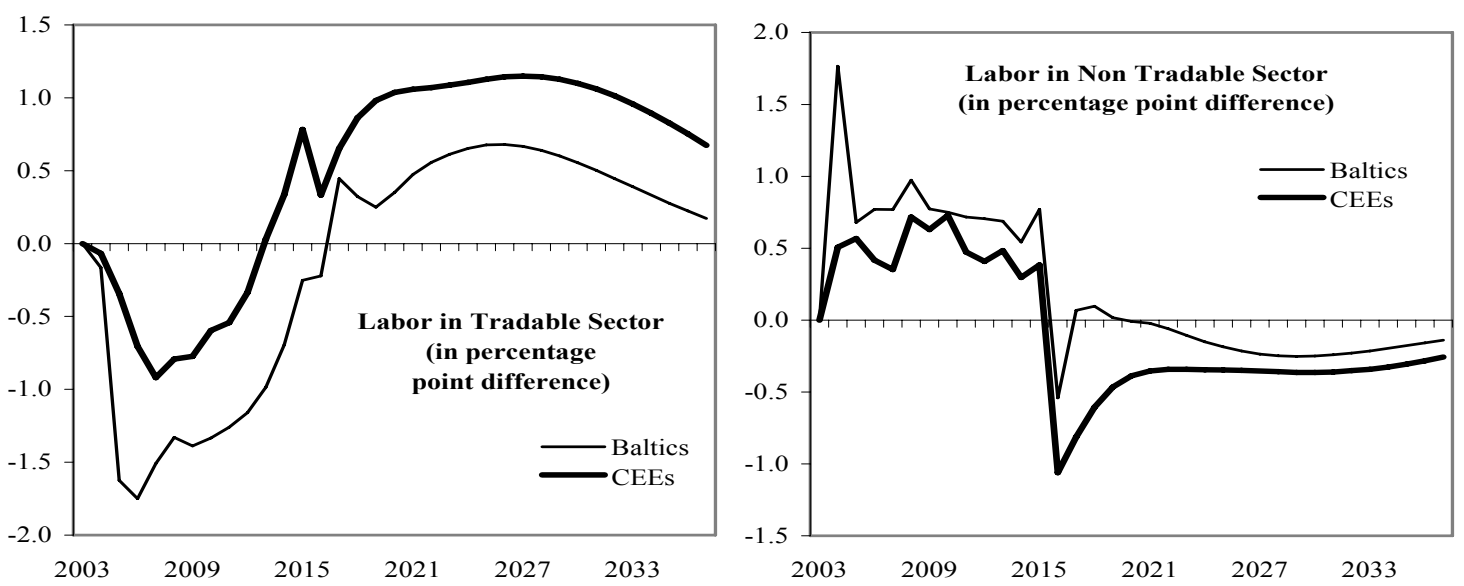

25. Still, EU funds would not necessarily lead to appreciation and Dutch disease.

Initially, and throughout the period of EU inflows, production would shift to the nontradable sector, and the internal real exchange rate (defined as the relative price of nontradable versus tradable price) would appreciate, as more of the domestic resources would need to be devoted to increase supply in nontradable goods. However, as the surge in public investment leads to an increase in competitiveness in the whole economy, fewer factors would be needed in the nontradable sector to fulfill demand, and production would shift back to the tradable sector, where the increased productivity would spur exports. In the meanwhile, the internal real exchange rate would gradually depreciate back to its value prior to the inflows. Obviously, the more EU funds would be devoted to public investment, the less likely the recipient country would be to get trapped into a Dutch disease phenomenon.
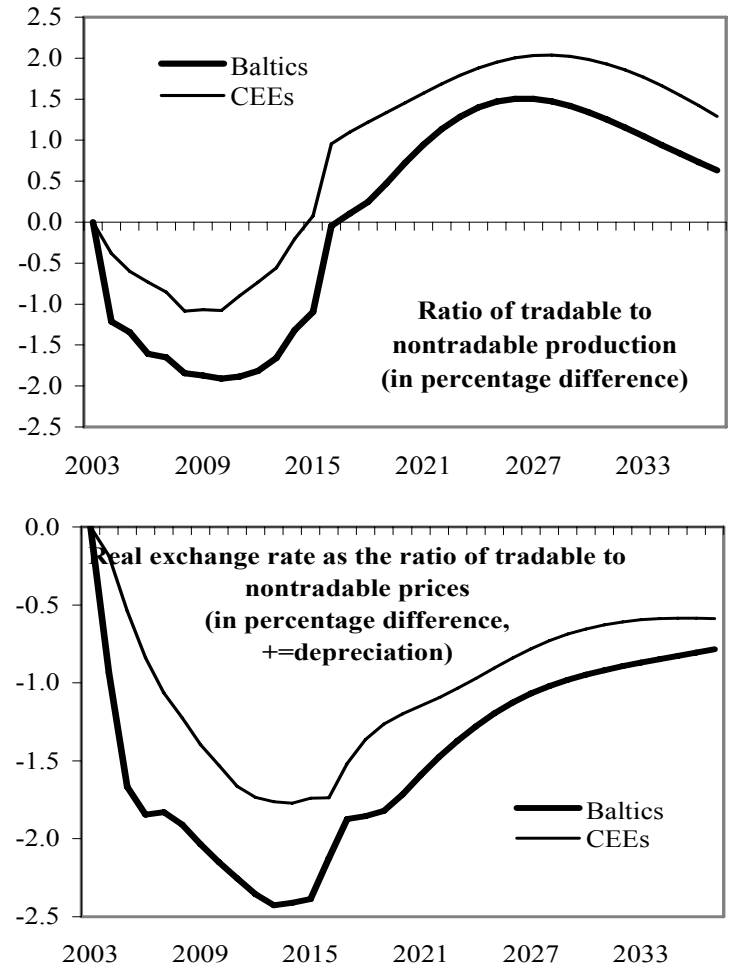


\section{Income convergence would be speeded up only because of EU-fund related} public investment. ${ }^{19}$ The EU fund inflows invested in public infrastructure would allow for a considerable acceleration in the catch-up process, by close to 5 percentage points of GDP in the early 2020s. Conversely, EU fund inflows supporting households' income would have virtually no impact on per capita GDP, because, as exemplified by the stylized cases discussed above, boosted consumption would be offset by a deteriorated corporate profitability, an appreciated real exchange rate, and lost competitiveness (See also Appendix Figures $5 b$ and $6 b$ ).

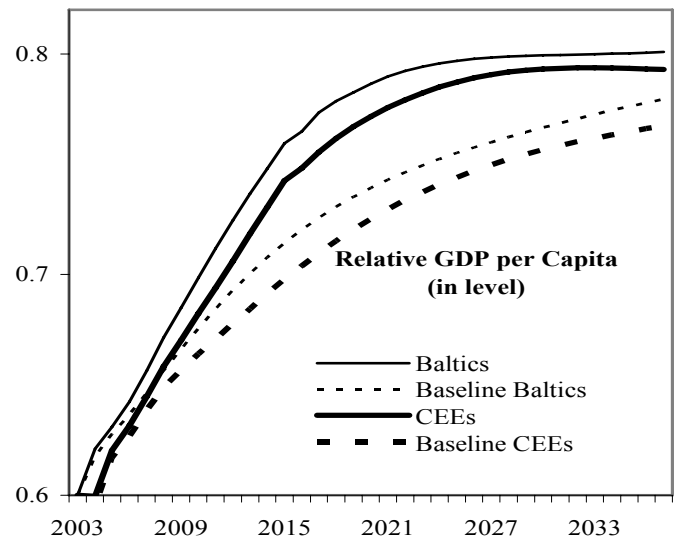

\section{Second, real variables behave similarly in both exchange rate regimes, but the} adjustment is achieved differently and at a different pace in each regime.

- In both the inflation targeting and the fixed exchange rate regimes, the real external exchange rate (defined as the ratio of domestic versus foreign prices) would briefly appreciate, before experiencing a sustained depreciation throughout the period of EU fund flows, as the positive productivity shock from EU- financed public investment gives these countries a competitive edge on

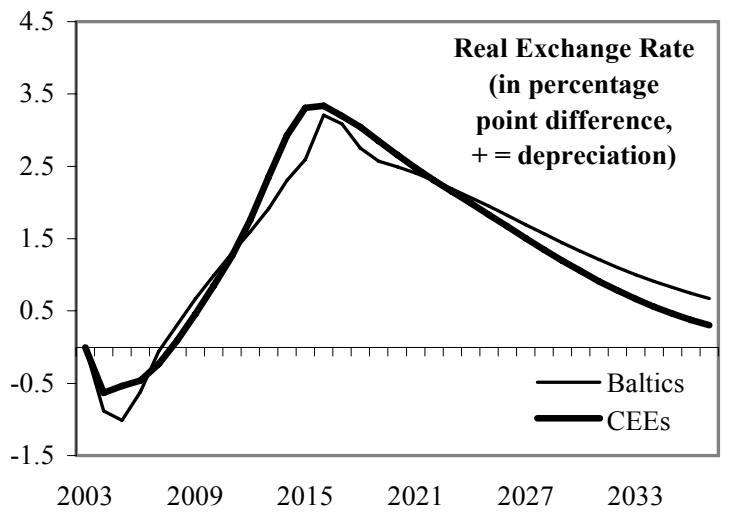
foreign markets. The way the real exchange rate depreciation would be achieved, however, would differ substantially across regions, depending on which parameters can move more quickly. In the inflation targeting regime, the nominal exchange rate can depreciate freely, whereas in the fixed exchange rate regime, prices have to bear the full adjustment. So, in the CEEs, the currency would depreciate, while in the Baltics, inflation would be subdued during the whole period of EU transfer inflows, as a way to achieve real depreciation.

\footnotetext{
${ }^{19}$ As mentioned above, the results are sensitive to the public sector investment productivity assumption, in particular the extent by which private investment is boosted. Still, results on income convergence are fairly robust: convergence is increased by 5 percentage points in the early 2020s in this scenario, where the elasticity of GDP to the public capital stock is assumed to reach 0.15 . With this elasticity at 0.2 , income convergence is boosted by 6 percentage points. Conversely, with this elasticity at 0.1 , income convergence is still boosted by 3 to 4 percentage points.
} 

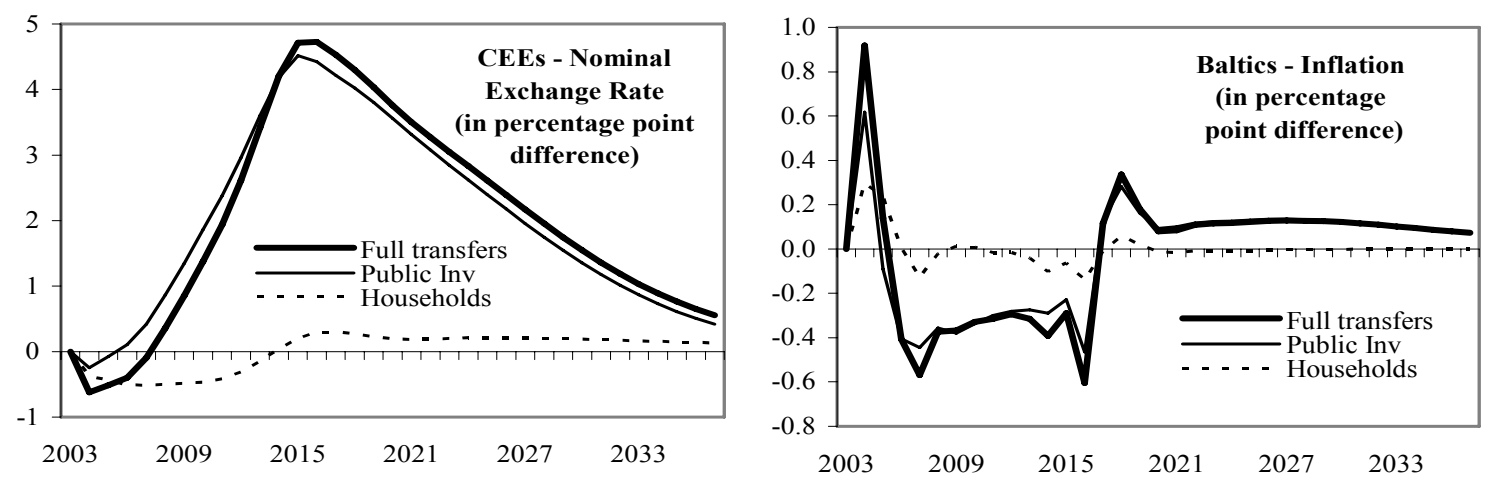

- Similarly, the real interest rate would increase in both regions, temporarily crowding out private investment, but because of difference in speed of adjustment, the real interest rate would increase slightly more rapidly in the Baltics than in the CEEs. The mechanisms at play would also differ between regions: with nominal interest rates set at foreign levels in the Baltics, the disinflation generated by the EU fund-related productivity shock would raise real interest rates. In inflation-targeting CEEs, the nominal exchange rate depreciation would generate price pressures that monetary policy makers would counteract by hiking nominal interest rates. As a consequence, private investment would be initially depressed by higher borrowing costs. However, this effect would be short-lived, as public investment would eventually boost private capital's marginal productivity.
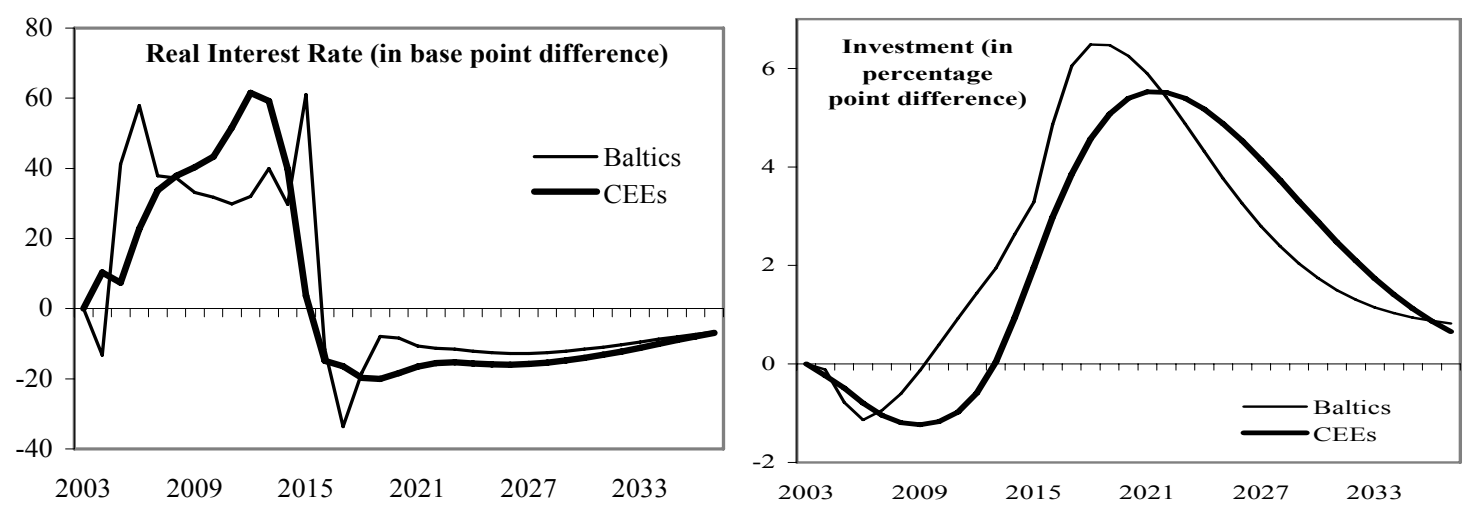

28. Inflation targeters would not benefit from modifying their monetary policy framework post $\mathrm{EU}$ funds inflows. In Central European countries, softening the inflation targeting regime to deal with short term pressures would end up being counterproductive: In their forward-looking behaviors, households would fully anticipate the shift in monetary policy approach, and eventually the monetary authorities would have to increase

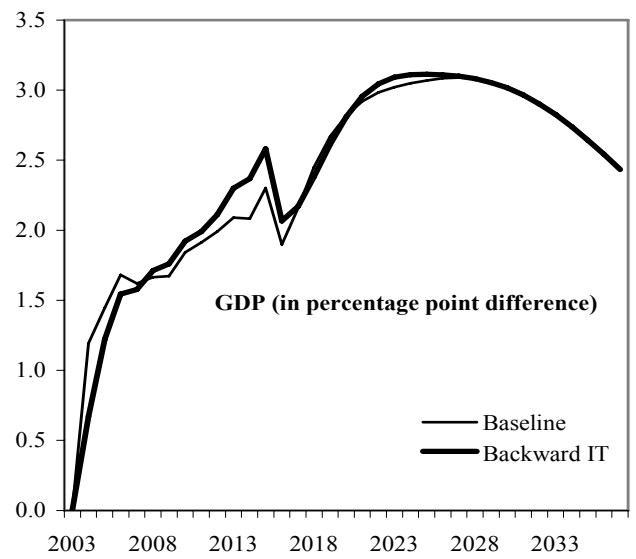


rates more sharply to counter-act a sharper rise in inflation, with no gains on the real economy. ${ }^{20}$ At the end, real interest rates would increase by as much as in the baseline scenario, and the impact of EU funds on the real economy would remain unchanged.

Therefore, while the monetary authorities should use the full range of the inflation targeting bands, they should be careful not to be perceived as loosening their mandate to accommodate for the EU fund impetus. If so, they only stand to loose credibility, which would have to be regained at the cost of tighter monetary policy.
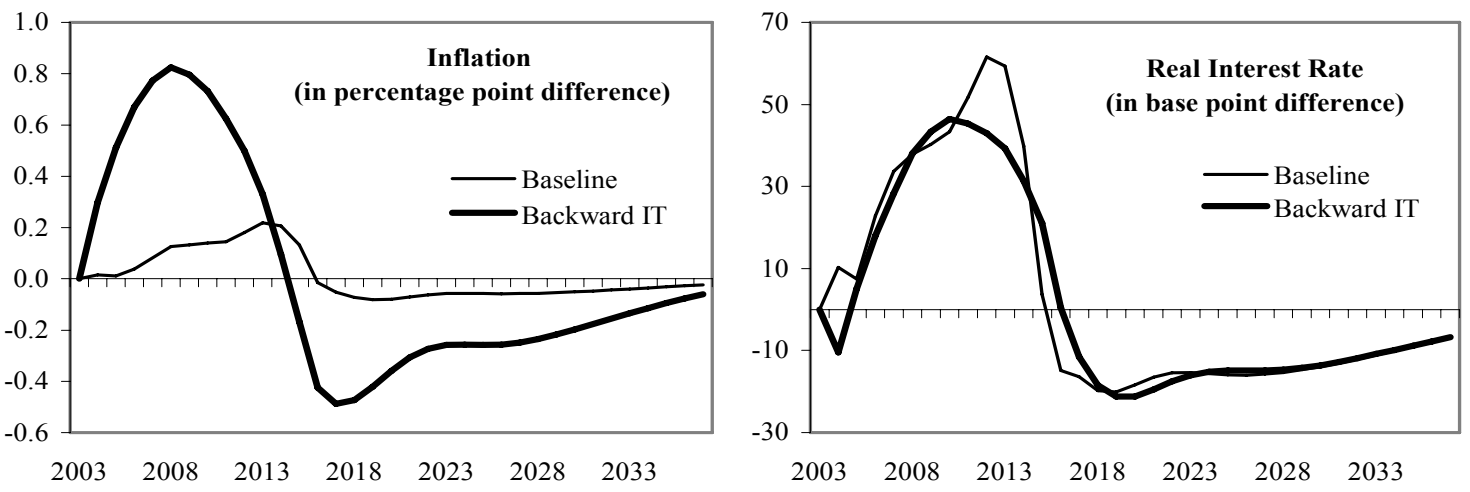

\section{Third, NMS countries would}

benefit from a counter-cyclical and conservative fiscal policy during the period of EU fund inflows for at least three reasons:

- Decreasing public debt. The full play of automatic stabilizers would allow for a decrease in public debt of at least 5 percentage points of GDP, if all additional temporary public revenue fiscal policy derived from the adjustment to the EU fund shock are saved and used to reduce public debt. Moreover, in the model, the permanent impact of the EU fund on the economy, induced by the higher productivity, enables a decline in tax rates of $2 / 3$ percentage point over the period 2003-15, but these cuts are

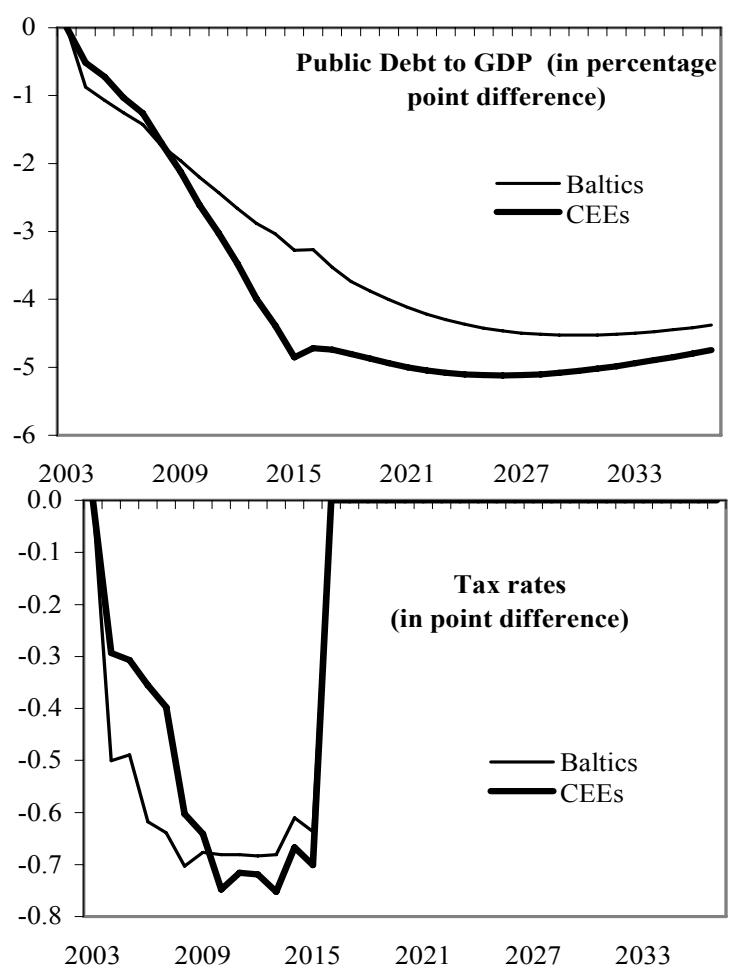

\footnotetext{
${ }^{20}$ In the model, the softening of the inflation targeting is modeled through a higher auto-regressive coefficient in the monetary policy reaction function, giving a larger impact to past nominal interest rate on current interest rate.
} 
reverted at the end of the fund inflow period. ${ }^{21}$ If the authorities were to forgo this change in taxation - as reverting the policy by 2015 could be costly - the fiscal consolidation concomitant with EU fund inflows could even be larger. Such a strategy would be particularly welcome in some of the Central European countries whose public debt ratio is hovering around the Maastricht criteria, as a relatively seamless approach to reduce debt to less vulnerable levels.

- Uncertainty about the efficiency of EU fund. There is still a large uncertainty surrounding the efficiency of EU funds and the exact private income support-public investment distribution of EU funds. The larger the share devoted to public investment, the more sustainable the boost to public revenue. However, if the authorities were to rely on these revenue, but EU funds to fund mostly income support, the fiscal position could end up being more deteriorated at the end of the period of EU fund inflows. The existing uncertainty should therefore warrant a cautious and conservative approach, where buoyant revenue in the upcoming ten years should be mostly saved. In countries where the public expenditure ratio to GDP is already high, one could even argue for a need to at least partially offset the increase in EU-funded public investment through cuts in other public spending.

- Exacerbated demand pressures under pro-cyclical fiscal policy (Figure 3). If, instead of letting the automatic stabilizers play fully as in the baseline scenario, the authorities would only target a stabilization of their debt to GPD ratio, fiscal policy, by allowing sharper and more permanent declines in tax rates, would de facto be expansionary. Such a policy would act like a demand shock, next to the supply shock provided by the EU funds. As a consequence, compared to the baseline scenario, the initial real appreciation would be stronger and more prolonged, as the domestic supply side would not be ready initially to serve an even larger surge in demand. The monetary reaction would also be stronger in inflation targeting countries, and inflation less subdued in fixed exchange rate regime countries. At the end, the real interest rate tightening would be strengthened by the pro-cyclical policy. On the real front, the substantial lift in consumption compared to the counter-cyclical fiscal policy scenario would be fully (in the case of the Baltics) or even more than fully (in the case of Central Europe) offset by a stronger crowding out in private investment and the more appreciated currency. In both regions, the countries would be worse off in terms of convergence.

\footnotetext{
${ }^{21}$ It is not possible to simulate the impact of the EU fund inflow while leaving tax rate unchanged in GIMF, as this fiscal policy does not necessarily insure long term convergence. An anchoring fiscal target - either fiscal balances or a debt target in the pro-cyclical policy exposed later - is required.
} 


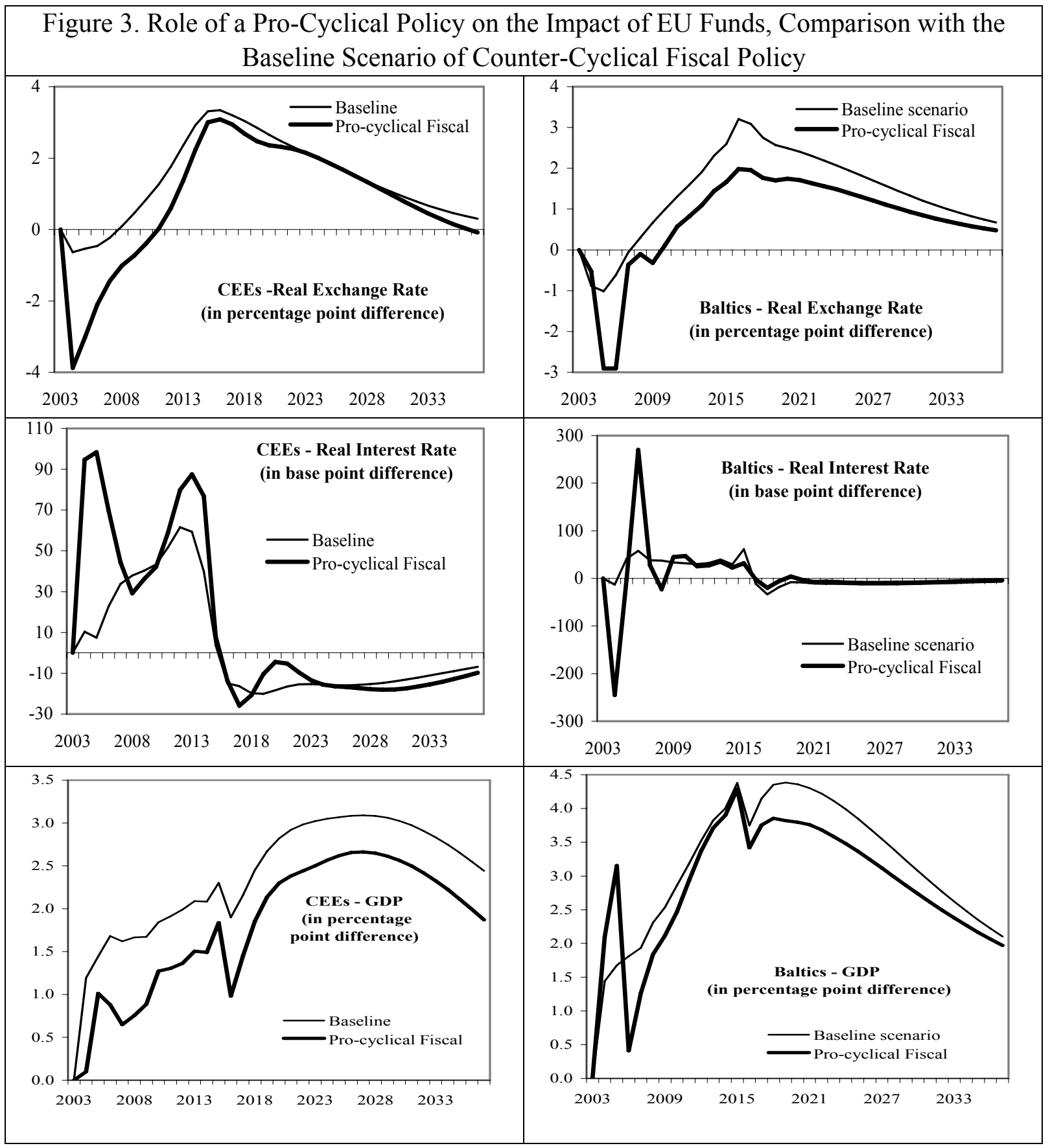

\section{E. Conclusion}

\section{New Member States stand to benefit greatly from EU fund inflows in the next}

ten years. EU fund inflows could boost GDP per capita relative to the EU by as much as 5 percentage points, therefore substantially accelerating the ongoing convergence process. Still, such benefits should not be taken for granted, and the authorities would need to set the right institutional and policy framework to avoid potential pitfalls. 
31. This study provides three policy lessons to take full advantage of the opportunity afforded by EU funds:

- The EU funds need to be directed predominantly to public investment rather than to income support, a prerequisite for the derived lift in overall productivity to speed up the convergence process. In addition, the focus on the supply side would guarantee that this occurs without undue pressures on monetary policy or prices and avoid the risk of a Dutch disease. In sharp contrast, the effect of funds directed to income support would be short-lived and would fail to deliver benefits in terms of additional convergence.

- At the end of the day, real variables would be affected similarly in both exchange rate regimes. In particular, the EU fund inflows would lead to a depreciation of the real equilibrium exchange rate in the medium-run, if indeed funds are used to bolster supply, and the real interest rate would increase during the period of inflows. The only differences would be in the pace of adjustment, foreseen as slightly more rapid in the Baltics, and in the variables at play in the adjustment: In the CEEs where the currency floats freely, the equilibrium nominal exchange rate would depreciate, while in the Baltics, the real exchange rate depreciation would be achieved through lower inflation. Still, in both regimes, the larger the share of EU funds directed to income support, the greater the risks of stoking a demand boom in the region, and thereby reinforcing overheating forces and generating real appreciation pressures.

- To best accompany the EU fund inflows the policy-mix would have to combine conservative and counter-cyclical fiscal policy with a strong commitment to the existing monetary regime. Neither a more accommodative fiscal policy nor a softening in monetary policy commitment would provide any additional boost to the real economy. On the contrary, a more pro-cyclical policy would run the risk of boosting unduly the demand side, with a build-up in either inflationary or monetary pressures that would eventually hold convergence back. In inflation-targeting countries, a more backwardlooking monetary policy would eventually result in sharper interest rate hikes to counteract higher price pressures, with no effect on the real side. 


\section{REFERENCES}

Angel de la Fuente, Convergence across Countries and Regions: Theory and Empirics, Instituto de Análisis Económico (CSIC), November 2002

Barry and others, "The Single Market, the Structural Funds and Ireland's Recent Economic Growth," in Journal of Common Market Studies (Sept 2001) Vol. 39 No. 3 pp. 53752

Bayoumi T., D. Laxton, and P. Pesenti, (2004), "Benefits and Spillovers of Greater Competition in Europe: A Macroeconomic Assessment," ECB Working Paper 341.

Boldrin, M. and F. Canova (2001), "Inequality and convergence in Europe's regions: reconsidering European regional policies," Economic Policy, Vol. 16, Isssue 32, April 2001, pp.205-53.

Boldrin, M. and F. Canova (2003), "Regional Policies and EU enlargement", CEPR Discussion Paper Series No. 3744.

Bradley J., (2002), "An Examination of the Ex-Post Macroeconomic Impacts if CSF 199499 on Objective 1 Countries and Regions, ESRI (Ireland), December 2002.

Bradley J, (2005), "Promoting Cohesion in the Enlarged EU: Is There A Role For National Development Plans?," Chapter 8 in Integration, Growth and Cohesion In An enlarged European Union, by Bradley J., Petrakos G., and Traistaru I., editors, New York: Springer, 2005, pp. 173-205.

Bradley (2007) Evaluation for Estonia.

Bradley J. and others, (2005a), "HERMIN: A Macro Model Framework For the Study of Cohesion and Transition," Chapter 9 in Integration, Growth and Cohesion In An enlarged European Union, by Bradley J., Petrakos G., and Traistaru I., editors, New York: Springer, 2005, pp. 207-241.

Bradley J. and others, (2005b), "Macro Impact Evaluation of National Development Plans: Ireland and Estonia," Chapter 10 in Integration, Growth and Cohesion In An enlarged European Union, by Bradley J., Petrakos G., and Traistaru I., editors, New York : Springer, 2005, pp. 243-274.

Bradley J., Zaleski, Tomaszewski and Zembaty, (2006), "Evaluating the Combined Impact of NDP 2004-06 and NSRF 2007-13: An Analysis Based on the polish HERMIN Model," Wroclaw Regional Development Agency, Working Paper March 2006. 
Brock, P., (1996), "International Transfers, the Relative Price of Non-Traded Goods, and the Current Account," in The Canadian Journal of Economics, vol. 29, No. 1 (February), pp. 163-180).

Bulir, A., and T. Lane, (2004), "Aid and Fiscal Management," in Helping Countries Develop: The Role of Fiscal Policy, by Gupta S., Clemens B., and Inchauste G., editors, Washington DC: International Monetary Fund, pp. 422-451.

Cappelen A and others, (2003), "The Impact of EU Regional Support on Growth and Convergence in the European Union," Journal of Common Market Studies, Vol. 41, No 4, pp. 621-644.

Corrado, L., R. Martin and M. Weeks (2005) Identifying and Interpreting Regional Convergence Clusters across Europe, Economic Journal 115 (March) pp. C133C160.

Devereux M.and G. Smith, (2005), “Transfer Problem Dynamics: Macroeconomics of the Franco-Prussian War Indemnity," Queen's University, Department of Economics, Working Paper No. 1025

Easterly, W., (2003), "Can Foreign Aid Buy Growth?,” in The Journal of Economic Perspectives, Vol. 17, No. 3, pp. 23-48.

European Commission (2006), “Allocation of 2005 EU Expenditure by Member State," Directorate-General Budget, available at:

http://ec.europa.eu/budget/library/documents/revenue_expenditure/agenda_2000/allo crep_2005 en.pdf

European Commission (2007), "The Impact of Cohesion Policy," Chapter 2 of Growing Regions, Growing Europe, Fourth Report on Economic and Social Cohesion, pp 95133

http://ec.europa.eu/regionalpolicy/sources/docoffic/official/reports/cohesion4/indexen .htm.

Everdeen and others, (2003), "Funds and Games," ENEPRI Occasional Paper No. 3, October 2003.

Everaert L., W. Schule, (2006) "Structural Reforms in the euro Area: Economic Impact and Role of Synchronization Across Markets and Countries," IMF Working Paper No. 06/137.

Fagerberg, J., and B. Verspagen (1996), "Heading for divergence? Regional Growth in Europe Reconsidered," in Journal of Common Market Studies, 34(3), pp. 431-48 
Fayolle J. and A. Lecuyer, (2000), “Croissance Régionale, Appartenance Nationale et Fonds Structurels Européens: Un Bilan d'Étape,” Revue de l’OFCE (73), pp. 165-196.

Garcia-Solanes J. and R. Maria-Dolores, (2001), "The Impact of Structural Funds on Economic Convergence in European Countries and Regions," Convergence Issues in the European Union, 2002, pp. 61-82, Cheltenham, U.K. and Northampton.

Gaspar, V. and A.M. Pereira (1995), “The Impact of Financial Integration and Unilateral Public Transfers on Investment and Economic Growth," Journal of Development Economics, 48(1), pp. 43-66.

Gaspar V. and A. N. Leite, (1994), "Cohesion and convergence: The Economic Effects of EC Structural Transfers, Economia,” 18(0), pp 87-108.

Genberg, H. (2005), “The Macroeconomic Effects of Adjustment Lending: A Review and Evaluation," in The Journal of Policy Reform, Vol. 8, No. 1, pp. 1-40.

Goybet, P. and M. Bertoldi (1994), "The Efficiency of the Structural Funds," in Improving Economic and Social Cohesion in the European Community, J. Mortensen, editor, New York: St Martin's Press, pp. 229-40

Kumhof, M. and D. Laxton, 2007a, "A Party without a Hangover? On the Effects of U.S. Government Deficits,” IMF Working Paper No. 202 (Washington: International Monetary Fund).

Kumhof, M. and D. Laxton, 2007b, “The Global Integrated Monetary and Fiscal Model (GIMF)," mimeo (Washington: International Monetary Fund).

Kumhof, M. and D. Laxton, 2007c, “Chile's Structural Fiscal Surplus Rule: A Model-Based Evaluation," Chile-Selected Issues Paper, Country Report No. 07/332 (Washington: International Monetary Fund).

Lighart J. and R. Suarez (2005), “The Productivity of Public Capital: A Meta Analysis?,” Lolos (2001), "The Macroeconomic Effect of EU Structural Transfers on the Cohesion Countries and Lessons for the CEECs," Interim Report No. IR-01-044 (October), International Institute for Applied Systems Analysis: Austria.

Lolos, Suwa-Eisenmann, Zonzilo, Bourgignon (1995), "Evaluating the CSF With an Extended Computable General Equilibrium Model: The Case of Greece (19881995)," in Journal of Policy Modeling 17(2) pp. 177-197.

Lolos and Theodoulides (2001), "The Role of EU structural Funds in the Development of Lagging Behind European Regions," in Economic and Financial Modeling, Vol 8, 
No. 1 pp. $29-46$

Magyar Nemzti Bank, (2006), "The Impact of EU Funds on Potential Growth," Chapter 2 in the Report on Convergence, pp. 49-65, December 2006.

Martin, R. and P. Sunley, (1998) "Slow Convergence? The New Endogenous Growth Theory and Regional Development," Economic Geography, Vol. 74, No. 3, pp. 201-227

Pereira A.M. (1997), "Development Policies in the EU: An International Comparison," Review of Development Economics, 1(2) pp. 219-35.

Pereira and Gaspar (1999), "An Intertemporal Analysis of Development Policies in the EU," in Journal of Policy Modeling 21(7) pp. 799-822

Rassekh, F. (1998), “The Convergence Hypothesis: History, Theory, and Evidence,” in Open Economies Review Vol.9, pp. 85-105

Roger, (1996), "Macroeconomic Evaluation of the Effects of Community Structural Funds (CSF) With QUEST II, Paper prepared for the European Conference on Evaluation Methods for Structural Funds Intervention, Berlin,” December 2-3, 1996.

Roger and In't Veld, (2002), "Some Selected Simulation Experiments With the European Commission's QUEST Model," European Community DGEcFin No. 178, October 2002.

Rosenberg, C., R. Sierhej (2007), "Interpreting EU Funds Data for Macroeconomic Analysis in the New Member States," IMF Working Paper No. 07/77.

Tondl, Gabriele(1998), The Changing Pattern of Regional Convergence in Europe. Robert Schuman Centre (EUI), RSC No. 97/53. Available at SSRN: http://ssrn.com/abstract $=130688$ or DOI: $10.2139 /$ ssrn.130688

Temple, J. (1999), “The New Growth Evidence,” Journal of Economic Literature, vol. XXXVII (March 1999) pp.112-56

Tressel, Thierry (2007), “Is There a Foreign Aid Paradox?," IMF Research Bulletin, Vol. 8, No. 4, (December 2007). 


\section{APPENDiX I. EU Funds: What Is In The OfFING?}

EU funds to the NMS serve multiple purposes, ranging from income convergence to agricultural support. This is achieved by a myriad of individual programs which can be classified in three main categories (Rosenberg and Sierhej, 2007):

- Agriculture support: these initiatives are part of the Common Agricultural policy available to the NMS. They provide price subsidies, direct payments to farmers, and support to rural development and fisheries.

- Structural Funds: these aim at promoting catch-up in less developed regions, and at supporting areas with structural difficulties.

- Cohesion Funds: these are available to countries with GDP below 90 percent of the EU average and directly support projects in infrastructure and environment.

Appendix Figure 1. Average EU Funds Spending (percent of GDP) 1/
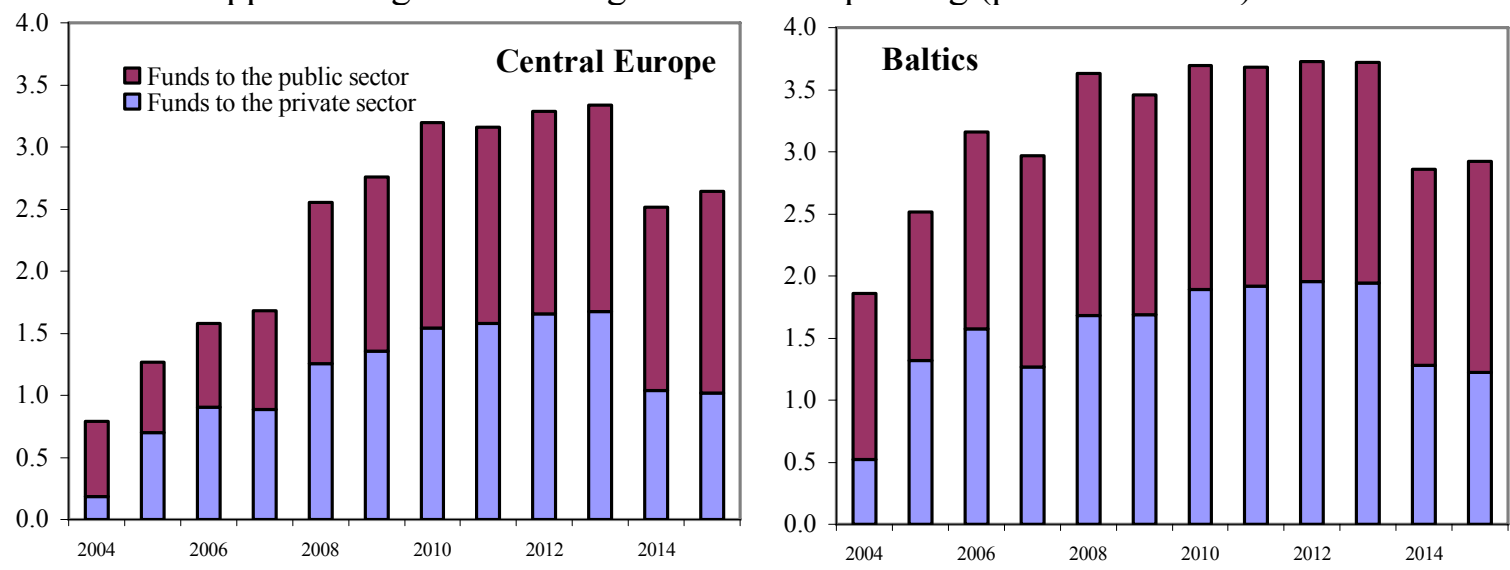

Source: Rosenberg and Sierhej (2007); IMF WEO.

1/ The aggregation is derived from a simple average. Countries in the Central Europe group are the Czech Republic, Hungary, Slovakia and Slovenia. Countries in the Baltics group are Estonia, Latvia and Lithuania.

Inflows from the EU could reach 4 percent of GDP per year in the beginning of the next decade in most of the NMS (Appendix Figures 1, 3a and 3b). ${ }^{22}$ Annual inflows have been gradually increasing since accession, to reach in 2006 on average $1 \frac{1}{2}$ percent of GDP in Central Europe and 3 percent of GPD in the Baltics. But with the 2004-06 plan disbursement

\footnotetext{
${ }^{22}$ All EU funds-to-GDP ratios use the following data: EU fund nominal commitments are constructed using the amounts in euros in constant 2004 prices provided by the European Union and elements of national strategies for the period 2007-13, to which a 2 percent annual deflator is applied (following the practice of the EC and member countries). Future inflows are taken from Rosenberg and Sierhej (2007). Nominal GDP and bilateral exchange rates are taken from the IMF's WEO projections. The breakdown between public and private recipients is based on information from the Czech, Hungarian and Slovenian authorities. For more details, see Rosenberg and Sierhej (2007).
} 
coming to an end in 2008, inflows are expected to rise dramatically that year in Central Europe, where absorption so far has been relatively low, as the authorities will strive not to lose any amount to which they were entitled under that plan. Rosenberg and Sierhej (2007) forecast that by then EU transfers to Central Europe will average 2 $1 / 2$ percent of GDP, and gradually rise to $3 \frac{1}{2}$ percent of GDP over the following five years, while they will hover around $3-3 \frac{1}{2}$ percent of GDP in the Baltics. The breakdown between private (largely farmers) and public recipients is close to even.

Appendix Figure 2. EU Funds Payments and Relative GDP per Capita 1/

\section{EU funds are projected to flow in to NMS} more gradually than was the case for previous accessing countries, but GDP per capita relative to older members is also much lower (Appendix Figure 2). The profile of inflows is back-loaded for the current NMS, whereas new entrants in the early 90s, like Spain, Greece and Portugal as well as Ireland - received the highest amounts in the first two years of accession, at close to 5 percent of GDP. The current
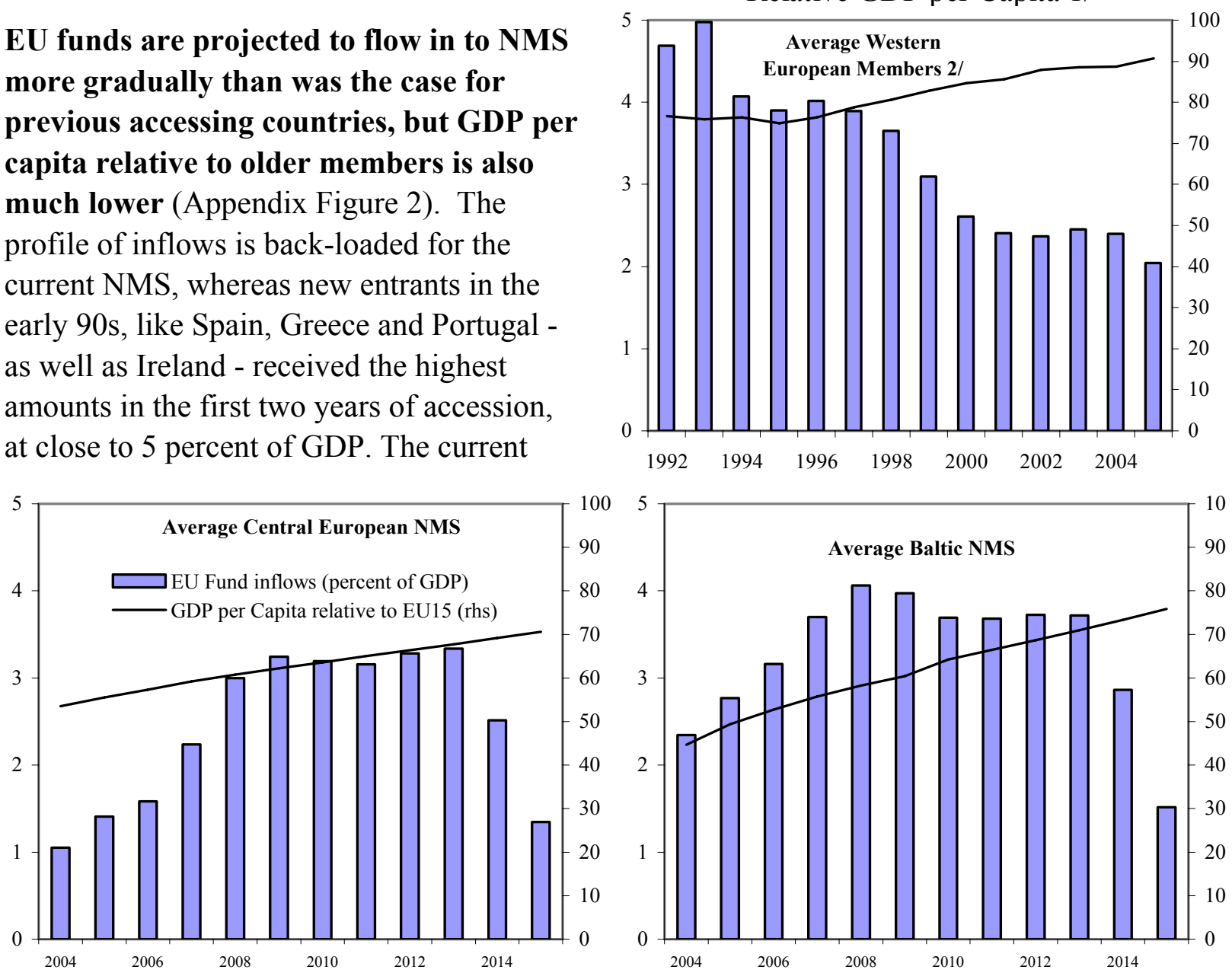

Source: European Commission (2006), Eurostat, Rosenberg and Sierhej (2007), IMF WEO.

1/ EU expenditures excluding administrative expenditures for Western European Members; EU payments including advances to Central European NMS.

slow pattern in some of the NMS is at least partly related to slow absorption rates and administrative bottlenecks, itself possibly linked to the relatively low initial relative GDP per capita: while in 1992, the large EU recipient countries' GDP per capita reached on average 75 percent of the euro area, it was about 50 percent only in the Central European NMS and 45 percent in the Baltics in 2004. 
Appendix Figure 3a. Central Europe: EU Funds Spending, 2004-15
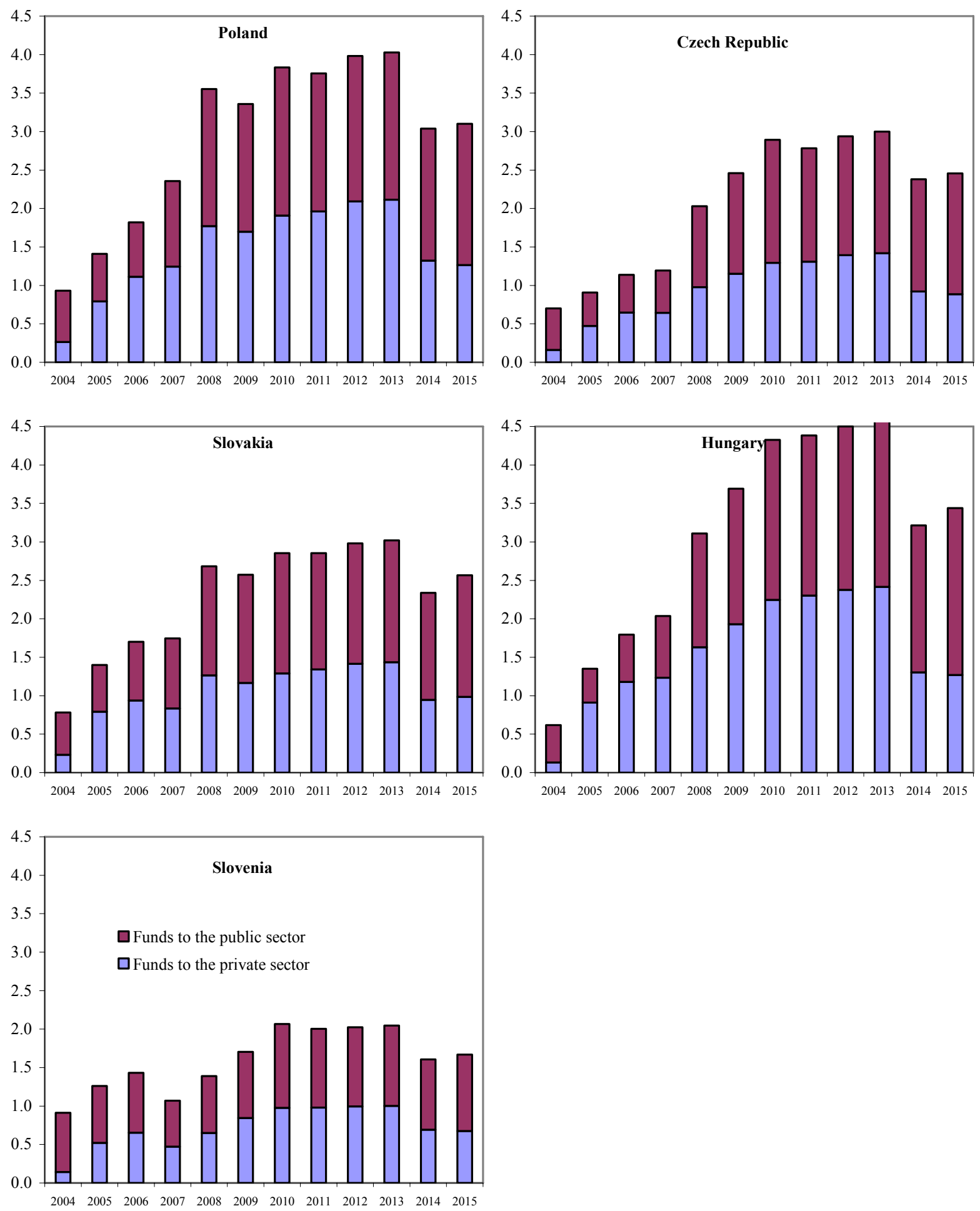

Source: Rosenberg and Sierhej (2007), IMF WEO 
Appendix Figure 3b. Baltics: EU Funds Spending, 2004-15
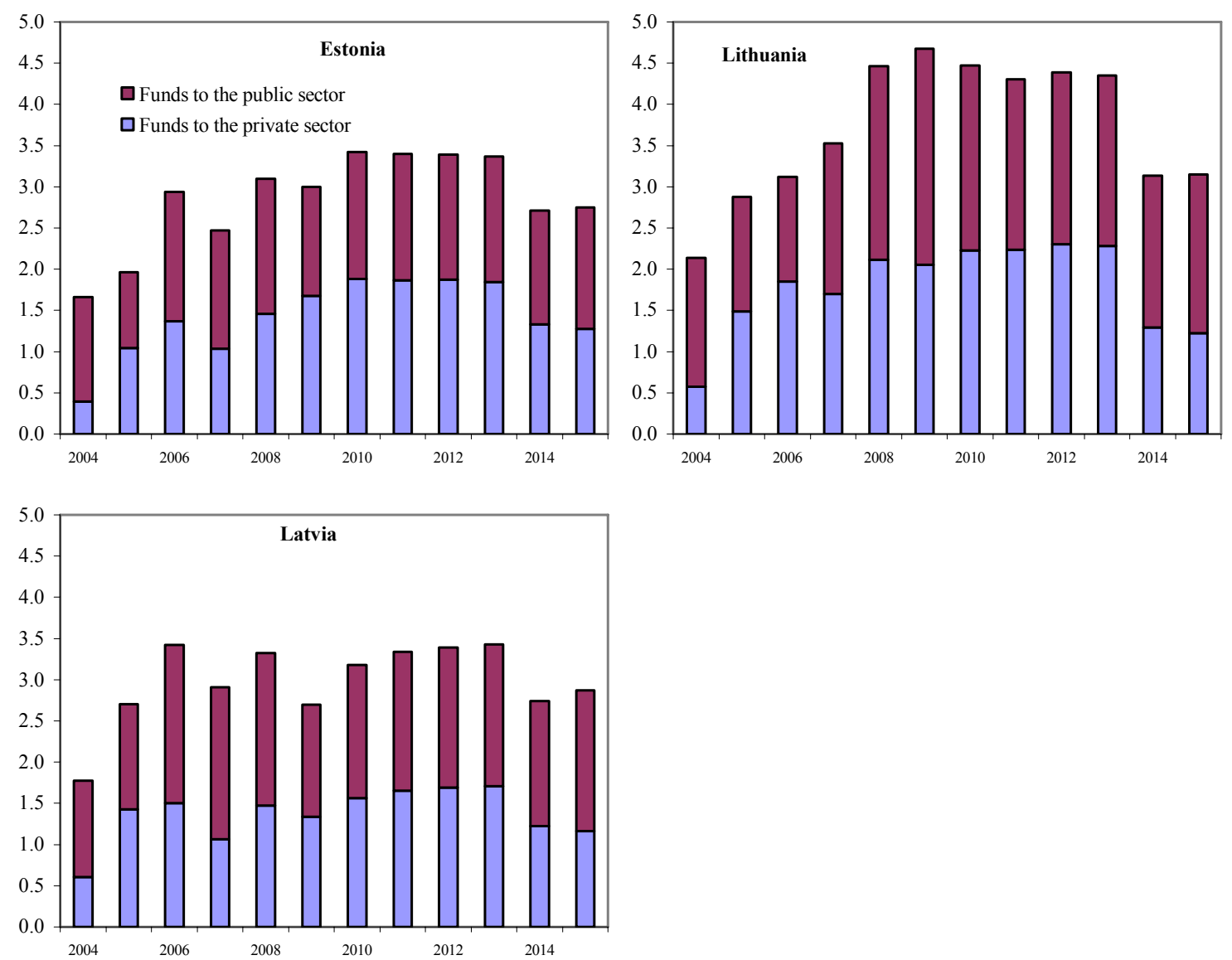

Source: Rosenberg and Sierhej (2007), IMF WEO 


\section{APPENDIX II. MODIFICATIONS TO GIMF}

We are using here a version of the model that was available within the IMF in May 2007. It is derived from the version of the model used in Kumhof and Laxton (2007c), the "Chilean model" with contra-cyclical fiscal policy, in which the frequency was changed from quarterly to annual, and the raw commodity sector removed.

\section{Introducing Convergence: Exogenous productivity shock}

To generate the convergence baseline, the model is first calibrated in its steady state mode with the parameters described in Appendix III, and with the level of total factor productivity in the tradable sector in the home country (NMS potentially recipient of EU funds) at 45 percent of the one prevailing in the rest of the world (taken as the EU15).

The shock generating the convergence path that serves at the baseline for the EU fund shock consists of the following:

- The long-term total factor productivity in the tradable sector of the home country (A_T_HO_SS) is risen from 45 percent to 80 percent of the level of the rest of the world.

- Trade elasticities for both the home country (XI_D_HO and XI_T_HO) and the rest of the world(XI_D_RW and XI_T_RW) are gradually risen from 1.5 to 3.5. This change captures the increasing trade as the NMS converge towards average old EU members.

\section{Modeling EU Funds Transfers}

Home country external balance as well as households' and government's budgetary constraints were modified to reflect the inflows of EU funds. In addition, since the EU funds are defined in euros, namely the currency of the rest of the world, the impact of potential exchange rate evolution once the EU funds flow in was embedded, as EU funds were expressed in the national currency (value in euros multiplied by the nominal exchange rate):

- The home country's external balance was improved by the full amount of the EU transfers.

- The households' budgetary constraint was improved by the amount of EU funds devoted to the private sector. It was assumed that optimizing households and liquidity-constrained households would each receive a share of the funds proportionate to their share in overall population.

- The government's budgetary constraint was improved by the amount of EU funds devoted to the public sector, but with the rule that this amount is fully and immediately spent on public investment. None of the other expenditures are modified, and tax rates are only modified for the part of the fiscal improvement that is 
permanent (contra-cyclical fiscal rule). In addition, the overall increase in public investment also include a 15 percent co-payment paid by the government.

Given the positive externality expected from the EU-funded public investment projects, mainly in the infrastructure sector, we have added an endogenous impact of public investment on productivity: the exogenous overall TFP (A_HO) is endogenized, and made function of a long-term overall TFP (A_HO_SS) through an auto-regressive relationship. The long-term TFP is itself related to the overall stock of public capital (KG1_HO, derived from public investment) with an elasticity of 0.1 :

LOG(A_HO_SS $)=$ ALPHA_A_HO_SS * LOG $(\mathrm{KG1} 1 \mathrm{HO})+\mathrm{CONST}$ _A_HO_SS, with ALPHA_A_HO_SS $=0.1$.

Given that the stock of private already enters the production function as a productive factor (alfa_KG1_HO, calibrated at 0.1), it means that the overall elasticity of GDP to public capital stock amounts to 0.2. This corresponds to the upper limit in Lightart and Suarez (2005), who estimate it to range from 0.14 to 0.2 . 


\section{APPENDiX III. LiST OF PARAMETERS USED FOR THE CALIBRATION OF THE MODEL}

\begin{tabular}{|c|c|c|c|}
\hline & CEEs & Baltics & EU15 \\
\hline \multicolumn{4}{|l|}{ Ratios to GDP } \\
\hline \multicolumn{4}{|l|}{ Labor Income Share } \\
\hline In Total Economy & 54.0 & 51.5 & 60.3 \\
\hline In Non Tradable Sector & 58.6 & 56.4 & 65.9 \\
\hline Investment Share & 25.0 & 28.7 & 18.4 \\
\hline Exports of Final Goods & 21.5 & 15.9 & - \\
\hline Exports of Intermediate Goods & 26.4 & 21.7 & - \\
\hline Imports of Final Goods & 19.9 & 25.5 & - \\
\hline Non Tradable Production & 61.2 & 61.4 & 71.9 \\
\hline Net Financial Asset Position & -40.7 & -66.7 & - \\
\hline \multicolumn{4}{|l|}{ Fiscal And Monetary Parameters } \\
\hline & \multicolumn{3}{|c|}{ (in percent of GDP) } \\
\hline Government Expenditures & 21.6 & 19.2 & 22.0 \\
\hline Government Consumption & 17.8 & 15.4 & 19.7 \\
\hline Government Investment & 3.8 & 3.8 & 2.3 \\
\hline Government Social Transfers & 21.6 & 14.0 & 23.5 \\
\hline \multirow[t]{2}{*}{ Government Debt } & 37 & 32 & 66 \\
\hline & \multicolumn{3}{|c|}{ (in percent) } \\
\hline \multicolumn{4}{|l|}{ Share In Total Revenue of ... } \\
\hline Consumption Tax & 36 & 38 & 28 \\
\hline Capital Tax & 4 & 4 & 7 \\
\hline Labor Tax & 25 & 25 & 25 \\
\hline Lump-Sum Transfers & 35 & 33 & 40 \\
\hline Share of Cyclical Revenue Saved 1/ & 100 & 100 & 100 \\
\hline Inflation Target (annual) & 2.5 & - & 2.0 \\
\hline Coefficients In The Monetary Policy Reaction Function & \multicolumn{3}{|c|}{ (in level) } \\
\hline Lagged Nominal Interest Rate & 0.0 & 0.0 & 0.0 \\
\hline Inflation & 2.5 & 0.0 & 2.5 \\
\hline GDP Growth & 0.1 & 0.0 & 0.1 \\
\hline Output-Gap & 0.0 & 0.0 & 0.0 \\
\hline Exchange Rate & 0.0 & 1000000 & 0.0 \\
\hline
\end{tabular}

1/ This corresponds to a fiscal rule that stabilizes the structural fiscal balance. 


\section{Households' parameters}

Share of Liquidity Constrained Consumers

$\begin{array}{ccc}0.45 & 0.45 & 0.25 \\ 0.75 & 0.75 & 0.75 \\ 1 / 29.5 & 1 / 161.7 & 1 \\ 0.4 & 0.4 & 0.4 \\ 0.98125 & 0.98125 & 0.98125 \\ 0.95 & 0.95 & 0.95 \\ 4 & 4 & 4\end{array}$

Population Growth Rate (annual)

Population Ratio

Habit Persistence

Probability of Surviving (quarterly) 1/

Income Decline Rate (quarterly) 2/

Coefficient of Relative Risk Aversion

\section{Rigidities And Competition Parameters}

Price Adjustment Costs (annually)

Unions

Distributors

Non Tradable Sector

Tradable Sector

Imported Final Goods

Imports Intermediary Goods

Quantity Adjustment Costs

\section{Retail Sector}

Trade Flows of Final Goods

Trade Flows of Intermediary Goods

Capital Stock

Investment

Elasticities Of substitution Between Varieties 3/

Non tadable Sector

Tradable Sector

Retail Sector

Distribution Sector

Unions

$2 /$ This parameter captures the decline in revenue at the end of the life cycle

3 / The larger the elasticity $(\sigma)$ the smaller the market power of agents, and the lower the mark-up of prices charged over marginal costs $(\sigma /(\sigma-1))$. An elasticity of 21 corresponds to a mark-up of 5 percent, an elasticity of 41 to a mark-up of 2.5 percent. 
Production parameters

Real World Growth Rate (annual) 1.5

(in percent)

Real World Interest Rate (annual)

Depreciation Rates of... (annual, in percent)

Private Capital Stock

$-$

Public Capital Stock

10

10

10

Public Consumption Stock

Elasticity of GDP to ...

Public Capital Stock 1/

0.15

(in level)

Public Consumption Stock 1/

Elasticity of Substitution Between ...

Private Ouput and Public Capital

Domestic and Foreign Goods

Labor and Capital in the Tradable Sector

Labor and Capital in the Non Tradable Sector

Domestic Tradable and Non Tradable Goods

$1 /$ A 10 percent rise in public capital (resp. consumption) stock would increase GDP by 1.5 (resp. 0.1) percent. 
Appendix Figure 4a. EU Fund transfer shock, 2003-40
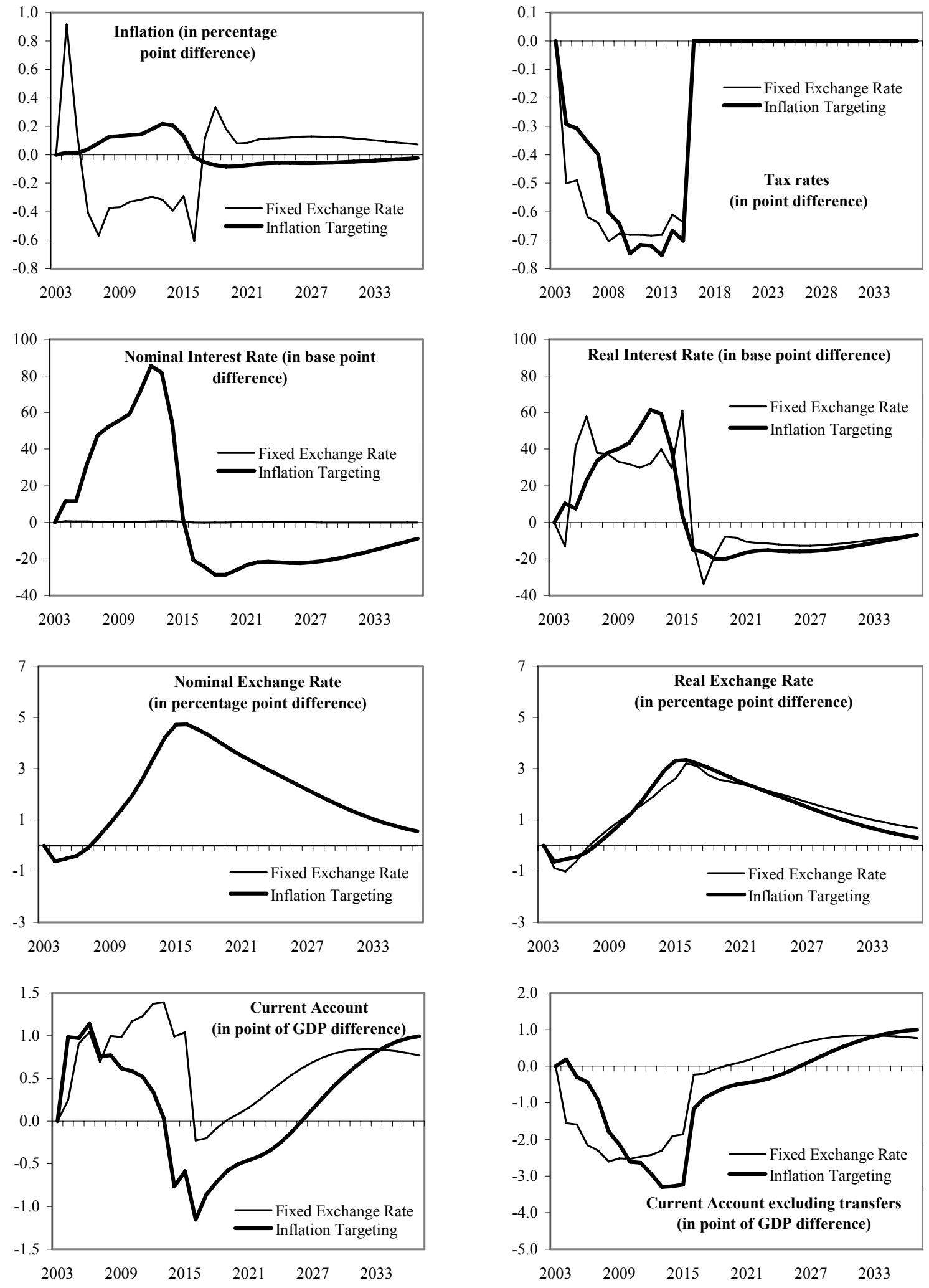

Source: IMF Staff estimates

$1 /$ This corresponds to a shock where only the private flows are transferred to households 
Appendix Figure 4b. EU Fund transfer shock, 2003-40
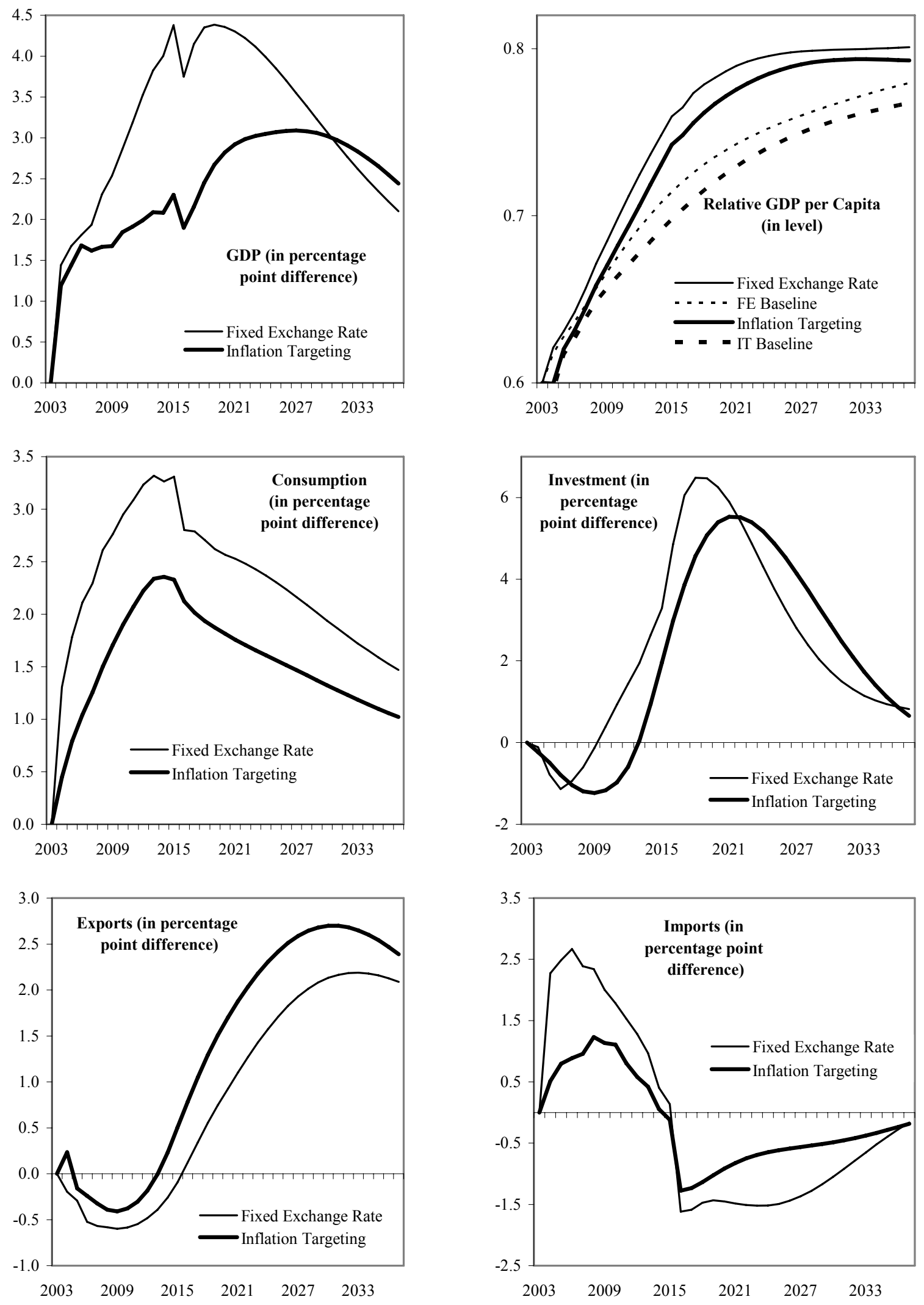

Source: IMF Staff estimates 
Appendix Figure 4c. EU Fund transfer shock, 2003-40
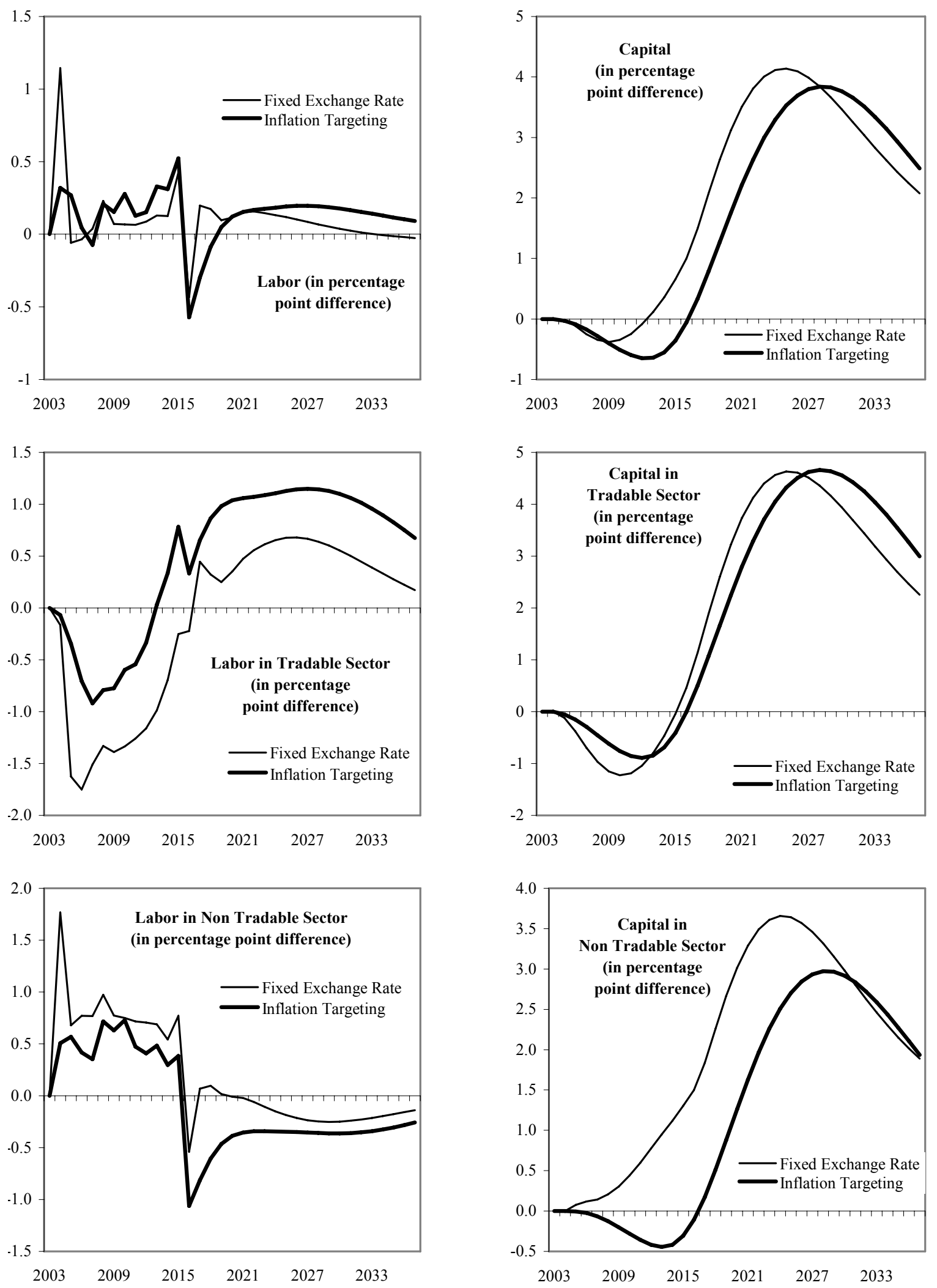

Source: IMF Staff estimates 
Appendix Figure 4d. EU Fund transfer shock, 2003-40
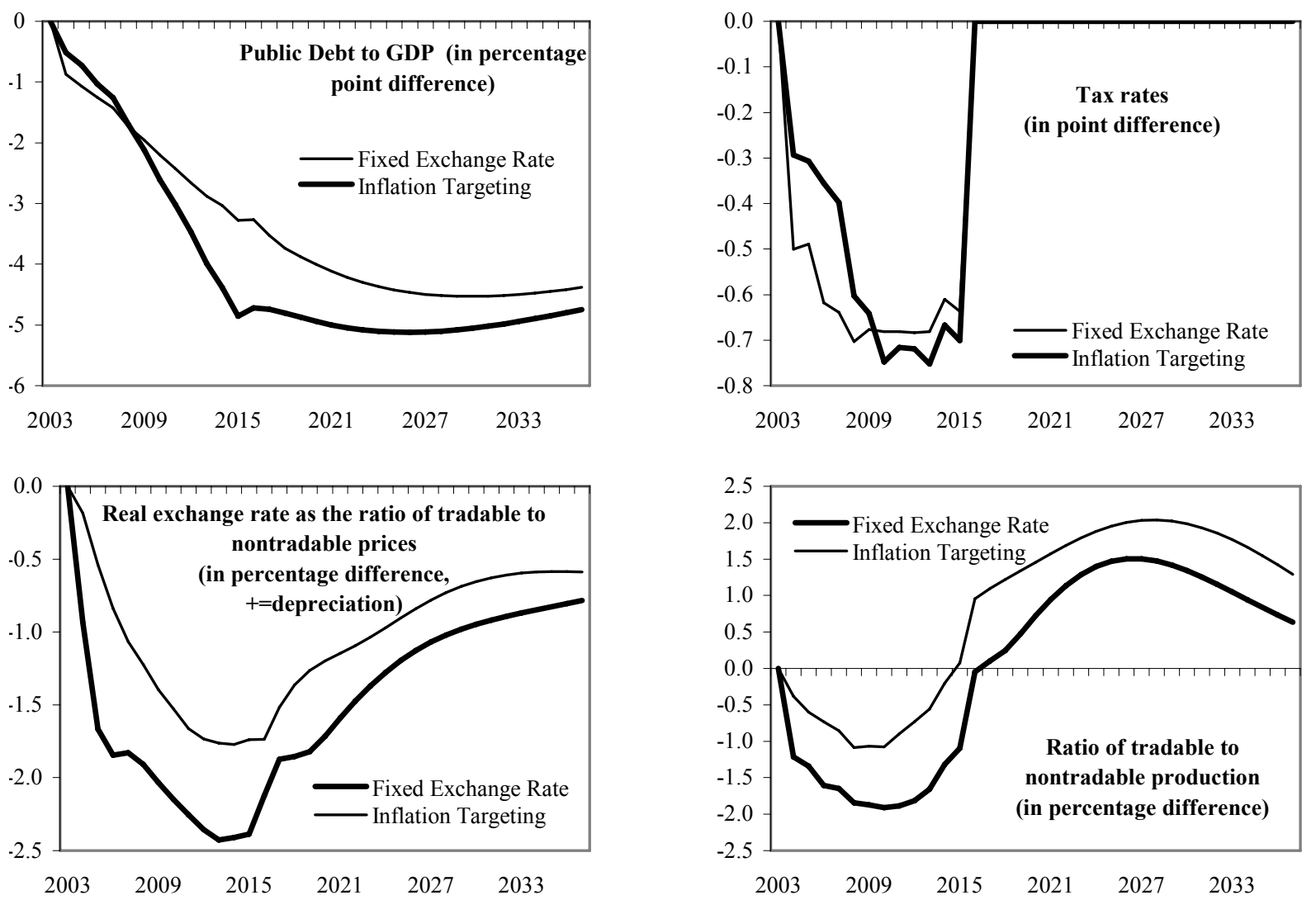

Source: IMF Staff estimates 
Appendix Figure 5a. Central Europe: EU Fund transfer shock, 2003-40
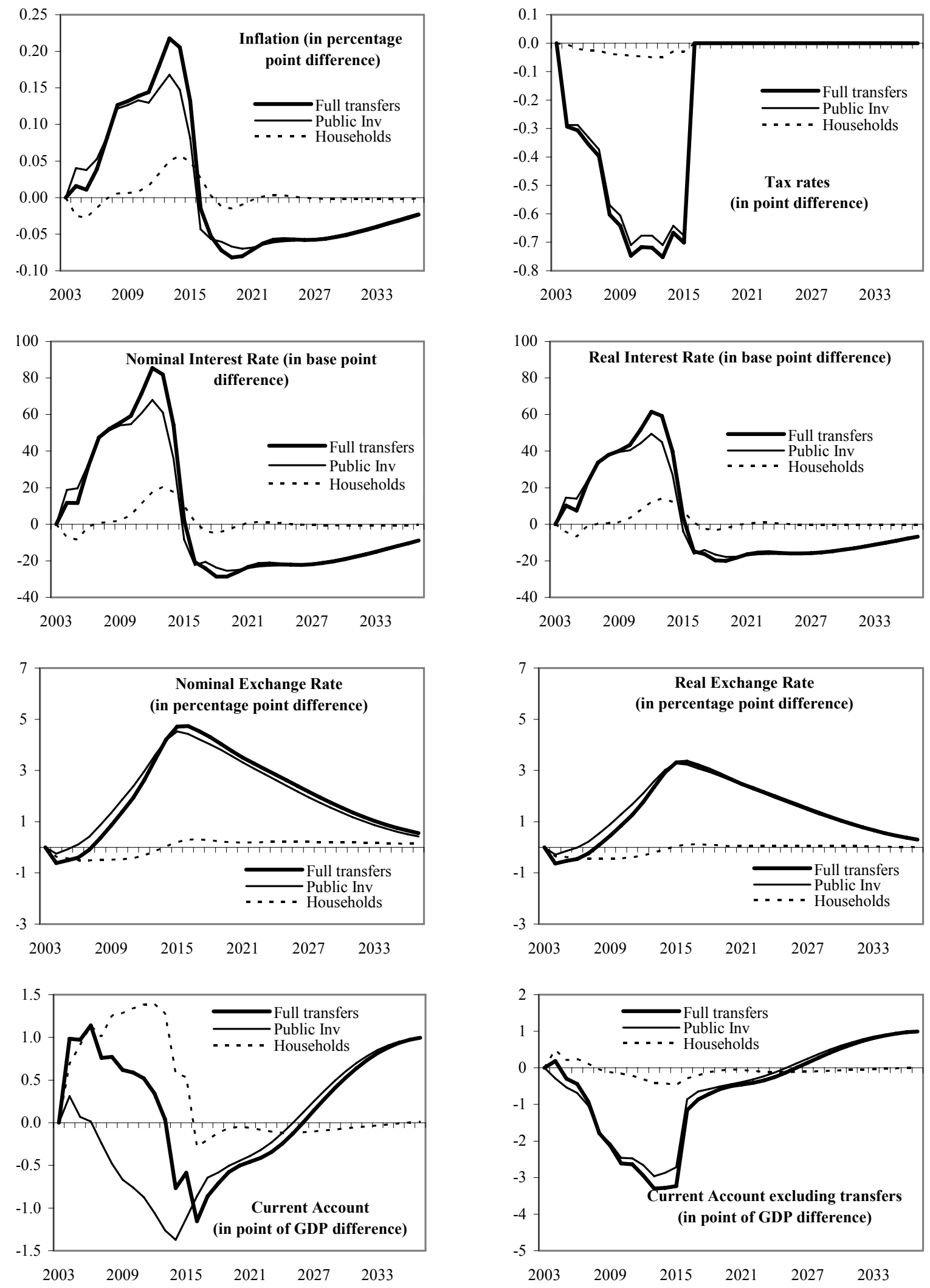

Source: IMF Staff estimates 
Appendix Figure 5b. Central Europe: EU Fund transfer shock, 2003-40
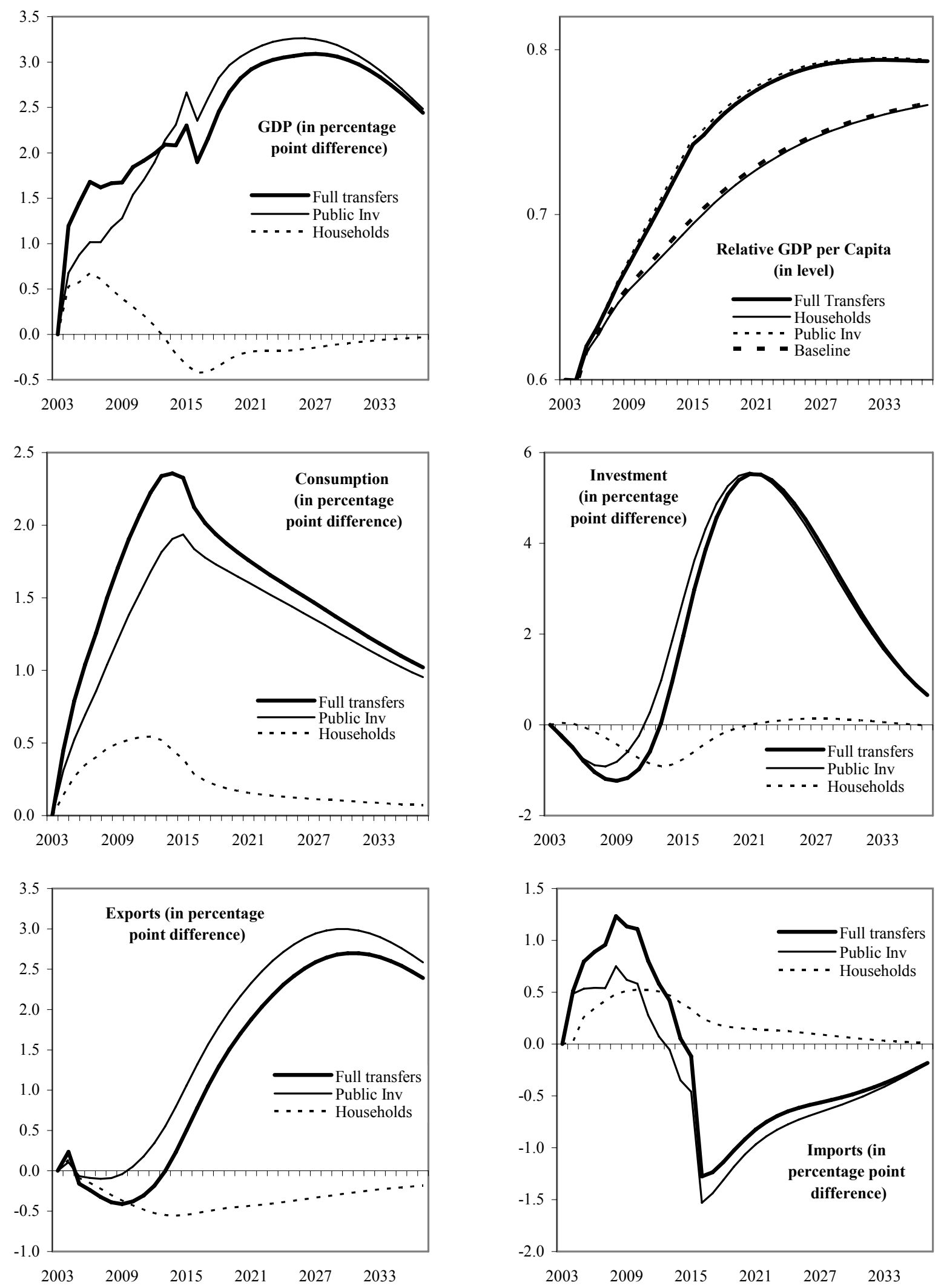

Source: IMF Staff estimates 
Appendix Figure 5c. Central Europe: EU Fund transfer shock, 2003-40
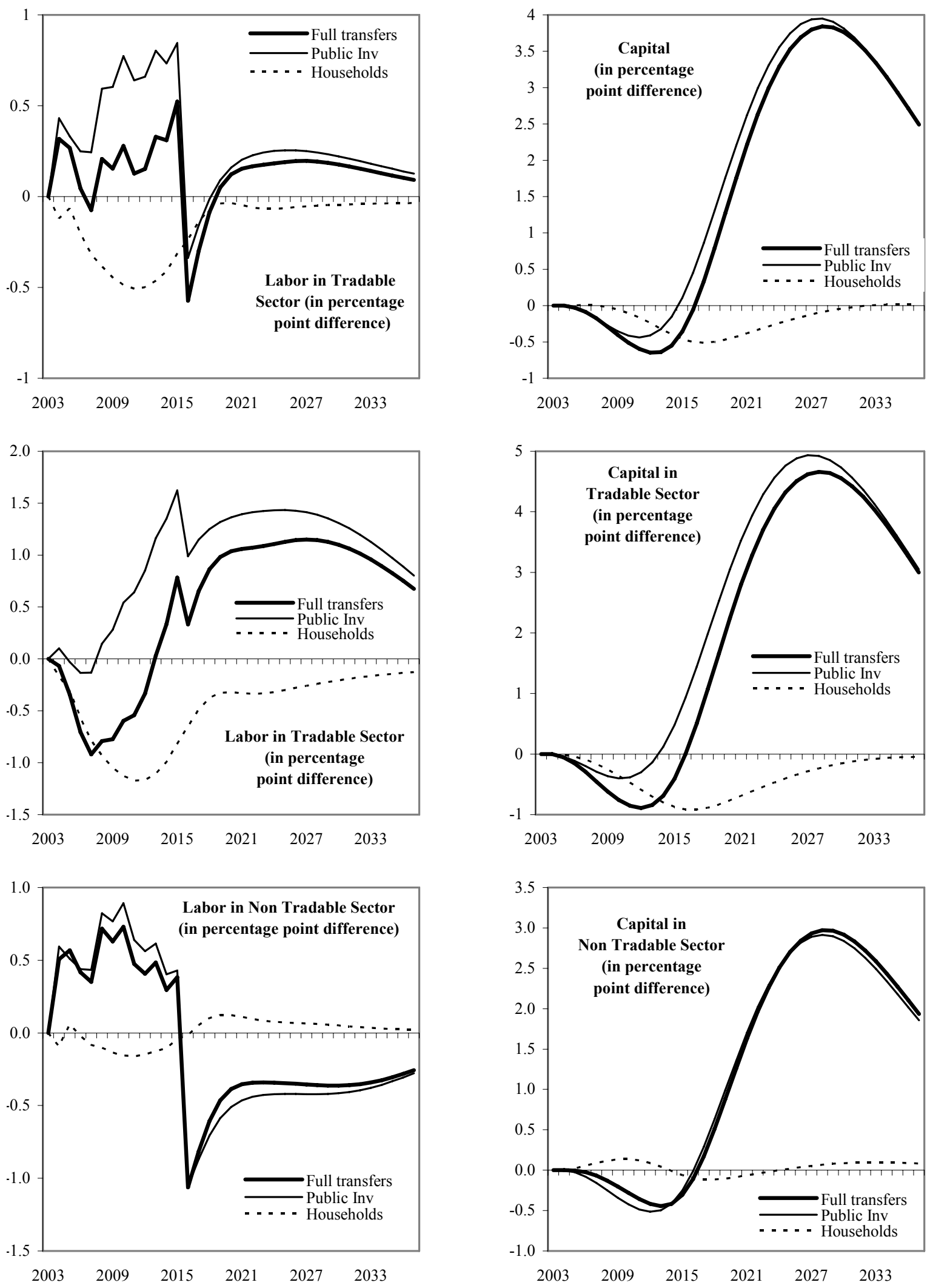

Source: IMF Staff estimates 
Appendix Figure 5d. Central Europe: EU Fund transfer shock, 2003-40
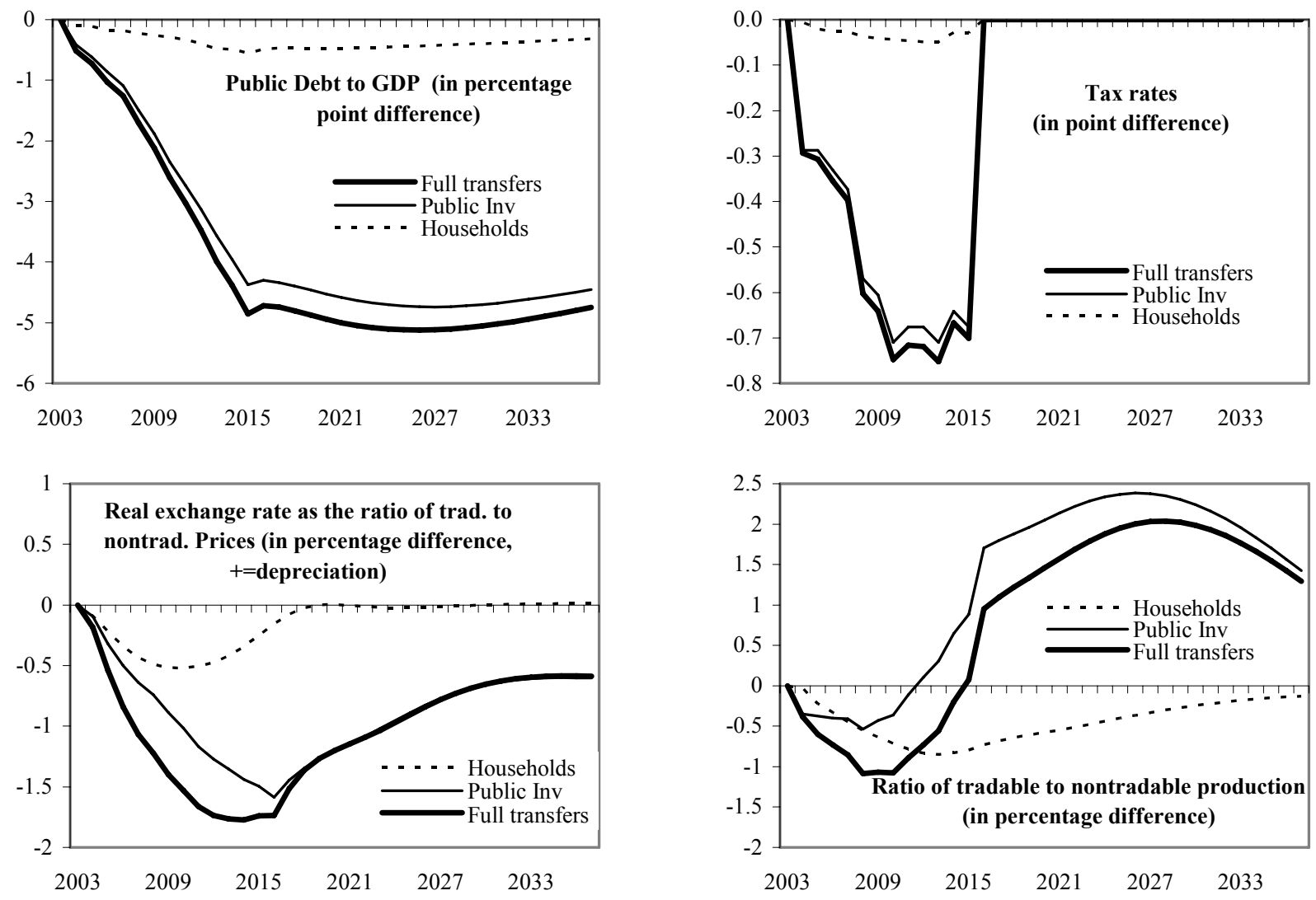

Source: IMF Staff estimates 
Appendix Figure 6a. Baltics: EU Fund transfer shock, 2003-40
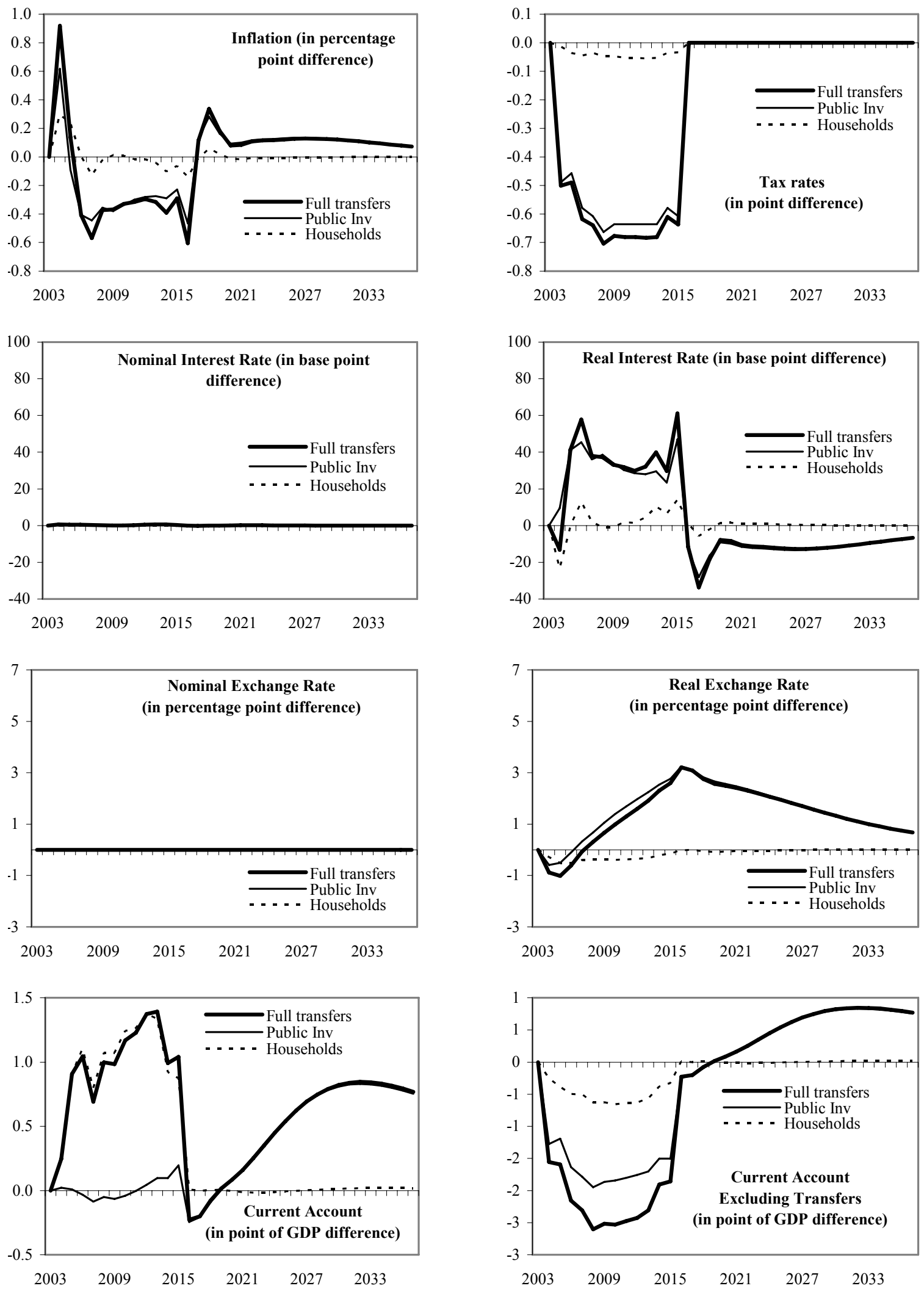

Source: IMF Staff estimates 
Appendix Figure 6b. Baltics: EU Fund transfer shock, 2003-40
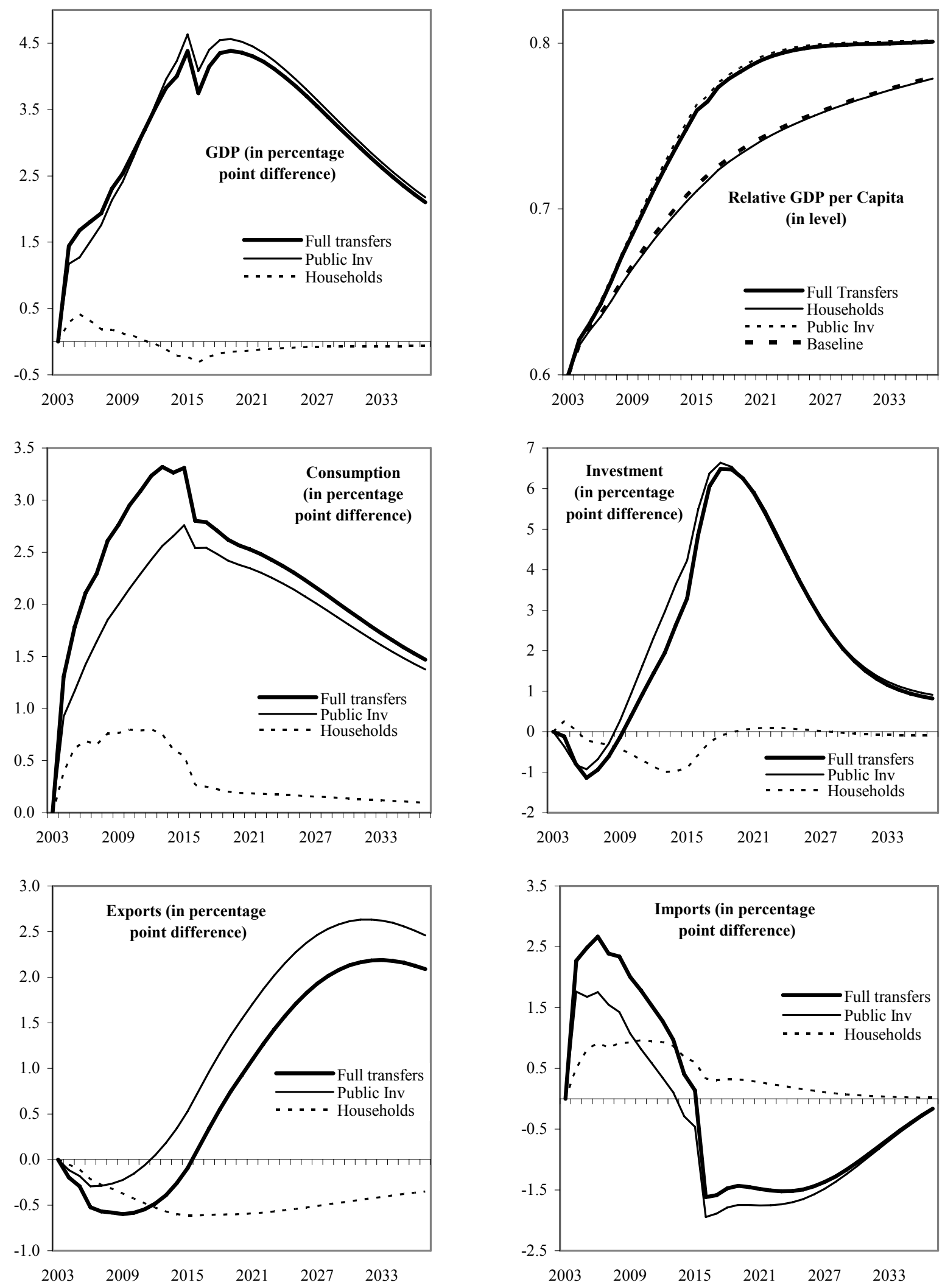

Source: IMF Staff estimates 
Appendix Figure 6c. Baltics: EU Fund transfer shock, 2003-40
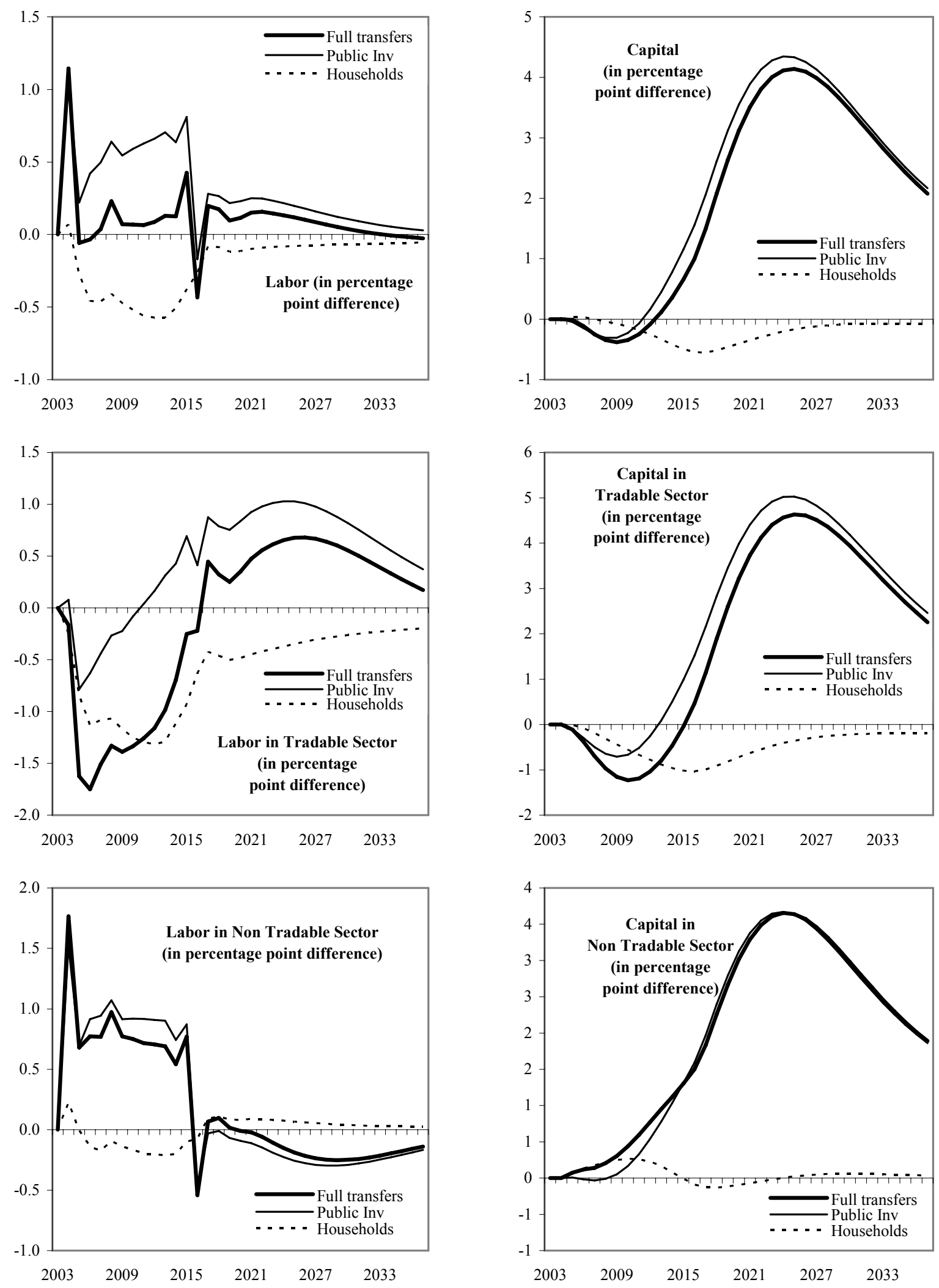

Source: IMF Staff estimates 
Appendix Figure 6d. Baltics: EU Fund transfer shock, 2003-40
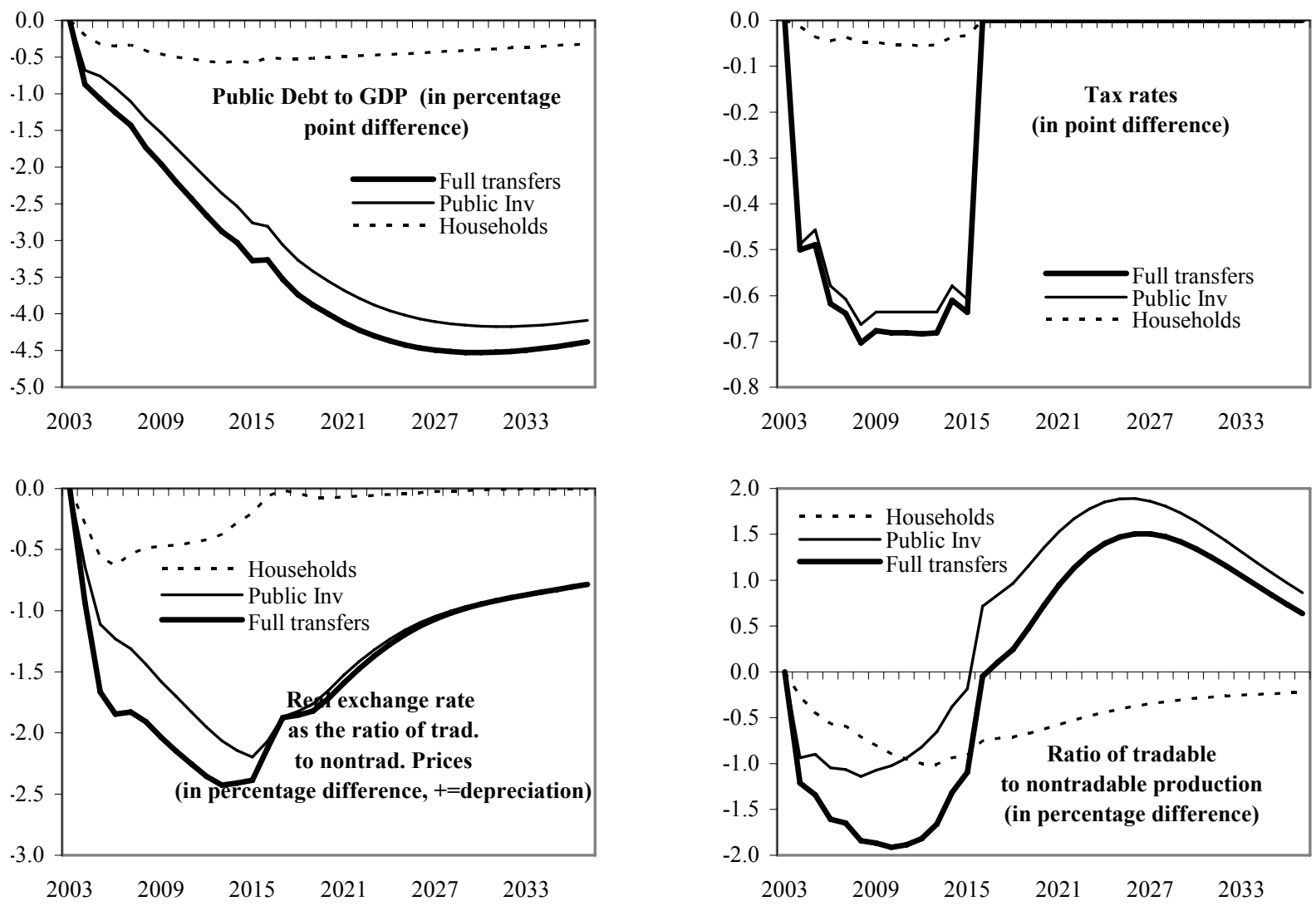

Source: IMF Staff estimates 


\section{What Can Poland Learn From Other European Union COUNTRIES In Terms OF LABOR MARKET REFORMS? ${ }^{23}$}

\section{A. Introduction}

\section{Poland's labor market has consistently underperformed, especially in the} European Union (EU) context (Figure 1). Labor utilization, defined as total persons employed as a percent of the working age population, slid by around 5 percentage points in Poland to 54 percent over the past decade, a level below any other country in the EU-15 or among Poland's regional peers (the Czech Republic, Hungary, and the Slovak Republic). In terms of constituent parts, the unemployment rate rose precipitously, peaking at 20 percent, although — aided by emigration — unemployment fell back in 2007. Also, and unusually, participation fell by over 5 percentage points over the past decade and remains depressed. Low employment rates in Poland are especially pronounced at older age groups, where withdrawal from the labor force tends to begin at 40, earlier than elsewhere and differences with other OECD countries become particularly stark after age 55 (OECD, 2006).

\section{Experience within in the EU shows that countries can-with the right policies-} vault themselves from similarly poor labor market outcomes to the top of the pack. In terms of labor market performance over the past quarter century, two countries in particular - Ireland and the Netherlands - stand apart from their peers. By the early 2000s, these two countries boasted the lowest unemployment rates in the EU, 4 percent and $4 \frac{1}{4}$ percent respectively. But it was not always that way. On the heels of a major macroeconomic crisis in the early 1980s, unemployment hovered around 13 percent in Ireland and 8 percent in the Netherlands. These countries witnessed a two-decade reduction in unemployment that outstripped any other country in the EU; indeed, the EU average barely budged. At the same time, labor utilization took off with employment growth rates in excess of any other EU country. Singling out private employment paints an even starker picture, rising in the Netherlands and Ireland by 17 and 13 percentage points respectively between the early 1980s and the early 2000s, again when the average EU employment rate remained broadly unchanged. Aside from the pure employment rate itself, participation also increased.

\section{Earlier crises often compounded longer-term structural problems in these} countries, creating the impetus for reform. ${ }^{24}$ The macroeconomic deterioration in many EU countries in the early 1980s was sparked by adverse global supply shocks and abetted by domestic policy mistakes, and this was certainly the case in Ireland and the Netherlands. In

\footnotetext{
${ }^{23}$ Prepared by Anthony Annett.

${ }^{24}$ For in-depth cases studies of the two countries, see Honohan and Walsh (2002) for Ireland, and Bakker and Halikias (1999) for the Netherlands.
} 
response, reform programs were put in place that were geared to restoring macroeconomic stability and fiscal discipline, as well as to spur growth and employment. Ireland was also in the midst of a long slow transition from low productivity agriculture to a more vibrant export sector at the time. But in the mid-1970s, a quarter of the Irish labor force still worked in agriculture. The Netherlands faced different challenges prior to reform, in the guise of severe competitiveness losses and a huge increase in the welfare state, funded by natural gas revenues.

\section{Against this backdrop, Poland might find something worthy of emulation in the} experience of countries like Ireland and the Netherlands. By the contours of the labor market, Poland in the early 2000s closely resembles these countries in earlier days, especially Ireland. In early-1980s Ireland, private sector employment occupied 46 percent of the working age population; in early $21^{\text {st }}$ century Poland, that number was 44 percent. Unemployment rates peaked in both countries during these period-17 percent in Ireland (1985) and 20 percent in Poland (2002). And the participation rate was 64 percent in Ireland at that time, the same as in Poland today. The equivalent numbers for the Netherlands are not so different. Although circumstances differ, Poland faces the same kinds of challenges today as these countries faced two decades ago, especially in the context of a prolonged transitionrelated economic restructuring. At the same time, a fifth of Poland's labor force remains in agriculture, making for a natural comparison with Ireland.

36. Ireland and Poland also share some demographic similarities. Ireland benefited uniquely from demographic factors, tapping into labor resources that stemmed from a "baby bulge" in the 1960s and 1970s, before Irish fertility declined toward the European norm. Likewise, Poland experienced a mini-baby boom in the mid-1980s, ready to enter the labor market at the dawn of the twenty-first century. Pre-Celtic Tiger Ireland had a habit of using outward emigration as a labor market safety value, a trait it also shares with modern Poland. These favorable demographics paved the way for wage moderation and macroeconomic stability in Ireland to feed through to large-scale employment growth.

37. The remainder of this paper is structured as follows: Section B provides a brief literature review pertaining to the effects of labor market institutions of employment and unemployment. It also introduces a theoretical framework for analyzing labor supply shifts. Section $\mathrm{C}$ centers around a case study of the experience in Ireland and the Netherlands, honing in on such topics as social partnership, tax wedges, benefit reform, the government wage bill, employment protection legislation (EPL), and product market regulation.

Following this, Section D offers a more analytical approach, with empirical evidence based on a sample of 14 EU countries since 1980. It largely backs up the case study conclusions, and isolates a number of core institutional factors that affected the growth in private sector employment. Section E then applies these conclusions to Poland, generating a number of policy conclusions. Section F concludes. 


\section{B. Labor Market Institutions: A Short Overview}

\section{A consensus has coalesced around the view that labor market institutions can} explain large discrepancies in employment and unemployment performance. The literature is vast. As a representative result, IMF (2003) argues that a broad array of institutional factors - including generous and long-lasting unemployment benefits, high tax wedges, restrictive employment protection legislation (EPL), and strong unions - all combine to keep unemployment high. In terms of magnitude, some argue that policies and institutions can explain slightly more half of the increase in European unemployment over the past few decades (Nickell, Nunziata, and Ochel, 2005) while others claim the number is closer to two-thirds (Bassanini and Duval, 2006). However, there is no firm consensus over the significance and importance of the different institutional variables; in these examples, the former emphasizes unemployment benefits and labor taxes above all, while the latter adds product market regulation to the mix, while playing down EPLs.

\section{The way shocks interact with institutions also matters. An oft-noted difficulty}

with the institutional explanation for labor market outcomes is that many of these institutions were firmly in place before the rise in structural unemployment. Accordingly, a major focus of the literature is the interaction between shocks and institutions. Blanchard and Wolfers (2000) argue that common macroeconomic shocks across countries have larger and more persistent effects in countries with poor labor market institutions. Blanchard (2005) favors a narrative in which governments responded to adverse shocks through strengthening labor market institutions that protected workers, which were only partially reversed from the 1980s. Duval, Elmeskov and Vogel (2007) focus on rigid labor and product markets, arguing that while these particular institutions might well dampen the initial impact of shocks, they also tend to magnify persistence. The emphasis on this strand of the literature is on levels of institutions hampering adjustment to shocks, rather than changes in institutions being directly responsible for employment performance.

\section{Much of the recent research has honed in on the flexibility in product and labor}

markets, and their interaction. There is a fair amount is disagreement on the importance of EPLs. While both Nickell, Nunziata, and Ochel (2005) and Bassanini and Duval (2006) find little effect on unemployment (possibly reflecting the fact that such restrictions inhibit both hiring and layoffs), Garibaldi and Mauro (2002) hold that employment growth is associated primarily with low dismissal costs and low taxes. Adding more nuance, OECD (2004) finds that EPLs reduce the employment rate among youth and women, but not prime-age men. And as noted above, some of more recent results lay the blame for high unemployment on rigid product markets. Others highlight non-linear effects. Nicoletti and Scarpetta (2005) argue that product market regulation affects employment growth, with a stronger effect in the presence of rigid labor market conditions, reflecting insider's bargaining power. Berger and Danninger (2005) also suggest that the interaction between labor and product market rigidity affects employment growth, so that liberalizing one market is more beneficial when the other 
is more competitive. Estevao (2005) shows that shifts in labor supply translates into greater reductions in unemployment in the presence of liberal product markets, when incumbent firms do not appropriate rents.

\section{Unions can have a positive effect, especially in the context of centralized and} coordinated wage bargaining. A while back, Calmfors and Driffill (1988) argued that both centralized and decentralized wage bargaining facilitated low unemployment, with the intermediate case leading to inferior outcomes. The supposition was that, under centralized bargaining, unions take account of the economy-wide implications of wage-setting. Others have argued that what matters most is not centralization, but coordination, in the sense that counterpart employer's organizations bargain with unions (Soskice, 1990). This effect is a common feature of the literature. Daveri and Tabellini (2000) contend that labor tax rates feed through to gross wages at intermediate levels of wage bargaining, but not in decentralized or centralized systems. Similarly, Alesina and Perotti (1997) discover a relationship between labor taxes and relative unit labor costs in an intermediate bargaining environment, but not otherwise; the intuition given is that with economy wide bargaining, unions internalize the link between taxes and benefits. Nickell, Nunziata, and Ochel (2005) find that coordination mitigates the effects of union density and tax rates, while Bassanini and Duval (2006) point to clear positive effects from centralization and/or coordination. Some go even further and argue that the "positive" effect of coordination is both sizeable in magnitude and one of the few robust results in the whole literature (Baker and others, 2002).

\section{When pondering the effects of institutions on labor market outcomes, a simple} wage bargaining model provides an effective analytical foundation. In a world where employers and workers bargain over wages, the "wage curve" (analogous to a labor supply curve) measures the positive relationship between wages and the employment rate, given that the probability of being unemployed dampens wage demands. ${ }^{25}$ In such a framework, negotiated wages are set as a mark-up over the alternative income of workers, where the mark-up depends on the workers' bargaining power. "Wage moderation" can be therefore be interpreted as a structural changes in unions' approach to wage bargaining, or a downward shift in the wage curve. The wage moderation variable can be calculated as the change in the productivity and cyclically-adjusted real hourly compensation rate. ${ }^{26}$

\footnotetext{
${ }^{25}$ For details, see Decressin and others (2001) and Estevao (2005).

${ }^{26}$ More technically, the hourly compensation rate in the business sector is deflated by the private consumption deflator and an index of labor-augmenting technical progress. But since changes in wages may simply reflect cyclical changes in unemployment, or a movement along the wage curve without any change in the workers' underlying stance, the growth in wages is also adjusted for the change in the unemployment rate, based on an assumed elasticity of wage costs to unemployment of 0.1 , a standard assumption in the wage curve literature. Again, see Decressin and others (2001) and Estevao (2005) for more details.
} 
43. Given this framework, a number of institutional factors can shift the wage curve downwards - more supply at a given wage or a lower wage at a given supply. The most prominent effects include:

- $\quad$ Preferences of unions and workers. Workers shift their preferences away from wages toward employment, as might happen if the wage bargaining system became more centralized or coordinated.

- Lower tax wedges. A reduction in tax wedges (from labor taxes or social security contributions) leads workers to accept lower wages at given employment rates, since net wages have increased.

- Lower alternate income transfers. Unemployment benefits affect the reservation wage of workers directly. It is not just the level of unemployment benefit that matters here, but also duration and ease of access. At the same time, other transfers that act as alternative employment income would have the same effect, including disability payments and early retirement pensions.

- Lower government wages. Given that government employment is an alternative to private sector employment, a reduction in the government wage bill also reduces reservation income (see Ardagna, 2004). Both wage and employment matter: the government wage rate exerts a direct influence on bargaining stance, and a decrease in government employment increases the probability of being unemployed. There could also be a more subtle effect as a powerful public sector (or a strong public sector union) pushes up tax rates to pay for the increasing wage bill, which in turn increases private sector wages. ${ }^{27}$

\section{The Dutch and Irish Experience}

44. Both Ireland and the Netherlands are have experienced employment booms that are testament to substantial wage moderation since the mid-1980s. Indeed, by the late 1990s, changes in wage setting conditions leading to wage curve shifts were most significant in these two countries, with productivity and cyclically-adjusted real hourly wages (as defined in the previous section) falling by nearly 50 percent and 20 percent respectively from the 1980s, the largest declines among EU countries (see Figure 2). While a number of other countries (such as Finland and Portugal) also engaged in wage moderation, the EU average barely changed across this time horizon. It is no coincidence that Ireland and the Netherlands enjoyed the strongest labor market performance over this period.

\footnotetext{
${ }^{27}$ Annett (1998) shows that "public sector union density" is associated with increasing relative unit labor costs.
} 
45. As an overarching framework, wage moderation in Ireland and the Netherlands was facilitated by coordinated agreements between social partners. At the core of the Dutch and Irish programs was a strategy to mitigate the effects of lower nominal wage growth with labor tax cuts. The seminal Wassenaar agreement in the Netherlands was signed in 1982 between the leading labor federation and the employer's federation, trading wage restraint for working hour reductions, alongside government commitments to reduce labor taxes and social security contributions. Unions also ceased their opposition to part-time jobs. Ireland adapted a similar approach in 1987, bringing together an array of vested interests to secure low nominal wage growth, tax cuts, and fiscal discipline. Although the Irish wage agreements applied only explicitly to the unionized sector, the agreements acted as a more general benchmark for wage expectations (see Box 1 for details). Given its success, this strategy has continued unabated in both countries. The Wassenaar agreement was updated in 1989, 1993, and 1997, and a total of seven medium-term agreements were negotiated in Ireland.

\section{This exercise in social partnership is compatible with different forms of} underlying institutions and cultures. Interestingly, the two countries began the experiment with vastly different backgrounds. The Netherlands enjoyed a long history of corporatism and consensus-driven policymaking, especially in the domain of wage bargaining (Hartog, 1999). Moreover, certain aspects of the legal institutional framework fostered the consensusbased approach. Laws from the interwar period made any agreement with a union binding on all the workers in the firm, and allowed the government to extend a collective agreement that covered a large majority of the industry to the entire industry. Ireland, on the other hand, had no such corporatist history, but this kind of inclusive social partnership was not alien to it either, being well-grounded in Catholic social teaching. ${ }^{28}$ More urgently, the gravity of the macroeconomic approach argued in favor of aligned interests. Waning union membership also gave union leaders a stake in the process, and indeed, the position of unions was strengthened with the shift to centralized wage bargaining. ${ }^{29}$ The feeling of aligned interests persisted during the drawn-out process of deepening EU integration and eventual euro adoption.

\section{In line with the reform programs, tax wedges on labor income declined steadily} in both Ireland and the Netherlands (Figure 3). Between the early 1980s and the early

\footnotetext{
${ }^{28}$ For example, Quadragesimo Anno (1931) argues in favor of an organic conception of social unity, where society is organized as a collection of groups that work together to achieve the common good. Accordingly, corporations, labor unions and government would bargain over wages, hours worked, and working conditions.

${ }^{29}$ Membership in unions declined from around 48 percent of the labor force in 1980 to around 40 percent a decade later (Honohan and Walsh, 2002).
} 
2000s, the tax wedge ${ }^{30}$ declined by 10 percentage points in the Netherlands, and almost 14 percentage points in Ireland, while it actually increased marginally in the average of the other EU countries. In both countries, the decline in the tax wedge represented a clear government commitment to compensate for wage moderation by cutting taxes on labor income. In Ireland, the top income tax fell from $681 \frac{1}{2}$ percent in the mid-1980s to 42 percent by the end of the century. At the same time, income tax thresholds were raised in real terms, removing many of the low paid from the tax net altogether. In the Netherlands, social security contributions were cut dramatically (by 58 percent) for low-income workers, and if these workers came from long-term unemployment, they were exempted from contributions during the first four years of employment (Bakker and Halikias, 1999).

\section{Benefit reform was a key ingredient in the reform agenda, especially in the}

Netherlands. The authorities acted on all fronts: reducing generosity, shortening duration and tightening eligibility requirements. In 1986, the replacement rate for unemployment, sickness, and disability benefits was reduced from 80 percent to 70 percent of the last earned wage and the disabled unemployed no longer received full benefits. The minimum wage fell, as did social benefits linked to it. Simultaneously, the duration of unemployment benefits was cut from $2 \frac{1}{2}$ years to six months for workers under 23 , and less severely for other age groups (except for those over 58 who received six years of eligibility). After 1993, the period under which disability benefit recipients could receive full benefits was similarly restricted. Eligibility became progressively tighter, so that by 1995, the unemployed needed to stand ready to accept a broader range of jobs or enter training, and were required to accept any job offer after 18 months of unemployment. ${ }^{31}$ Applicants for disability were gauged on whether they could perform any job, regardless of training or employment history, and those under 50 were reexamined. In Ireland, the welfare state was not very generous to start with, and reforms in this area were less important. However, benefits failed to keep pace with after-tax income, and replacement rates declined. Also, criteria were toughened from 1998, as all those unemployed for longer than six months were required to attend interviews in an attempt to improve matching or identify training needs (Walsh, 2003).

\footnotetext{
${ }^{30}$ The tax wedge is defined as employee's and employers' social security contributions and personal income tax less transfer payments as percent of gross labor costs, averaged between single and married workers.

${ }^{31}$ By 1998, the sanction rate - defined as sanctions during benefit periods as a percentage of the average stock of benefit claims - was 36 percent, the highest in the OECD (Nickell and van Ours, 2000).
} 


\section{Box II.1: Centralized/Coordinated Wage Bargaining Agreements in Ireland}

The social partners negotiated seven medium-term agreements between 1987-08:

Programme for National Recovery (1988-1990): Unions agreed to curtail annual wage increases to 3 percent up to a certain threshold, and 2 percent thereafter, in return for government commitments to income tax reform and cutting public spending to secure fiscal consolidation.

Programme for Economic and Social Progress (1991-93): The agreement established wage increases of 4 percent, 3 percent, and $3 \frac{3}{4}$ percent in each year of the program. An additional 3 percent was allowed for local bargaining based on competitiveness considerations.

Programme for Competitiveness and Work (1994-96): Private sector workers gained 2 percent in the first year, $2^{1 / 2}$ percent in the second year, $2^{1 / 2}$ percent in the first half of the third year, and 1 percent in the latter half of the third year. Public sector wage increases were also included in the negotiation.

Partnership 2000 (1997-99): Pay increases were set at 21/2 percent in the first year, 21/4 percent in the second, $1 \frac{1}{2}$ over the next nine months, and 1 percent in the last six months. Local-level augmentations were restricted to 2 percent. The government agreed to tax cuts designed to increase after-tax income by 5 percent. Both the number of issues and the number of social partners increased during this round-new issues included social inclusion, promoting enterprise, and public sector modernization.

Programme for Prosperity and Fairness (2000-02): Pay increases totaled 51/2 percent in the first two years, and 4 percent in the last nine months of the program. The public sector was placed under these pay ceilings, but the last increase was contingent on achieving various performance indicators. Partners also agreed to set up a public sector benchmarking exercise. Again, there was a commitment to labor tax cuts to ensure large increases in net pay.

Sustaining Progress (2003-05): In the first period, pay rises equaled 3 percent for the first nine months, 2 percent in the next six months, and 2 percent for the next three months. In the second period, negotiated in 2004, workers received $1 \frac{1}{2}$ percent in both the first and second six-month period, and $2 \frac{1}{2}$ percent at the end. There was agreement that benchmarking would become a regular feature of the bargaining rounds. The number of initiatives and partners continued to mount.

Towards 2016: (2006-08): Within the framework of a broader agreement on a 10-year economic social development strategy, pay increases were set out for the first 27 months as follows:

3 percent for the first six months, 2 percent for the next nine months, and $2 \frac{1}{2}$ percent in each of the final six-month periods.

Source: Hunt (2004) and Irish government websites. 
49. The Netherlands also moved toward the "privatization" of welfare benefits, as risks were shifted to employers and private insurance schemes. The disability scheme created acute problems, and incapacity-related benefits ate up 6 percent of GDP by 1990. The old system created some poor incentives, as all parties had their own motives for preferring the disability to the unemployment benefit channel (Barrell and Genre, 1999). Workers could gain higher compensation from disability benefits than unemployment benefits, while employers could avoid the cost of redundancies. And of course, politicians could reap the gains from artificially low unemployment numbers. From 1994, employers were made responsible for the first six weeks of sick leave, and this was extended to a full year in 1996, after which the person moved to disability status. From 1998, disability premiums were fully paid by employers, and differentiated by enterprise. Moreover, private companies could provide insurance for the first five years. From 1997, management of the social security system - until then in the hands of the unions and employers organizationswas contracted out to social security agencies, which were allowed to compete with each other and with private companies (see Bakker and Halikias, 1999). Incapacity-related benefits fell to 4 percent of GDP by 2003, a large decline but still on the high side by EU standards.

\section{Ireland and the Netherlands also stand out in terms of reducing the size of the} government wage bill. Again, while the ratio of government wages to GDP barely budged in the EU, it declined markedly in Ireland and the Netherlands $\left(3 \frac{1}{2}\right.$ and $3 \frac{3}{4}$ percentage points respectively over a twenty-year period); this was driven especially by declining relative government employment. In Ireland, the stabilization program included a freeze on the public sector wage bill. In two years alone, public employment fell by more than 10 percent. The Netherlands embarked on a similar path, as the government wage bill was held down both by containing salaries and employment. Especially during the initial phase of the negotiated agreements, the government's responsibility lay in the domain of restoring fiscal discipline, and holding back growth in the government wage bill was a core component of this strategy.

\section{Indeed, in these countries, fiscal adjustment and reforms that address labor}

supply went hand-in-hand. Both countries recorded sustained fiscal adjustment, even though the tax burden was falling at the same time - this is consistent with evidence that adjustment episodes that tend to be successful and expansionary are those that rely on cutting government wages and transfers (Alesina and Ardagna, 1998). In the context of the wage bargaining framework discussed earlier, all factors work together to support wage moderation. Reducing government wages and transfers, as well as cutting labor taxes, prompts unions to accept lower wages, which in turn leads to higher profitability, employment, investment, and growth (Ardagna, 2004; Alesina and others, 2002). Granting tax cuts also neuters potential opposition to labor supply reforms. 


\section{Ireland and the Netherlands also tend to have relatively liberal labor and product markets (Figure 4):}

- Neither country has very restrictive employment protection, looking at indices of EPLs. ${ }^{32}$ Labor markets in Ireland are especially liberal, ranking just behind the United Kingdom within the EU. The Netherlands' relative position improves dramatically when looking at restrictions on temporary employment, coming in just after Ireland and the UK, as it liberalized in this area over the reform period. Dutch reforms focused on streamlining laying off rules and relaxing hiring procedures, working time rules, overtime legislation, and regulations relating to temporary work agencies.

- A similar story can be told with OECD indices of product market regulation. ${ }^{33}$ Again, Ireland appears the most liberal country after the United Kingdom, and while the Netherlands appears more middling, it was in the bottom cluster in 1998, the last time the survey was conducted before 2003. And while this economy-wide index has only two observations, another OECD index provides information on seven nonmanufacturing sectors - airlines, telecoms, electricity, gas, post, rail, and road freight - between 1975-2003 (Conway and Nicoletti, 2006). According to these data, the Netherlands has liberalized more than any other EU country during this period, ending up second only to the United Kingdom. Ireland focused its reform efforts on administrative simplification and openness to trade and foreign direct investment (Nicoletti and Scarpetta, 2005).

\section{Empirical Analysis}

\section{To complement this brief descriptive narrative, this section presents an} econometric analysis. Specifically, it uses of a panel of 14 EU countries (excluding Luxembourg) to investigate the policy determinants of wage curve shifts, and how wage moderation feeds through to private sector employment.

\section{In the first instance, the results show that the lessons from Ireland and Netherlands can be generalized as regards the determinants of wage curve shifts}

\footnotetext{
32 The OECD index relates to the strictness of EPLs considering such factors as difficulty of dismissal, notice and severance pay provisions, specific requirements for collective dismissals, and regulation of temporary employment. See OECD (2004).

${ }^{33}$ The index is based on a computed questionnaire of general and sectoral regulatory policies in each country. Categories include state controls, public ownership and involvement in business operations, barriers to entrepreneurship (encompassing regulatory and administrative opacity, administrative burdens and start-ups, and barriers to competition) and barriers to trade and investment. See Conway, Janod, and Nicoletti, (2005).
} 
(Table 1). The estimated equation relates annual changes in wage curve shifts as defined earlier - cyclically- and productivity- adjusted real hourly wages in the private sector - to changes in the key policy variables in question, including the tax wedge on labor income, some measure of benefits, and the government wage bill. ${ }^{34} \mathrm{~A}$ panel model is estimated for 14 countries (the EU-15 excluding Luxembourg) between 1980-2006, with and without fixed effects (equations 1 and 2 of Table 1). Year dummies capture common excluded variables. To capture dynamics, the estimated equation includes a single lag on the dependent variable. ${ }^{35}$ Standard errors are asymptotically robust to both heteroskedasticity and serial correlation. Taking the variables in turn:

- The coefficient on the change in the tax wedge - calculated as employee's and employers' social security contributions and personal income tax less transfer payments as percent of gross labor costs, averaged between single and married workers - is positive and significant, in accord with theory. However, including this variable alongside a measure of benefits risks an element of multicollinearity.

- $\quad$ The benefits story is somewhat more nuanced. It turns out that changes in replacement rates (either for the first year alone, and or for an average of five years) does not seem to affect wages. One explanation may be that some countries rely on high replacement rates in the context of a flexible economy, where the protection is on jobs not workers, and where there are stern activation requirements. Benefits duration is also insignificant in this estimated equation. A key problem with the relying on the replacement rate is that it focuses principally on unemployment benefits, rather than on those programs that facilitate exit from the labor force itself, such as incapacity-related and early retirement benefits. A broader approach might prove more fruitful when the focus is on total (private sector) employment.

Accordingly, the next step was to include a measure of expenditure that might affect labor supply adversely - unemployment benefits, incapacity related benefits, and early retirement benefits. Of these three, only changes in incapacity-related benefits exerted the theoretically-expected effect on the wage curve, with a positive and statistically significant coefficient. The absence of any impact from unemployment

\footnotetext{
${ }^{34}$ Remember, the growth in wages is also adjusted for the change in the unemployment rate, so that this variable can capture a shift of (rather than a movement along) the wage curve.

${ }^{35}$ A well-known problem with dynamic panel models is that the lagged dependent variable will be correlated with the individual effects in the error term, rendering OLS estimation inconsistent. Using fixed effects will not remove this inconsistency, unless the number of time periods is large, typically greater than 15 or 20 (see Bond, 2002). Indeed, Judson and Owen (1999) argue that when the time series is long enough relative to the crosssection dimension, the bias inherent in dynamic panel estimation is not large enough to make alternative estimators more desirable. Still, the GMM estimation procedure-which controls for the econometric problems of such a specification - is employed as a robustness check on the results.
} 
benefits probably reflects its highly cyclical nature, while early retirement benefits are important in only a handful of countries.

- $\quad$ The effect of the government wage bill is positive, as predicted by theory, indicated by a statistically significant relationship between changes in wage government consumption and wage curve shifts. Interestingly, the magnitude of the effect is greater for government wages than for other variables, consistent with previous results in the literature; Alesina and others (2002) for example, find a large effect of government wages on profits and business investment, larger than the effect of either labor or business taxation, and they attribute this result to the labor market channel. Breaking the government wage bill into its constituent parts, equation 3 of Table 1 shows that both the employment (government employment as a percent of total employment) and wage (real wage rate in the government sector) channels are in effect, although the former is statistically larger.

- $\quad$ Finally, equation 4 of Table 6 investigates whether changes in the underlying negotiating stance workers effects wage outcomes, especially in light of the Dutch and Irish experiences. The variable in question is an average of the OECD's centralization and coordination indices, ${ }^{36}$ The change in this index yields a negative and statistically significant coefficient, signifying a positive effect of centralizing and coordinating wage bargaining. This result comes with some caution, however. First, it is difficult to isolate the effects of changing institutions per se from changes in other variables (such as tax wedges, benefits, and government wages) that were key ingredients in the negotiated agreements in Ireland and the Netherlands. Second, the indices are highly subjective, calling for ad hoc judgment in many instances. Indeed, there are many indices in the literature purporting to measure coordination and centralization that are only weakly correlated. ${ }^{37}$ In that regard, the OECD indices are among the newer and more detailed. Third, these variables often have little time

\footnotetext{
${ }^{36}$ Both indices are scaled from 1 to 5 . For centralization, "1" means predominantly company and plant-level bargaining, " 3 " signifies negotiation at the industry level, and " 5 " refers to situations where central-level agreements are key (" 2 " and " 4 " are intermediate cases). The coordination index is more complex. "1" refers to a situation comprised of fragmented company/ plant bargaining, with little or no coordination by upper-level associations. " 3 " denotes industry-level bargaining with irregular pattern-setting and moderate coordination among the major bargaining actors. " 4 " features such institutional features as coordinated bargaining by peak confederations, including government-sponsored negotiations; informal coordination of industry and firm-level bargaining by multiple peak associations; regular pattern-setting coupled with high union concentration and/or bargaining coordination by large firms; and government wage arbitration. Finally, "5" refers to either informal coordination of industry-level bargaining by an encompassing union confederation or coordinated bargaining by peak confederations of government imposition of a wage schedule/ freeze, with a peace obligation.
}

${ }^{37}$ See, for example, the indices of Stephen Nickell (from the Labor Market Institutions Database) and Lane Kenworthy (http://www.u.arizona.edu/ lkenwor/data.html). 
variation, presenting problems for fixed effects estimation in particular. Fourth, the absence of a hump-shaped relationship is possibly due to the fact that only one country in the sample (the United Kingdom) is listed as fully decentralized and uncoordinated. Despite these caveats, moving to a more centralized and coordinated arrangement seems to foster wage curve shifts, consistent with changes in underlying stance.

\section{The basic equation is also estimated using GMM techniques. GMM provides a} framework for coping with dynamic panel bias and dealing with more general issues of endogeneity. In the current analysis, however, the number of time periods should be sufficient to neutralize the dynamic panel bias. Indeed, the coefficient on the upwardlybiased OLS coefficient on the lagged dependent variable (0.32) is quite close to that of the downwardly-biased fixed effects coefficient (0.28), arguing against problems in this area. Still, GMM controls for endogeneity and offers a useful robustness check on the earlier results. First Difference-GMM (or Arellano-Bond) takes first differences to eliminate the individual effects and uses lagged levels as instruments, while System GMM estimates equations in levels (using lagged first differences as instruments) as well as in first differences. Results are shown in columns 5 and 6 in Table $1 .{ }^{38}$ All variables are treated as endogenous, although this assumption is not essential. ${ }^{39}$ Relative to the fixed effects, the previous results are all confirmed, although with somewhat lower coefficients on the key variables. Specification tests point to absence of problems, especially with the System GMM estimation. ${ }^{40}$ Also, the coefficient on the lagged dependent variable in this equation lies between the OLS and fixed effects estimated coefficients, the expected domain of a consistent estimator.

\section{The next step is to examine the transmission mechanism from wage curve shifts} to actual private sector employment generation (Table 2). A core result is that this effect depends on the underlying flexibility of labor and product markets. Using the same definition of wage curve shifts, Estevao (2005) notes that the effect of wage moderation on

\footnotetext{
${ }^{38}$ To ward off problems of overfitting, a serious issue in small samples, the number of instruments was limited from the second through the fifth lags in the first differenced equations, and the lagged first difference of the first lag as instruments in the levels equation.
}

\footnotetext{
${ }^{39}$ Endogeneity might be an issue with some variables. For example, wage moderation might lead unions to seek centralized and coordinated agreements to secure power, or lead to lower public sector wages in tandem.
}

\footnotetext{
${ }^{40}$ With First Difference GMM, the Sargan-Hansen test of over-identifying restrictions is rejected, casting doubt on the validity of the instruments in this equation. But the validity of the instruments underpinning System GMM is accepted. The Difference Sargan also accepts the validity of the additional instruments in the levels equation. The modified residuals should have negative first order serial correlation and no second order serial correlation - consistent with no serial correlation in the original residuals. And indeed, there is scant evidence of autocorrelation in the current model.
} 
unemployment and output growth is more muted in an environment of weaker competition and greater barriers to entry as incumbent firms are able to appropriate larger rents. Similarly, Annett (2007) argued that employment protection legislation also matters, as shifting labor between sectors in response to wage curve shifts becomes more cumbersome in an environment of rigid labor markets. Presently, an equation is estimated whereby the change in the ratio of private sector employment to working-age population is related to wage curve shifts, product market regulation ${ }^{41}$, labor market regulation, and the interaction between wage curve shifts and these two regulatory indices. Once again, the equations are estimated using pooled OLS, fixed effects, First Difference GMM, and System GMM. And again, year dummies are included to capture common excluded variables. This time, three lags of the dependent variable are included in the equation to clean the residuals of autocorrelation, in line with Estevao (2005). The time series is slightly shorter here, as EPLs are only measured from 1985. The same restrictions on the instruments in the GMM estimation are in place.

\section{The results show that the effects of wage moderation on employment are} conditional on the levels of product and labor market regulation. Unsurprisingly, the coefficient on wage curve shifts is negative and significant in all specifications. In themselves, the coefficients on the indices of product and labor market regulation are statistically insignificant. However, the interactive coefficients are both positive and statistically significant, implying that the negative relationship between wage moderation and private sector employment is smaller in countries with heavily regulated product and labor markets. Confirming earlier results, this suggests that the benefits of wage moderation are greater in countries with more liberal product and labor markets. In the GMM estimation, the variables are treated as endogenous, and adding the variables from the equation in Table 1 as instruments (changes in the tax wedge, incapacity-related benefits, and the government wage bill) does not change the results. Furthermore, in both GMM cases, the Sargan-Hansen test of overidentifying restrictions accepts the validity of the instruments, the Difference Sargan accepts the validity of the extra restrictions, and there is no evidence of autocorrelation.

\section{E. Lessons for Poland}

58. The previous analysis could provide a reform road map for Poland. A strategy of improving labor market institutions cemented by an agreement between the social partners to ensure that workers do not bear the brunt of the adjustment could be both palatable and successful. Such a strategy would seem apt, since Poland's relatively poor labor market performance in recent years has been traced to institutional factors such as high tax wedges, generous social benefits, and rigid product markets (see OECD, 2006; Estevao, 2003;

\footnotetext{
${ }^{41}$ The measure of product market regulation hails from Conway and Nicoletti (2006) and focuses on the seven non-manufacturing sectors.
} 
Choueiri, 2005; Dalgic and Klingen, 2006). Figures 3 and 4 show Poland's position in relation to EU peers for each of these measures. This section discusses the various priorities in Poland, in light of the preceding evidence.

59. To start, tax wedges are quite high in Poland. The composite tax wedge on labor income is higher than in Poland's regional peers (Czech Republic, Hungary, and Slovak Republic), and Poland keeps company with the top echelon in the EU-15. This is especially pronounced for married couples, where Poland not only beats its regional peers, but shares the top spot in the EU with Sweden. Relative to other EU countries, Poland relies heavily on social security contributions in its tax system, especially those related to the funding of the disability welfare program. However, contributions - split evenly between employers and employees - have recently been lowered by 7 percentage points with knock-on effects for the tax wedge.

\section{Relatedly, expenditure on disability programs and early retirement pensions} remains elevated, fostering early withdrawal from the labor market. Incapacity-related expenditure reached 6 percent of GDP by the end of the 1990s. Since then, tighter eligibility conditions and an elimination of infinite-duration pensions pushed back spending to $3 \frac{1}{2}$ percent of GDP by 2003, with disability pensioners accounting for over 9 percent of the population over 15 (OECD, 2006). ${ }^{42}$ However, reforms in the general social security system (ZUS) were not matched by reforms in the farmers' special social security system (KRUS). ${ }^{43}$ Also, much of the gains on the disability front were eroded by a sharp increase in early retirement pensions, reaching 2 percent by $2003 .{ }^{44}$ Unemployment insurance itself is not so generous in Poland (spending on passive benefits is under 1 percent of GDP), but the disability and early retirement schemes clearly hinder job search and dampen employment.

\section{The government wage bill is not high by international standards, but wages are} growing strongly. As a percent of GDP, wage government consumption in Poland is similar to that in the regional new member states, as well as Ireland and the Netherlands, and below the EU average. But the ratio of public to total employment is higher than in Ireland and the Netherlands. At the same time, however, employment in the areas of public administration and defense have continued to increase (OECD, 2006). Also, wages are higher in the public

\footnotetext{
${ }^{42}$ The last entry in the OECD Social Expenditure Database.

${ }^{43}$ Although the agricultural sector accounts for 19 percent of employment, 25 percent of disability pensions are handled by KRUS (OECD, 2006). More generally, contributions are far lower to KRUS, creating an incentive to belong to this scheme, despite lower benefits.

${ }^{44}$ While normal pre-retirement pensions are available after 35 years for men and 30 years for women, this collapses to 15 years for those employed in "special conditions".
} 
sector than the private sector, and have risen twice as fast since 2000 , and the growth rate shows no signs of abating.

62. Relative to the EU, labor markets are not especially rigid in Poland, but there is scope for improvement. Although it scores a little better than the EU average, and is similar to its regional peers, it still lags behind Ireland in terms of EPLs. Also, Poland's rank relies heavily on its liberal rules governing temporary contracts, where it sits in the bottom echelon with Ireland, the United Kingdom, and the Netherlands. Permanent contracts tell a different story, where procedures required to dismiss workers and regulations governing collective dismissals push up the index (Poland is particularly strict on the latter). Still, arrangements pertaining to working hours are fairly flexible, and the requirements for justified dismissal and severance payments are not overly strict (OECD, 2006). EPLs do, however, make it impossible to fire a worker less than four years from the retirement age.

63. On the other hand, product market rigidity is acute in Poland. Based on the OECD economy-wide index, Poland stands out as the most regulated economy in the OECD in 2003, a position it also held in 1998. Breaking it down, Poland is deemed the most restrictive country in terms of state control, barriers to entrepreneurship (especially administrative burdens on startups), and barriers to trade and investment. On the other hand, competition law in Poland is relatively favorable, although competition problems persist in some sectors (including telecommunications). Although this index is by now a few years old, the World Bank's Doing Business survey for 2008 paints a similar picture, ranking Poland 74 out of 179 countries in terms of ease of doing business (only Greece was ranked lower in the EU27); this rank falls to 129 for starting a business and 156 for dealing with licenses. Moreover, Poland has actually slipped in rank from last year. Another index from the Fraser Institute shows Poland lagging behind not only the euro area, but the eight new members in its peer group, in terms of administrative burdens (Table 3). Others have noted that structural change came to a standstill in Poland at the dawn of the new century (Dalgic and Klingen, 2006).

64. By reforming along these lines, and emulating countries like Ireland in terms of labor market institutions, Poland could boost employment substantially. As a simple experiment, assume that Poland immediately jumped to the position of Ireland in $2003^{45}$ for the key variables - tax wedge, disability benefits, wage government consumption, degree of wage coordination/ centralization, employment protection legislation, and product market regulation. By taking the change in these variables as the distance between Ireland and Poland, the wage curve shift and the corresponding change in private sector employment can be calculated, while taking the dynamic effects into account. Of course, this experiment is

\footnotetext{
${ }^{45}$ The year 2003 is chosen as many of the data (including social benefits, EPLs, and product market regulation) end here.
} 
artificial on any number of grounds, and it runs into problems with extrapolation and the Lucas critique. It is premised on an instantaneous adjustment in all policy variables and a compartmentalized approach to policymaking that plays down the cohesive and encompassing social partnership framework. The cut-off date of 2003 - necessitated by data availability on social benefits - may make the gap between Ireland and Poland more stark than is actually the case, given a number of recent reforms. Also, focusing on aggregate labor market outcomes masks some core differences between the two countries-Ireland was able to boost female participation from a low starting point, an option not available to Poland where inactivity is concentrated among older workers.

\section{Despite the caveats, this simple numerical exercise signals sizeable effects. Using} the coefficients from the fixed effects estimation, it emerges that — upon an immediate move from Polish to Irish values of each variable in 2003 - the private sector employment rate would climb by about $91 / 2$ percentage points after three years, erasing 60 percent of the gap between the two countries. ${ }^{46}$ It is clear, therefore, that a large chunk of the difference between the two countries can be traced to institutional factors. If product markets are unreformed, the improvement falls to only 43 percent, while no action on EPLs reduces it to 54 percent. Once these variables are set, the relative contributions of the other variables can be calculated. Although the effects are nonlinear, insofar as the effect of the wage moderation variables on employment depends on the state of product and labor market flexibility, the overall contributions to closing the employment gap can be calculated as follows: product market regulation, 29 percent; tax wedge, 23 percent; the wage bargaining system, 15 percent; the government wage bill, 13 percent; employment protection legislation, 11 percent; and disability benefits, 9 percent. Clearly, product market regulation is paramount. The tax wedge effect arises from the huge difference between the two countries on that front, despite a relatively small coefficient. In contrast, while the size of the government wage bill does not differ much between Ireland and Poland, even small changes can have sizeable effects; this is in accord with previous research pointing to the importance of this particular channel (Alesina and others, 2002).

\section{Given these magnitudes and interactions, a good case can be made for reform on}

all fronts. In terms of importance, reducing the tax wedge and liberalizing product markets stand out, and these are precisely the areas where Poland lags the most. But reform is also needed in areas where Poland does relatively well. Although EPLs are not high by European standards, liberal labor markets are especially valuable during times of significant labor reallocation, such as when workers exit agriculture, and move between sectors in response to major structural change. And while the wage element of government consumption is low, the size of this effect on wage moderation suggests that policymakers should guard against

\footnotetext{
${ }^{46}$ Using instead the coefficients from the system GMM estimation, the reforms would remove 46 percent of the gap.
} 
undue public sector wage pressures. Aside from the boost to employment and potential growth, such a wage moderation strategy would also aid competitiveness. The nonKeynesian effects of fiscal contraction that emerge from the labor market channel tend to be large in new member states, showing up especially in exports (Rzonca and Cizkowicz, 2005). Looking at it from the other side, what matters for FDI seems to be the tax wedge, product market regulation, and EPLs - far more so than corporate tax rates (Hajkova and others, 2006). The benefits of a comprehensive and consistent reform strategy are manifold.

\section{F. Conclusion}

\section{Poland can learn from the experience of labor market reformers in Europe,} especially countries like Ireland and the Netherlands. Indeed, Poland in the early twentyfirst century shares a number of key traits with Ireland in the early 1980s, before the onset of reforms. Labor market outcomes - measured in terms of labor utilization, employment, and participation-look similar between these two periods. The backgrounds also overlap in numerous dimensions, as both experienced a long-term structural transformation out of agricultural employment and both had to recover from major macroeconomic shocks. At the same time, there were demographic overlaps as both countries experienced "baby booms" that entered the labor force at the right moment and both used emigration to dampen labor market pressures. The proximate cause of the superior employment performance in Ireland (and the Netherlands) was wage moderation, and these favorable demographic factors allowed the wage moderation to yield great rewards. Similarly, Poland is well placed to take advantage of a wage moderation strategy, provided it adopts the correct basket of reforms.

\section{The best recipe for Poland would combine liberal product and labor markets} with reductions in the tax wedge, disability benefits, and the size of the government wage bill. Delivering this package in the context of a centralized and coordinated agreement between the social partners would have the advantage of cementing the strategy in a coherent manner and creating sufficient "buy-in" by the different vested interests. It would also facilitate an internally consistent mixture of labor market, fiscal, and product market reforms that complement and reinforce each other. From this perspective, there is no obvious tradeoff between fiscal discipline and labor market reforms. Policies such as cutting tax wedges, disability benefits, and the government wage bill serve to boost labor supply, while low levels of product and labor market regulation allow such wage moderation to kindle vigorous employment growth, especially when the demographics are favorable. In other countries, this strategy allowed the high employment growth to boost revenue, which in turn paved the way for further tax cuts and continued wage moderation - a virtuous circle. Poland could benefit uniquely from such a strategy. 


\section{References}

Alesina, Alberto, and Silvia Ardagna, 1998, “Tales of Fiscal Adjustment," Economic Policy, Vol. 13, No. 27, pp 489-545.

Alesina, Alberto, Silvia Ardagna, Roberto Perotti, and Fabio Schiantarelli, 2002, "Fiscal Policy, Profits, and Investment,” American Economic Review, Vol. 92, No. 3, pp 571-589.

Alesina, Alberto, and Roberto Perotti, 1997, “The Welfare State and Competitiveness," American Economic Review, Vol. 87, No. 5, pp 921-939.

Annett, Anthony, 1998, “Openness and the Power of Public and Private Sector Unions in Developed Countries," unpublished, Columbia University, New York.

Annett, Anthony, 2007, “Lessons from Successful Labor Market Reformers in Europe,” IMF Policy Discussion Paper PDP/07/1 (Washington: International Monetary Fund).

Ardagna, Silvia, 2004, "Fiscal Stabilizations: When Do They Work and Why?,” European Economic Review, vol. 48, pp 1047-1074.

Arratibel, O., F. Heinz, R. Martin, M. Przybyla, L. Rawdanowicz, R. Serafini, and T. Zumer, 2007, "Determinants of Growth in the Central and Eastern European EU Member States-A Production Function Approach,” ECB Occasional Paper, No. 61 (Frankfurt: European Central Bank).

Baker, Dean, Andrew Glyn, David Howell, and John Schmitt, 2002, "Labor Market Institutions and Unemployment: A Critical Assessment of the Cross-Country Evidence," SCEPA Working Paper 2002-17, Schwartz Center for Economic Policy Analysis, New School University, New York.

Bakker, Bas B., and Ioannis Halikias, 1999, "Policy Reforms and Employment Creation," in C. Maxwell Watson, Bas B. Bakker, Jan Kees Martijn, and Ioannis Halikias [eds] The Netherlands: Transforming a Market Economy, Occasional Paper No. 81, International Monetary Fund, Washington DC.

Barrell, Ray, and Veronique Genre, 1999, "Employment Strategies for Europe: Lessons from Denmark and the Netherlands," National Institute Economic Review, No. 168, pp. 82-98.

Bassanini, Andrea, and Romain Duval, 2006, "Employment Patterns in OECD Countries: Reassessing the Role of Policies and Institutions," OECD Economics Department 
Working Paper No. 486 (Paris: Organization for Economic Cooperation and Development).

Berger, Helge, and Stephan Danninger, 2005, "Labor and Product Market Deregulation: Partial, Sequential, or Simultaneous Reform?,’ IMF Working Paper WP/05/227 (Washington: International Monetary Fund).

Blanchard, Olivier, 2005, "European Unemployment: the Evolution of Facts and Ideas," NBER Working Paper No. 11750.

Blanchard, Olivier, and Justin Wolfers, 2000, “The Role of Shocks and Institutions in the Rise of European Unemployment: the Aggregate Evidence,” Economic Journal, Vol. 110, No. 462, pp C1-33.

Bond, Stephen, 2002, "Dynamic Panel Data Models: A Guide to Micro Data Methods and Practice," Portuguese Economic Journal, Vol. 1, pp 141-162.

Calmfors, Lars, and John Driffill, 1988, "Bargaining Structure, Corporatism and Macroeconomic Performance,” Economic Policy, Vol. 6, pp 14-61.

Choueiri, Nada, 2005, “The Labor Market in Poland," in Poland: Selected Issues Paper, IMF Country Report No. 05/264 (Washington: International Monetary Fund).

Conway, Paul, and Giuseppe Nicoletti, 2006, "Product Market Regulation in NonManufacturing Sectors in OECD Countries: Measurement and Highlights," OECD Economics Department Working Paper, forthcoming (Paris: Organization for Economic Cooperation and Development).

Conway, Paul, Veronique Janod, and Giuseppe Nicoletti, 2005, "Product Market Regulation i OECD Countries: 1998 To 2003," OECD Economics Department Working Paper, No. 419 (Paris: Organization for Economic Cooperation and Development).

Dalgic, Engin, and Christoph Klingen, 2006, “Assessing the Flexibility of the Polish Economy,” in Poland: Selected Issues Paper, IMF Country Report No. 06/392 (Washington: International Monetary Fund).

Daveri, Francesco, and Guido Tabellini, 2000, "Unemployment, Growth, and Taxation in Industrial Countries,” Economic Policy, Vol. 15, No. 30, pp 47-104.

Decressin, Jörg, Marcello Estevao, Philip Gerson, and Christoph Klingon, 2001, "Job-Rich Growth in Europe," in France, Germany, Italy, and Spain: Selected Issues Paper, IMF Country Report No. 01/203 (Washington: International Monetary Fund). 
Duval, Romain, Jorgen Elmeskov, and Lukas Vogel, 2007, "Structural Policies and Economic Resilience to Shocks," OECD Economics Department Working Paper No. 567 (Paris: Organization for Economic Cooperation and Development).

Estevão, Marcello, 2003, "Structural and Cyclical Labor Market Changes in Poland," in Poland: Selected Issues Paper, IMF Country Report No. 03/188 (Washington: International Monetary Fund).

Estevão, Marcello, 2005, "Product Market Regulation and the Benefits of Wage Moderation,” IMF Working Paper WP/05/191 (Washington: International Monetary Fund).

Garibaldi, Pietro, and Paolo Mauro, 2002, “Anatomy of Employment Growth,” Economic Policy, No. 34, pp 69-113.

Hajkova, Dana, Giuseppe Nicoletti, Laura Vartia, and Kwang-Yeol Yoo, 2006, "Taxation, Business Environment, and FDI Location in OECD Countries," OECD Economics Department Working Paper No. 502 (Paris: Organization for Economic Cooperation and Development).

Hartog, Joop, 1999, "Whither Dutch Corporatism? Or: A Turbulent Tango for Market and State," Institute for Research on Poverty Discussion Paper No. 1197-99, University of Amsterdam.

Honohan, Patrick, and Brendan Walsh, 2002, "Catching Up With the Leaders: the Irish Hare," Brookings Papers on Economic Activity, No. 1, pp 1-77.

Hunt, Ben, 2004, "The Role of Social partnership Agreements in Ireland: Contributing to the Boom and Facilitating Adjustment to Sustainable Growth," in Ireland: Selected Issues Paper, IMF Country Report No. 04/349 (Washington: International Monetary Fund).

International Monetary Fund, 2003, "Unemployment and Labor Market Institutions: Why Reforms Pay Off,” in World Economic Outlook, April (Washington: International Monetary Fund).

Judson, Ruth A., and Ann L. Owen, 1999, "Estimating Dynamic Panel Data Models:

A Guide for Macroeconomists," Economics Letters, Vol. 65, pp. 9-15.

Nickell, Stephen, and Jan van Ours, 2000, "The Netherlands and the United Kingdom: A European Unemployment Miracle?," Economic Policy, Vol.15, No.30, pp. 135-180. 
Nickell, Stephen, Luca Nunziata, and Wolfgang Ochel, 2005, "Unemployment in the OECD Since the 1960s: What Do We Know?,” Economic Journal, Vol. 115, pp 1-27.

Nicoletti, Giuseppe, and Stefano Scarpetta, 2005, "Product Market Reforms and Employment in OECD Countries," OECD Economics Department Working Paper No. 472 (Paris: Organization for Economic Cooperation and Development).

Organization for Economic Cooperation and Development, 2004, "Employment Protection Regulation and Labour Market Performance," in Employment Outlook, Paris: OECD.

Rzonca, Andrzej, and Piotr Cizkowicz, 2005, "Non-Keynesian Effects of Fiscal Contraction in New Member States," ECB Working Paper, No. 519 (Frankfurt: European Central Bank).

Organization for Economic Cooperation and Development, 2006, OECD Economic Survey of Poland, Paris: OECD.

Soskice, David, 1990, "Wage Determination: The Changing Role of Institutions in Advanced Industrialized Countries," Oxford Review of Economic Policy, Vol. 6, No. 4, pp 36-61.

Walsh, Brendan, 2003, "When Unemployment Disappears: Ireland in the 1990s," CESIFO Working Paper No. 856. 
Figure II.1. Employment in the European Union, 1980-2006 1/ 2/
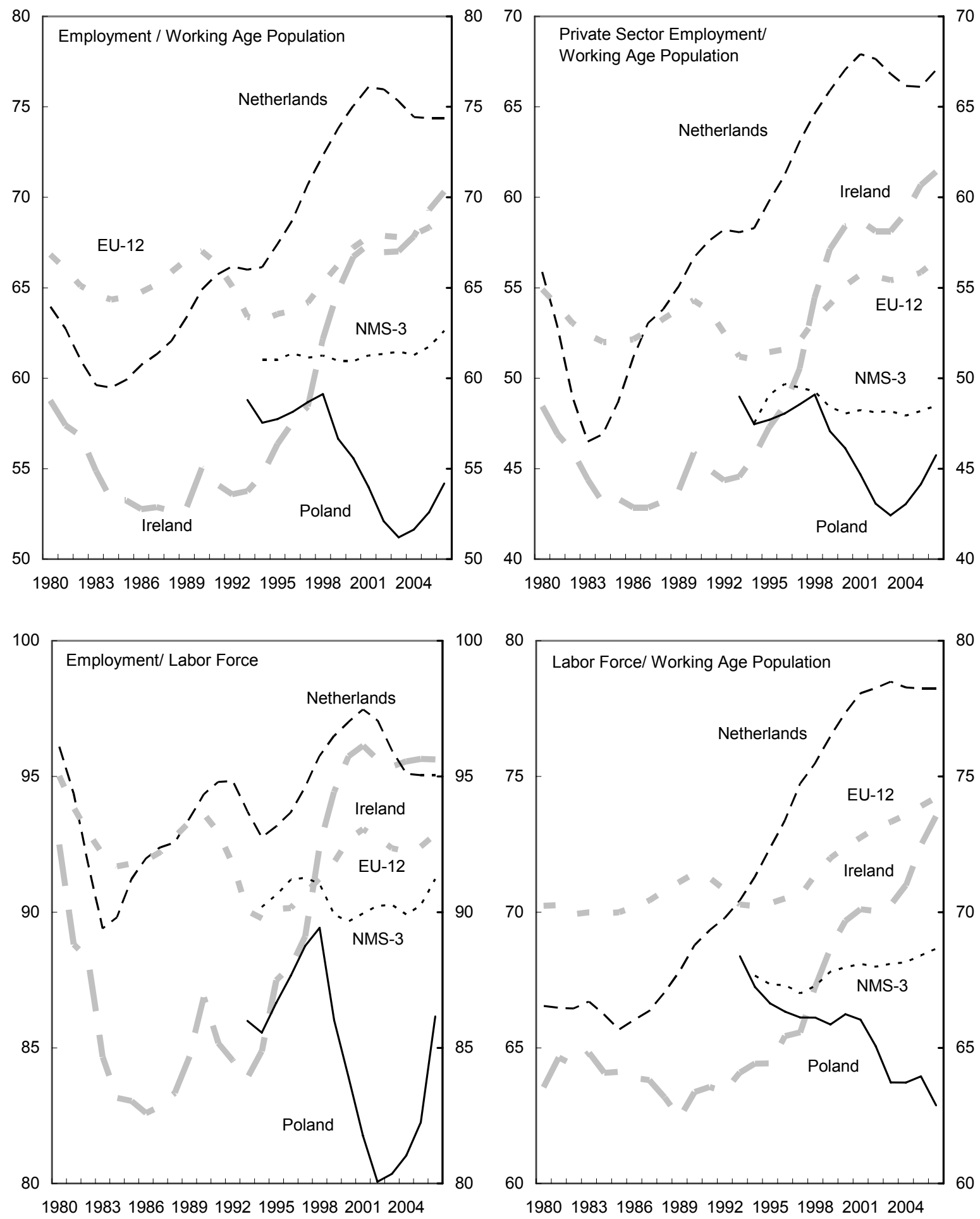

Source: OECD Economic Outlook and OECD Analytical Database.

1/ EU-12 refers to EU-15 excluding Ireland, Netherlands, and Luxembourg.

2/ NMS-3 includes Czech Republic, Hungary, and Slovak Republic. 
Figure II.2. Wage Moderation in the European Union, 1980-2006 1/

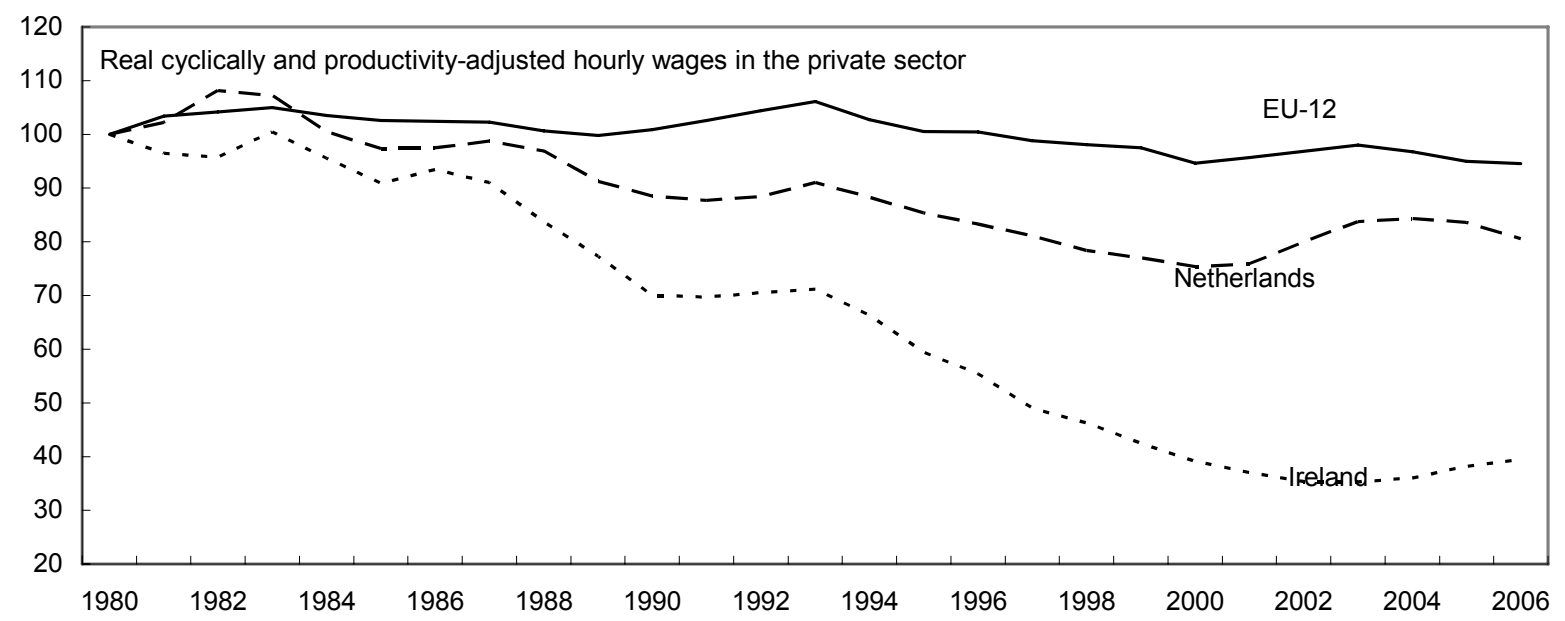

Source: Authors calculations based on OECD Economic Outlook and OECD Analytical Database.

1/ EU-12 refers to EU-15 excluding Ireland, Netherlands, and Luxembourg. 
Figure II.3. Fiscal Effects on the Labor Market, 1980-2006 1/ 2/
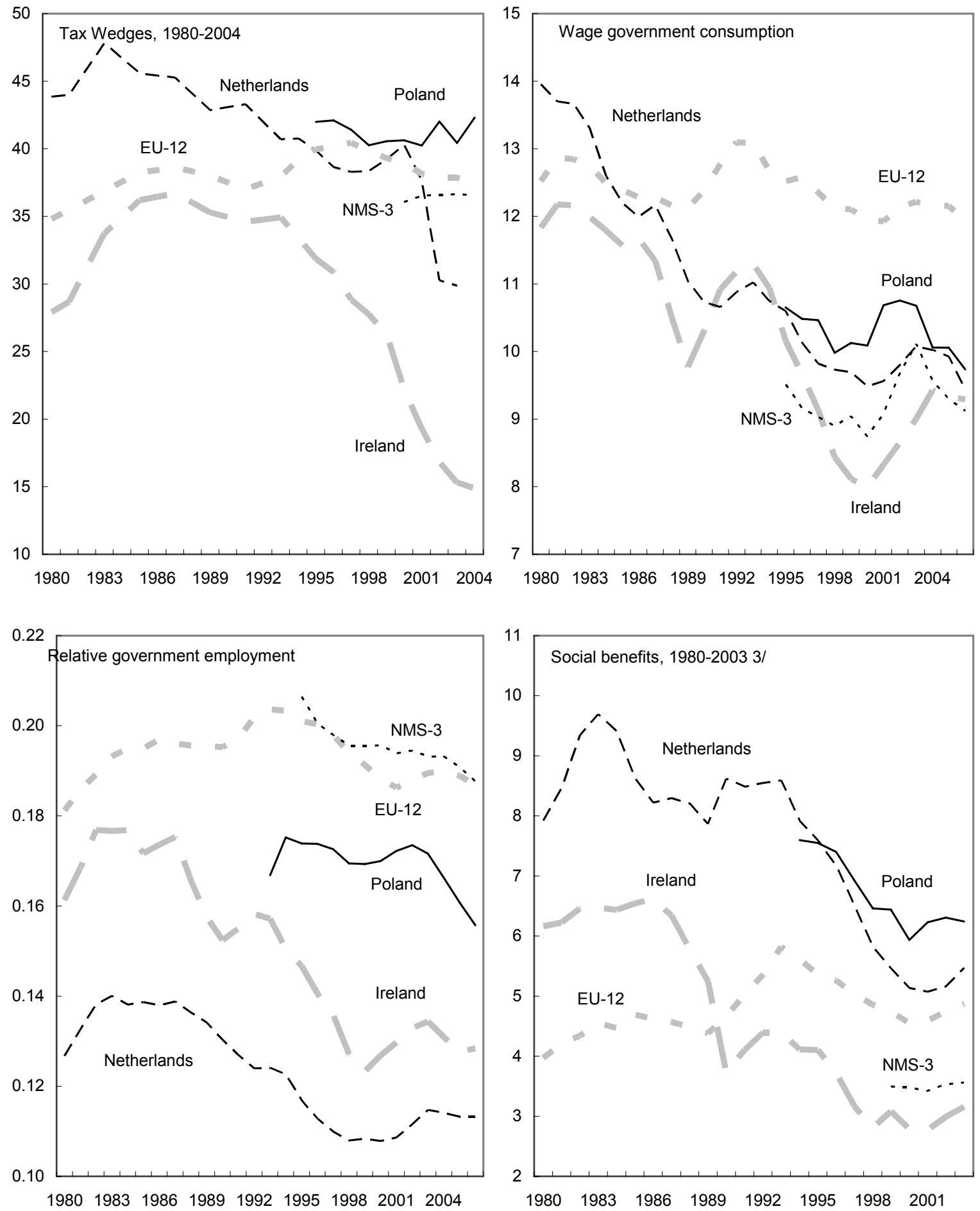

Source: OECD Economic Outlook, OECD Analytical Database, OECD Taxing Wages Database, and OECD Social Expenditure Database.

1/ EU-12 refers to EU-15 excluding Ireland, Netherlands, and Luxembourg.

2/ NMS-3 includes Czech Republic, Hungary, and Slovak Republic.

$3 /$ Unemployment benefits, incapacity-related benefits, and early retirement pensions. 
Figure II.4. Labor and Product Market Regulation, 2003
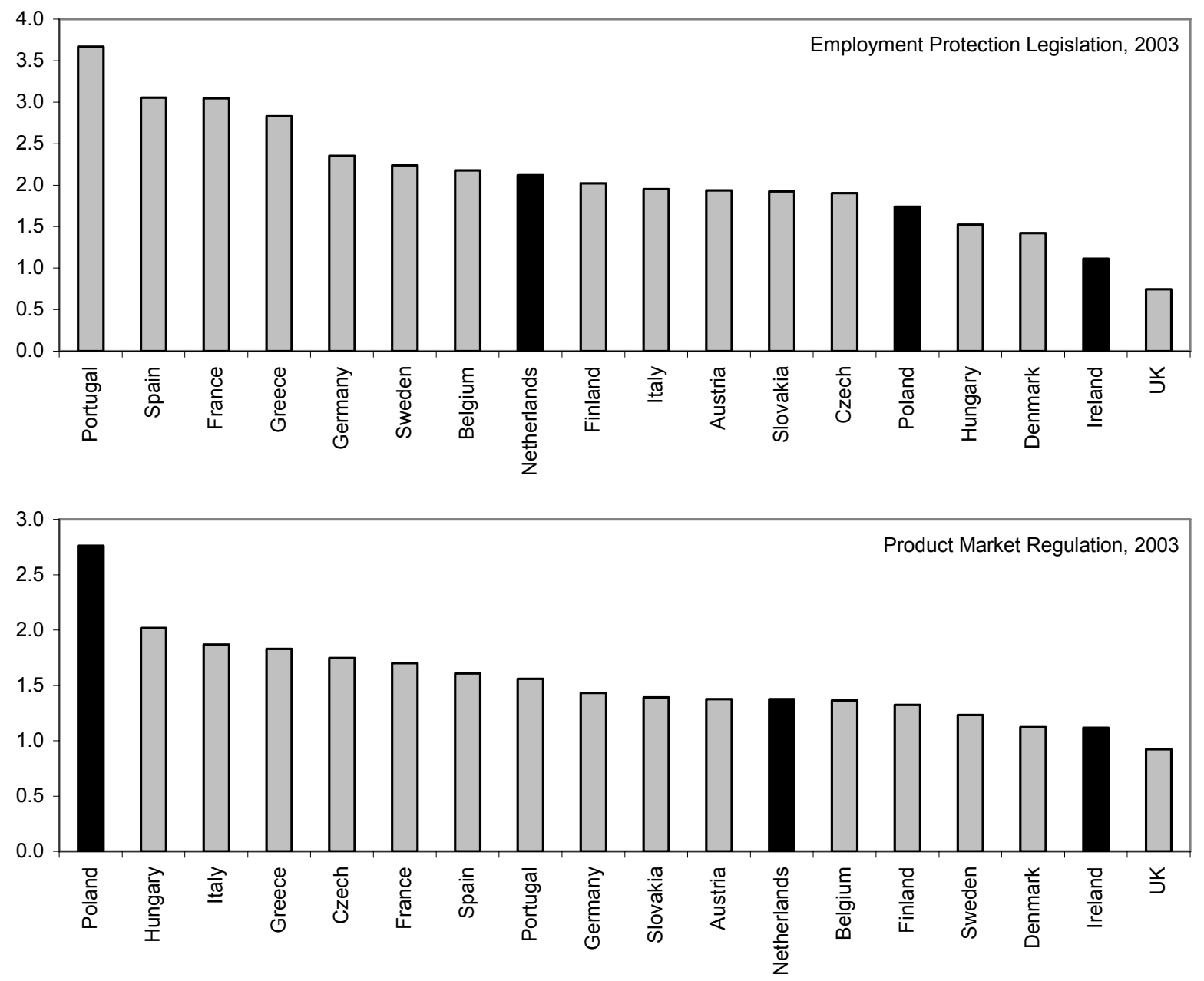

Source: OECD (2004); Conway and others (2005). 
Table II.1: Estimating the Policy Determinants of Wage Moderation (Dependent variable: change in cyclically and productivity-adjusted real hourly wage)

\begin{tabular}{|c|c|c|c|c|c|c|}
\hline & $\begin{array}{l}(1) \\
\text { Pooled } \\
\text { OLS }\end{array}$ & $\begin{array}{c}(2) \\
\text { Fixed } \\
\text { effects }\end{array}$ & $\begin{array}{c}(3) \\
\text { Fixed } \\
\text { effects }\end{array}$ & $\begin{array}{c}(4) \\
\text { Fixed } \\
\text { effects }\end{array}$ & $\begin{array}{c}\text { (5) } \\
\text { FD- } \\
\text { GMM }\end{array}$ & $\begin{array}{c}(6) \\
\text { System- } \\
\text { GMM }\end{array}$ \\
\hline $\begin{array}{l}\text { Lagged change in cyclically and productivity-adjusted } \\
\text { real hourly wage }\end{array}$ & $\begin{array}{l}0.32^{* * *} \\
(0.05)\end{array}$ & $\begin{array}{l}0.28^{* * *} \\
(0.06)\end{array}$ & $\begin{array}{l}0.31^{* * *} \\
(0.05)\end{array}$ & $\begin{array}{l}0.27^{* * *} \\
(0.07)\end{array}$ & $\begin{array}{l}0.26^{* * *} \\
(0.05)\end{array}$ & $\begin{array}{l}0.29^{* * *} \\
(0.04)\end{array}$ \\
\hline Change in tax wedge & $\begin{array}{l}0.32^{*} \\
(0.15)\end{array}$ & $\begin{array}{l}0.28^{*} \\
(0.14)\end{array}$ & $\begin{array}{l}0.24 \\
(0.16)\end{array}$ & $\begin{array}{l}0.25^{\star} \\
(0.14)\end{array}$ & $\begin{array}{l}0.20^{*} \\
(0.11)\end{array}$ & $\begin{array}{l}0.22^{* *} \\
(0.10)\end{array}$ \\
\hline Change in incapacity-related expenditure & $\begin{array}{l}1.67^{\star *} \\
(0.78)\end{array}$ & $\begin{array}{l}1.81^{\star * *} \\
(0.81)\end{array}$ & $\begin{array}{l}2.61^{* *} \\
(1.08)\end{array}$ & $\begin{array}{l}1.22 \\
(0.74)\end{array}$ & $\begin{array}{l}1.11^{*} \\
(0.66)\end{array}$ & $\begin{array}{l}1.06^{*} \\
(0.61)\end{array}$ \\
\hline Change in government wage bill & $\begin{array}{l}2.40^{* * *} \\
(0.65)\end{array}$ & $\begin{array}{l}2.57^{* * *} \\
(0.67)\end{array}$ & & $\begin{array}{l}2.15^{\star \star *} \\
(0.64)\end{array}$ & $\begin{array}{l}2.17^{* * *} \\
(0.36)\end{array}$ & $\begin{array}{l}2.45^{\star * *} \\
(0.32)\end{array}$ \\
\hline Change in relative government employment & & & $\begin{array}{l}0.81^{* *} \\
(0.35)\end{array}$ & & & \\
\hline Change in real government wage rate & & & $\begin{array}{l}0.19^{*} \\
(0.09)\end{array}$ & & & \\
\hline Change in bargaining centralization/ coordination & & & & $\begin{array}{l}-1.40^{\star *} \\
(0.69)\end{array}$ & $\begin{array}{l}-1.32^{\star *} \\
(0.64)\end{array}$ & $\begin{array}{l}-1.07^{*} \\
(0.61)\end{array}$ \\
\hline Year dummies & Yes & Yes & Yes & Yes & Yes & Yes \\
\hline $\mathrm{N}$ & 295 & 295 & 291 & 273 & 260 & 273 \\
\hline $\mathrm{R} 2$ & 0.48 & 0.48 & 0.43 & 0.53 & .. & .. \\
\hline Sargan-Hansen test of overidentifying restrictions ( $p$-value) & .. & .. & .. & .. & 0.01 & 0.70 \\
\hline Test for first order autocorrelation ( $p$-value) & .. & .. & .. & .. & -6.39 & -5.45 \\
\hline Test of second order autocorrelation ( $p$-value) & .. & .. & .. & .. & -2.07 & -1.83 \\
\hline Difference Sargan ( $p$-value) & .. & .. & .. & .. & .. & 1.00 \\
\hline
\end{tabular}

Source: Staff calculations based on OECD data.

Note: Standard errors in parentheses. ${ }^{* * *},{ }^{* *}$, and ${ }^{*}$ denote statistical significance at the 1 percent, 5 percent, and 10 percent levels respectively. 
Table II.2: Estimating the Effect of Wage Curve Shifts on Employment

(Dependent variable: change in ratio of private sector employment to working age population)

\begin{tabular}{|c|c|c|c|c|}
\hline & $\begin{array}{c}(1) \\
\text { Pooled OLS }\end{array}$ & $\begin{array}{c}(2) \\
\text { Fixed effects }\end{array}$ & $\begin{array}{c}(3) \\
\text { FD-GMM }\end{array}$ & $\begin{array}{c}(4) \\
\text { System-GMM }\end{array}$ \\
\hline First lag of change in private sector employment & $\begin{array}{l}0.65^{\star \star *} \\
(0.11)\end{array}$ & $\begin{array}{l}0.56^{* * *} \\
(0.10)\end{array}$ & $\begin{array}{l}0.56^{* * *} \\
(0.06)\end{array}$ & $\begin{array}{l}0.59 * * * \\
(0.04)\end{array}$ \\
\hline Second lag of change in private sector employment & $\begin{array}{l}-0.06 \\
(0.10)\end{array}$ & $\begin{array}{l}-0.07 \\
(0.09)\end{array}$ & $\begin{array}{l}-0.07 \\
(0.07)\end{array}$ & $\begin{array}{l}-0.07 \\
(0.05)\end{array}$ \\
\hline Third lag of change in private sector employment & $\begin{array}{l}-0.07 \\
(0.07)\end{array}$ & $\begin{array}{l}-0.14^{*} \\
(0.07)\end{array}$ & $\begin{array}{l}-0.14^{* * *} \\
(0.06)\end{array}$ & $\begin{array}{l}-0.13^{* * *} \\
(0.04)\end{array}$ \\
\hline Change in cyclically and productivity-adjusted real hourly wage & $\begin{array}{l}-0.26^{* * *} \\
(0.08)\end{array}$ & $\begin{array}{l}-0.32^{* \star *} \\
(0.08)\end{array}$ & $\begin{array}{l}-0.32^{* * *} \\
(0.06)\end{array}$ & $\begin{array}{l}-0.26 * * * \\
(0.05)\end{array}$ \\
\hline Index of product market regulation & $\begin{array}{l}-0.005 \\
(0.05)\end{array}$ & $\begin{array}{l}0.17 \\
(0.10)\end{array}$ & $\begin{array}{l}0.17 \\
(0.12)\end{array}$ & $\begin{array}{l}0.07 \\
(0.06)\end{array}$ \\
\hline Index of employment protection legislation & $\begin{array}{l}0.05 \\
(0.06)\end{array}$ & $\begin{array}{l}-0.05 \\
(0.14)\end{array}$ & $\begin{array}{l}-0.06 \\
(0.16)\end{array}$ & $\begin{array}{l}0.01 \\
(0.06)\end{array}$ \\
\hline $\begin{array}{l}\text { Change in cyclically and productivity-adjusted real hourly wage } \\
\text { * Index of product market regulation }\end{array}$ & $\begin{array}{l}0.02 \\
(0.02)\end{array}$ & $\begin{array}{l}0.04^{*} \\
(0.02)\end{array}$ & $\begin{array}{l}0.04^{* * *} \\
(0.01)\end{array}$ & $\begin{array}{l}0.02^{* *} \\
(0.01)\end{array}$ \\
\hline $\begin{array}{l}\text { Change in cyclically and productivity-adjusted real hourly wage } \\
\text { * Index of Index of employment protection legislation }\end{array}$ & $\begin{array}{l}0.04^{* *} \\
(0.02)\end{array}$ & $\begin{array}{l}0.04^{* *} \\
(0.01)\end{array}$ & $\begin{array}{l}0.04^{* *} \\
(0.02)\end{array}$ & $\begin{array}{l}0.04^{* * *} \\
(0.01)\end{array}$ \\
\hline Year dummies & Yes & Yes & Yes & Yes \\
\hline $\mathrm{N}$ & 266 & 266 & 252 & 266 \\
\hline $\mathrm{R} 2$ & 0.68 & 0.66 & .. &.. \\
\hline Sargan-Hansen test of overidentifying restrictions ( $p$-value) &.. & .. & 0.27 & 0.16 \\
\hline Test for first order autocorrelation &.. & .. & -11.63 & -8.27 \\
\hline Test of second order autocorrelation & .. & .. & 0.66 & 0.37 \\
\hline Difference Sargan ( $p$-value) &.. & .. & .. & 0.20 \\
\hline
\end{tabular}

Source: Staff calculations based on OECD data.

Note: Standard errors in parentheses. ${ }^{* * *}$, ${ }^{* *}$, and ${ }^{*}$ denote statistical significance at the 1 percent, 5 percent, and 10 percent levels respectively. 
Table II.3. Fraser Institute Indicators of Administrative Burden in New Member States, 2004

Price Burden of Time with Starting a Irregular Business Regulation controls regulations government new payments regulations bureaucracy business

\begin{tabular}{|c|c|c|c|c|c|c|c|}
\hline Czech Republic & 7.0 & 3.1 & 8.8 & 5.0 & 6.3 & 6.0 & 6.4 \\
\hline Estonia & 6.0 & 5.2 & 7.3 & 7.1 & 7.8 & 6.7 & 7.3 \\
\hline Hungary & 6.0 & 3.2 & 9.7 & 6.5 & 7.3 & 6.6 & 7.3 \\
\hline Latvia & 6.0 & 3.8 & 6.9 & 6.8 & 5.8 & 5.9 & 6.7 \\
\hline Lithuania & 6.0 & 3.1 & 6.3 & 5.8 & 6.9 & 5.6 & 6.4 \\
\hline Poland & 3.0 & 2.8 & 7.0 & 5.4 & 5.5 & 4.8 & 5.9 \\
\hline Slovakia & 6.0 & 2.9 & 7.4 & 6.8 & 6.3 & 5.9 & 6.8 \\
\hline Slovenia & 4.0 & 2.9 & 6.3 & 4.9 & 7.8 & 5.2 & 6.3 \\
\hline EU8 & 5.5 & 3.4 & 7.5 & 6.0 & 6.7 & 5.8 & 6.6 \\
\hline Euro area & 6.3 & 3.5 & 7.3 & 6.2 & 8.0 & 6.3 & 6.5 \\
\hline
\end{tabular}

Source: Fraser Institute, from Arratibel and others (2007).

Index values between 1 and 10, with higher values indicating better regulations. 